\title{
Tectonosedimentary evolution of the Coastal Cordillera and Central Depression of south-Central Chile $\left(36^{\circ} 30^{\prime}-42^{\circ} \mathrm{S}\right)$
}

\author{
A. Encinas ${ }^{\text {a, }}$, L. Sagripanti ${ }^{b}$, M.P. Rodríguez ${ }^{c}$, D. Orts ${ }^{\text {d,e }}$, A. Anavalón ${ }^{\mathrm{a}}$, P. Giroux ${ }^{\mathrm{a}}$, J. Otero ${ }^{\mathrm{f}}$, \\ A. Echaurren ${ }^{\text {g }}$, P. Zambrano ${ }^{\text {h }}$, V. Valencia ${ }^{\mathrm{i}}$ \\ a Universidad de Concepción, Facultad de Ciencias Químicas, Departamento de Ciencias de la Tierra, Concepción, Chile \\ ${ }^{\mathrm{b}}$ Universidad de Buenos Aires, CONICET, Instituto de Estudios Andinos "Don Pablo Groeber"-Facultad de Ciencias Exactas y Naturales, Departamento de Geología, \\ Buenos Aires, Argentina \\ ${ }^{\mathrm{c}}$ Universidad de Atacama, Departamento de Geología, Copiapó, Chile \\ ' Universidad Nacional de Río Negro, Instituto de Investigación en Paleobiología y Geología, General Roca, Río Negro, Argentina \\ e Instituto de Investigación en Paleobiología y Geología (IIPG), CONICET, Av. J. A. Roca 1242, 8332 General Roca, Río Negro, Argentina \\ ${ }^{\mathrm{f}}$ Universidad Austral de Chile, Instituto de Ciencias de la Tierra, Valdivia, Chile \\ ${ }^{g}$ Instituto Argentino de Nivología, Glaciología y Ciencias Ambientales (IANIGLA), Centro Científico Tecnológico CONICET, Mendoza, Argentina \\ ${ }^{\mathrm{h}}$ Universidad Andres Bello, Facultad de Ingeniería, Geología, Autopista Talcahuano, 7100 Concepción, Chile \\ ${ }^{\mathrm{i}}$ Washington State University, School of the Environment, Pullman, USA
}

\section{A R T I C L E I N F O}

\section{Keywords:}

Forearc

Coastal Cordillera

Central Depression

West Andean Thrust

South-central Chile

\begin{abstract}
A B S T R A C T
The forearc of south-central Chile $\left(36^{\circ} 30^{\prime}-42^{\circ} \mathrm{S}\right)$ is characterized by the presence of a Coastal Cordillera and a low lying area known as the Central Depression. The origin of these morphostructural units has been largely debated. They have been ascribed to different ages between the Cretaceous and the Pliocene, and tectonic causes that involve extensional or contractional deformation and have been related to Andean evolution or accretionary processes in the forearc. To investigate the geologic evolution of the Coastal Cordillera and Central Depression in the cited area, we based on stratigraphy, sedimentology, geochronology (U-Pb, LA-ICP-MS), structural geology, and geomorphology. Our studies, which are based on our own data and a thorough bibliographic review, indicate the following sequence of events in the tectono-sedimentary evolution of the forearc of south-central Chile during the late Cenozoic. The area was subjected to extensional tectonics caused by slab rollback during the Oligoceneearly Miocene, resulting in the genesis of a series of basins filled with volcanic, continental, and marine deposits that extended from the present Chilean coast to the retroac. The extensional basins were tectonically inverted during the late Early-Late Miocene, and most of the forearc became a positive relief that was subjected to fluvial erosion. The West Andean Thrust, a major reverse west verging fault in the limit between the Central Depression and the Andean Cordillera, caused significant uplift of the western flank of the Andes. This triggered flexural subsidence and the accumulation of coarse-grained deposits in the forearc during the Pliocene-Pleistocene. The sudden increase of sediment flux to the trench during this period caused a change from non-accretion or subduction erosion to accretion in the margin of south-central Chile. Progressive growth of the accretionary wedge gave birth to a forearc high, the Coastal Cordillera, which was uplifted in the last $2 \mathrm{Ma}$. Some forearc areas placed above subducted oceanic fracture zones did not experience uplift during this period due to the significant transport of fluid that inhibited the deformation of the accretionary wedge. Our studies show that the late Cenozoic tectono-sedimentary evolution of the forearc in the study area is complex and involves different processes related to Andean evolution in the first stage and accretionary processes acting exclusively in the forearc in a second stage. The Coastal Cordillera and the Central Depression of south-central Chile were developed in the last $2 \mathrm{Ma}$ and are much younger than classically considered.
\end{abstract}

\footnotetext{
* Corresponding author.

E-mail address: aencinas@udec.cl (A. Encinas).
} 


\section{Introduction}

Convergent margins are classified as erosive or accretionary depending on their material-transfer modes (e.g., Von Huene and Scholl, 1991; Clift and Vannucchi, 2004; Kukowski and Oncken, 2006). Erosive margins form in areas where trench sediment thickness is less than $1 \mathrm{~km}$ and convergence rates exceed $6.0 \mathrm{~cm} / \mathrm{a}$. They are characterized by trench retreat and forearc subsidence triggered by subduction erosion (Von Huene and Scholl, 1991; Clift and Vannucchi, 2004). Accretionary margins develop in regions where trench sediment thickness exceeds 1 $\mathrm{km}$, and the rate of ortogonal convergence is $<7.6 \mathrm{~cm} / \mathrm{a}$ (Clift and Vannucchi, 2004). In accretionary margins, trench sediment is frontally obducted to the upper plate forming an accretionary prism, which can be described as a particular case of a submarine fold-and-thrust-belt (Clift and Vannucchi, 2004; Maksymowicz, 2015). The accreted material tends to accumulate in front of and beneath the accretionary prism by frontal accretion and underplating, forming a wedge-shaped body that grows with time (Cloos and Shreve, 1988; Von Huene and Scholl, 1991; Brandon et al., 1998; Clift and Vannucchi, 2004). Forearc basins typically form between the accretionary wedge (also known as subduction complex), which acts as a dam to pond sediment, and the arc (Dickinson and Seely, 1979; Dickinson, 1995). Forearc basins are subjected to little contractional deformation since this is mostly concentrated in the accretionary wedge (Dickinson, 1995). Sediment in these basins is typically derived from the arc area, reaches thicknesses between 1000 to $>10.000 \mathrm{~m}$, and accumulate at rates that range from $25 \mathrm{~m} / \mathrm{my}$ to more than $250 \mathrm{~m} / \mathrm{my}$. Subsidence in forearc basins is thought to be caused principally by the growing tectonic load of the accretionary wedge (Dickinson, 1995). As the subduction complex grows, forearc basins typically shoal with time, evolving from turbiditic to shallow marine and even continental deposition (Dickinson and Seely, 1979; Dickinson, 1995). The morphology of accretionary wedges and forearc basins can adopt different configurations determined by the elevation of the trenchslope break and the sedimentation rate. This configuration typically varies with time (see Fig. 6 in Dickinson and Seely, 1979).

Coastal Cordilleras or Coast Ranges are typically considered as uplifted, subaerially exposed, forearc highs (e.g., Brandon et al., 1998). They are characteristic of mature continental convergent margins classified by Dickinson and Seely (1979) as ridged forearcs. The best-studied Coastal Cordilleras occur along the Cascadia margin (Brandon et al., 1998, and references therein). Other well-known examples are Kodiak Island in the eastern Aleutian margin, Shikoku of the southeast Japan margin, the Island of Crete of the Hellenic margin, southern Iraq and western Pakistan of the Makran margin, and northeast New Zealand of the Hikurangi margin (Brandon et al., 1998 and references therein). Coastal Cordilleras run parallel to the trench, and they are typically flanked by a forearc depression located between them and the volcanic arc (Brandon et al., 1998). Most authors ascribe uplift and emersion of Coastal Cordilleras to the thickening of an accretionary wedge (e.g., Brandon et al., 1998; Clift and Vannucchi, 2004).

The Chilean margin presents a Coastal Cordillera that runs parallel to the trench along most of its length. Between this range and the Andean Cordillera there is a low lying area, typically interpreted as a forearc basin, known as the Central Depression (e.g., Jordan et al., 1983; Horton, 2018). Several studies have been carried out in the tectonostratigraphic evolution of the Andean Cordillera (e.g., Mpodozis and Ramos, 1989; Charrier et al., 2007; Armijo et al., 2010; Farías et al., 2010; Giambiagi et al., 2014). Fewer works have been performed in the genesis of the Coastal Cordillera and the Central Depression, most of them being carried out in central and south-central Chile $\left(\sim 33^{\circ}-42^{\circ} \mathrm{S}\right)$ (e.g., Brüggen, 1950; Farías et al., 2008b; Rehak et al., 2008; Melnick et al., 2009). As a consequence, the causes and timing for the development of these morphotectonic units are debated. The genesis of the Coastal Cordillera and the Central Depression at the cited latitudes has been assigned to the Cretaceous (Gana and Wall, 1997), Late OligoceneEarly Miocene (Muñoz et al., 2000), Late Miocene (Farías et al., 2008b), or Pliocene (Brüggen, 1950; Melnick et al., 2009). The geologic evolution of these physiographic units has been related to very different causes including the uplift of the entire margin and the creation of the Central Depression by downwarping triggered by extensional tectonics (Brüggen, 1950), or by differential fluvial erosion (Farías et al., 2006; Farías et al., 2008b); to basal accretion driving the uplift of the Coastal Cordillera (Rehak et al., 2008); to the trenchward growth of the Andes that generated a foreland basin by orogenic loading (the Central Depression) and a fore-bulge (the Coastal Cordillera) in the forearc area (Armijo et al., 2010); or to the widening of the crustal root caused by Andean shortening that triggered passive surface uplift in the Coastal Cordillera by isostatic rebound (Giambiagi et al., 2014) (see chapter 4.3 for more details). Also not well understood is the origin of the latitudinal differences in elevation of these morphostructural units; the Coastal Cordillera is considerably low or even absent in some areas of the Chilean margin, whereas junction ridges connecting the Coastal and Andean Cordilleras characterize some parts of the Central Depression (e. g., Rehak et al., 2008; Farías et al., 2008b).

The cited studies show the incertitude in the genesis, timing, and latitudinal variability of the Coastal Cordillera and Central Depression. It is noteworthy that some authors relate the tectono-stratigraphic evolution of these morphostructural units to the development of the Andean Cordillera (e.g., Armijo et al., 2010; Giambiagi et al., 2014) whereas others ascribe their origin to accretionary processes occurring exclusively in the forearc (e.g., Lohrmann et al., 2006; Rehak et al., 2008; Melnick et al., 2009). Also debated is the relationship of the Coastal Cordillera and Central Depression genesis with extensional (Brüggen, 1950; Muñoz et al., 2000), or contractional deformation (Rehak et al., 2008; Melnick et al., 2009), passive uplift (e.g., Giambiagi et al., 2014), or even differential erosion (Farías et al., 2006; Farías et al., 2008b).

The forearc of south-central Chile $\left(36^{\circ} 30^{\prime}-42^{\circ}\right.$ S. Fig. 1$)$ is a key area to understand the genesis of these morphostructural units because there are widespread exposures of marine and continental late Cenozoic deposits that can help to constraint their evolution (Fig. 2). To investigate the tectono-sedimentary development of the.

Coastal Cordillera and Central Depression in this area, we based our study on stratigraphy, sedimentology, geochronology (U-Pb, LA-ICPMS), structural geology, and geomorphology. Based on our findings and previous studies in this region, we explore the causes of the geologic evolution and latitudinal variability of these morphostructural units. Our studies reveal that their development is complex and related to different factors that varied with time. In particular, we show that tectonic processes in the Andean Cordillera had an important influence on the geological evolution of the forearc.

\section{Review}

\subsection{Geologic setting}

The Chilean margin has been an ongoing subduction area, probably since Paleozoic times (Oliveros et al., 2019). In south-central Chile, the oceanic Nazca plate subduces under the South American continent at a convergence rate of $66 \mathrm{~mm} / \mathrm{a}$, with an azimuth of about N78 ${ }^{\circ} \mathrm{W}$ (Kendrick et al., 2003). There are two major bathymetric features of the oceanic plate along the Chilean margin: 1) the Chile Rise, an active spreading center that forms a triple junction between the Nazca, South American, and Antarctic plates at $46^{\circ} 30^{\prime} \mathrm{S}$, and 2) the Juan Fernández Ridge, a hot spot seamount chain intersecting the margin at $\sim 33^{\circ} \mathrm{S}$. In our study area $\left(36^{\circ} 30^{\prime}-42^{\circ} \mathrm{S}\right)$, major discontinuities of the Nazca.

Plate are the Mocha fracture zone (FZ) at $38^{\circ} \mathrm{S}$, which is oblique to the margin, and the almost parallel to the convergence vector $\left(\sim \mathrm{N78}{ }^{\circ} \mathrm{E}\right)$ Valdivia FZ at $40^{\circ} \mathrm{S}$, and Chiloé $\mathrm{FZ}$ at $42^{\circ} \mathrm{S}$ (Somoza, 1998; Rehak et al., 2008) (Fig. 1).

Three morphostructural units parallel to the trench characterize most of the Chilean margin; from west to east, these are the Coastal 


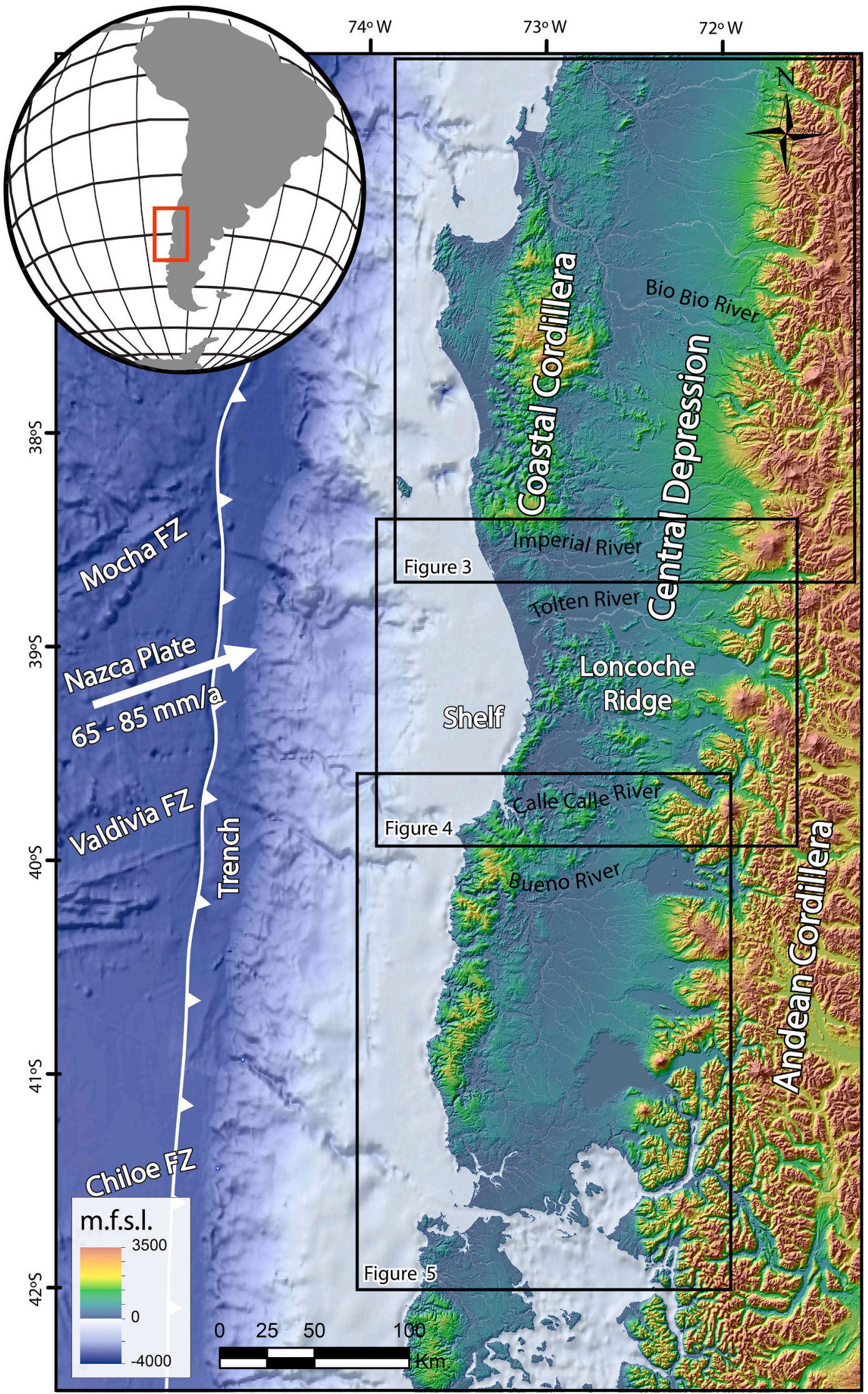

Fig. 1. Digital elevation model of the study area showing the location of the Coastal Cordillera, the Central Depression, the western flank of the Andean Cordillera, the Loncoche Ridge, the trench axis, and the main oceanic fracture zones. Note Rivers born in the Andean Cordillera that traverse the entire forearc (Bío-Bío, Imperial, Toltén, Calle- Calle, and Bueno rivers). Insets show the location of Figs. 3, 4, and 5. 


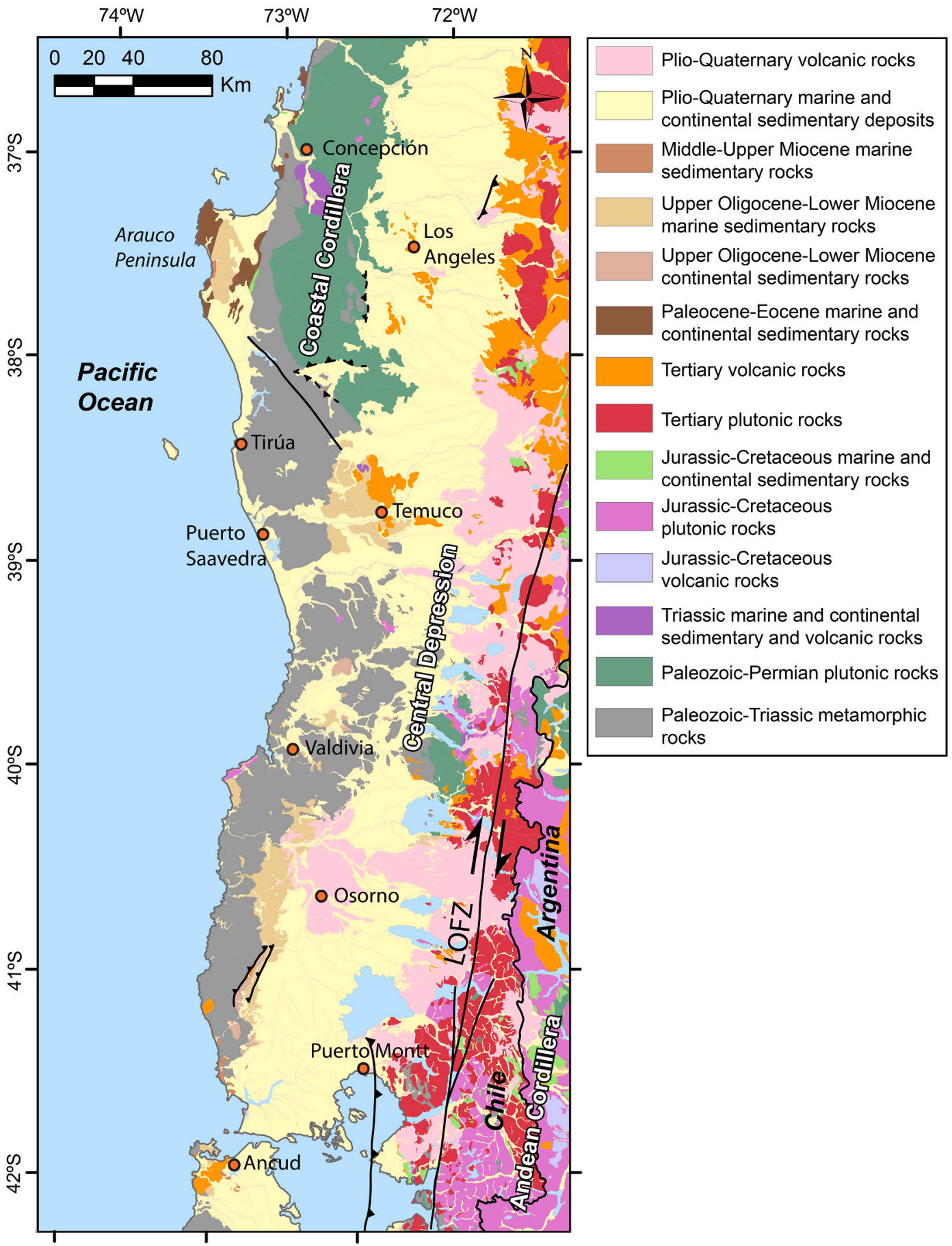

Fig. 2. Geological map of the study area with the main tectonic structures. Modified from Sernagemin, 2003; Rehak et al., 2008 ; and Encinas et al., 2012.

Cordillera, the Central Depression, and.

the Andean Cordillera (Fig. 1). Instead, a continuous rise in mean elevation along a west-east direction, and the absence of a Central Depression, characterize the segment between $\sim 27^{\circ}$ and $33^{\circ} \mathrm{S}$ (Rodríguez et al., 2014). The subduction of the aseismic Juan Fernandez Ridge caused the diminution of the subduction angle in this area (Charrier et al., 2007 and references therein). The lack of the Central Depression between $\sim 27^{\circ}$ and $33^{\circ} \mathrm{S}$ has been attributed to the higher degree of intraplate coupling produced by the flat-slab subduction (Charrier et al., 2007). The Central Depression is also absent south of the triple junction at $46^{\circ} 30^{\prime} \mathrm{S}$ (Charrier et al., 2007), which is probably caused by the subduction of the Chile Rise.

\subsubsection{Forearc: Costal Cordillera and Central Depression}

In the study area $\left(36^{\circ} 30^{\prime}-42^{\circ} \mathrm{S}\right)$, the Coastal Cordillera and the basement of the Central Depresssion is principally composed of Upper Paleozoic-Triassic metamorphic rocks and Carboniferous-Permian and Cretaceous plutonic rocks (Sernageomin, 1998 and references therein. Figs. 2, 3, 4, and 5). Upper Cretaceous and Paleocene-Eocene marine rocks crop out in the Arauco peninsula-Concepción area $\left(37^{\circ}-38^{\circ} \mathrm{S}\right.$. García, 1968; Stinnesbeck, 1986). Oligocene-Lower Miocene volcanic rocks are exposed in some parts of the coastal area and the Central Depression (Sernageomin, 1998; Muñoz et al., 2000). Upper OligoceneLower Miocene continental and marine strata crop out in the Coastal Cordillera and the Central Depression (Sernageomin, 1998; Encinas 


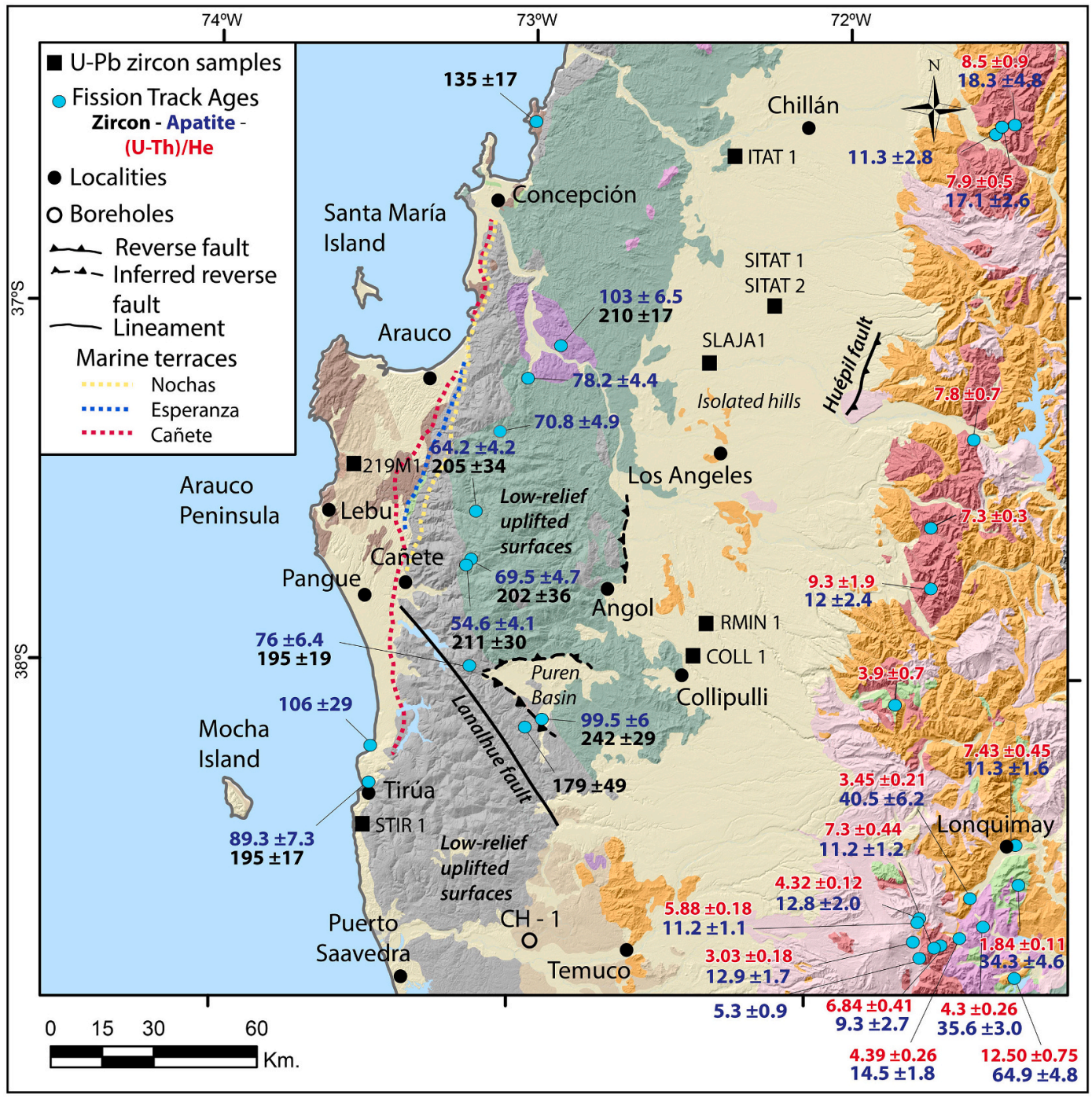

Fig. 3. Digital elevation model and geology of the Nahuelbuta segment. Main localities cited in the text, geomorphic (marine terraces, low-relief uplifted surfaces, and isolated hills), and main tectonic structures (reverse faults), as well as boreholes locations, are shown. U/Pb zircon samples from this study are shown as black squares, and previous thermochronological data are represented in turquoise dots (taken from Glodny et al., 2008; Spikings et al., 2008, Thomson et al., 2010). Geological units as in Fig. 2.

et al., 2012; Encinas et al., 2018). Middle-Upper Miocene, Pliocene, and Pleistocene marine deposits occur in some localities along the coast (Kaizuka et al., 1973; Biró-Bagoczky, 1979; Valenzuela, 1982). PlioPleistocene volcanoclastic and fluvial deposits are extensive in the Central Depression and some areas of the Coastal Cordillera (MuñozCristi, 1960; Hauser, 1986).

In the study area, the Coastal Cordillera is a subdued mountain range with variable altitudes, reaching maximum elevations of $\sim 1500 \mathrm{~m}$ (Nahuelbuta Mountains, $38^{\circ} \mathrm{S}$ ). The Central Depression (also known as Central Valley or Longitudinal Depression) is a low-relief area situated between the Coastal and the Andean Cordilleras that south of $\sim 42^{\circ}$ is submerged. The Coastal Cordillera presents segments with different altitudes (Figs. 1, 3, 4, and 5). There are two high-elevation areas with an N-S trending, asymmetrical dome-like morphology that Rehak et al. (2008) termed the Nahuelbuta $\left(\sim 37^{\circ}-38^{\circ} 30^{\prime} \mathrm{S}\right)$ and Bueno $\left(\sim 40^{\circ}-41^{\circ} \mathrm{S}\right)$ segments (Figs. 1, 3, and 5). These segments present maximum elevations of $\sim 1500 \mathrm{~m}$ (Nahuelbuta) and $1000 \mathrm{~m}$ a.s.l. (Bueno) and average elevations of $\sim 325$ and $250 \mathrm{~m}$ a.s.l, respectively. Between them, there is a lower-relief area with maximum elevations of $\sim 800 \mathrm{~m}$ a.s.l. and an average elevation of $\sim 140 \mathrm{~m}$ a.s.l., referred to as the Toltén segment by Rehak et al., 2008. Fig. 4). South of the Bueno segment, the Coastal
Cordillera reduces its altitude progressively and disappears at the Canal de Chacao, a marine strait between continental Chile and Chiloé Island where this range rises again (Fig. 5).

The segmentation is also reflected in the drainage-basin characteristics (Rehak et al., 2008). The Nahuelbuta and Bueno segments present deeply incised, E-W-trending valleys and record severe reorganizations of the drainage network, including wind gaps, knickpoints, flow reversals, and stream captures (Rehak et al., 2008). The Coastal Cordillera is primarily drained by locally sourced rivers in these areas. In fact, there are only five rivers born in the Andean Cordillera that traverse the entire forearc, the Bío-Bío, Imperial, Toltén, Calle- Calle, and Bueno rivers (Rehak et al., 2008. Fig. 1). Only the Bueno River transects the Bueno segment, whereas the Bio-Bio River borders the.

Nahuelbuta segment, and its outlet is located north of this domain. In contrast, the low-relief Toltén segment is drained by the Imperial, Toltén, and Calle-Calle rivers. These rivers lack ongoing incision and present broad alluvial plains with low-slope drainage that shows no signs of reorganization (Rehak et al., 2008). The highly dynamic fluvial systems characteristic of the Nahuelbuta and Bueno segments suggest ongoing uplift for these areas. Conversely, the lack of significant topographic contrasts, active incision, and recent river modifications, suggest that 


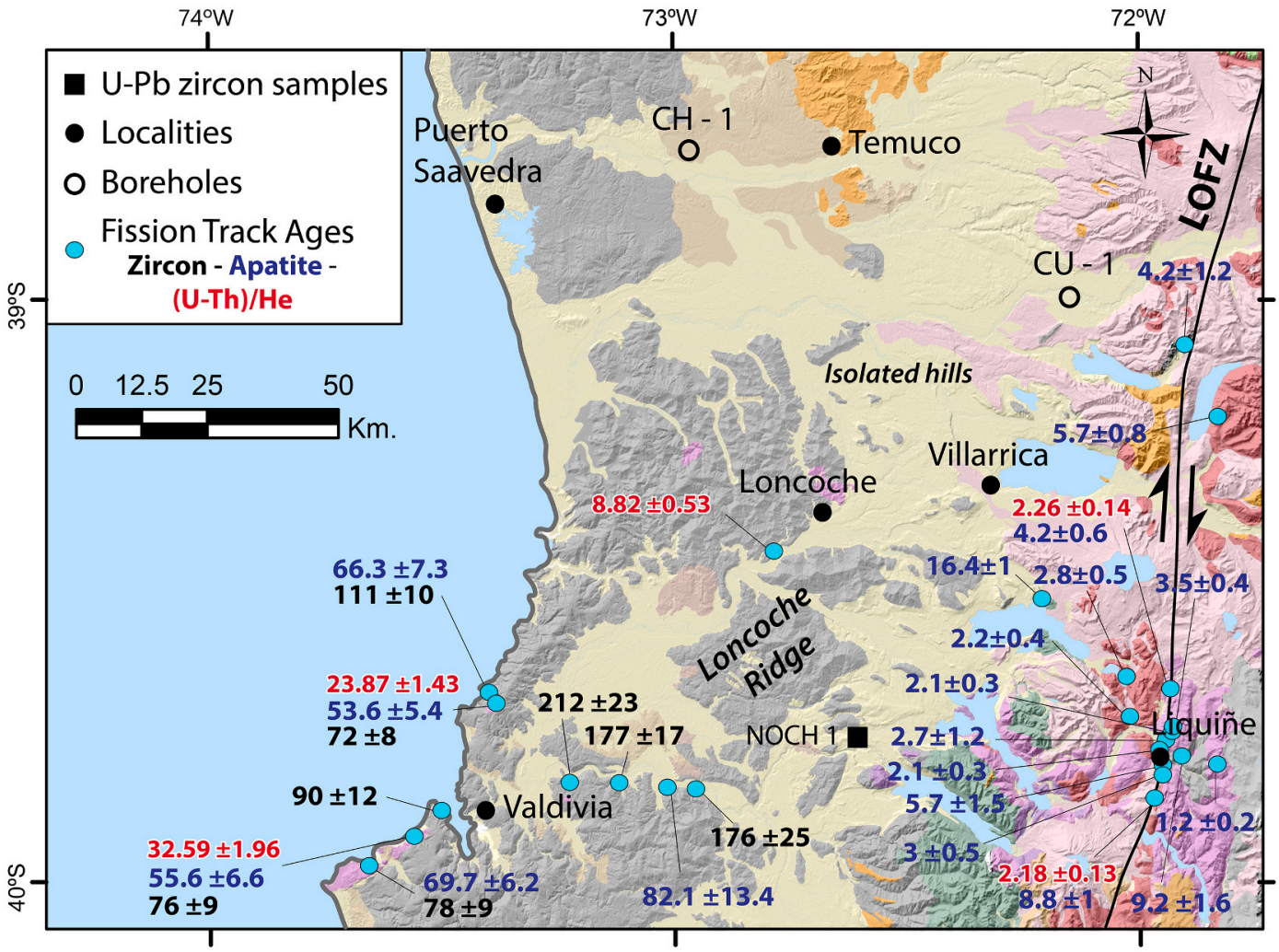

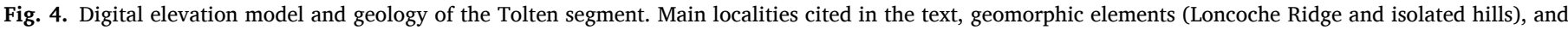

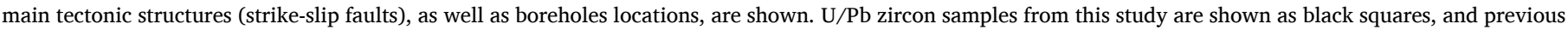
thermochronological data are represented in turquoise dots (taken from Glodny et al., 2008; Thomson et al., 2010). Geological units as in Fig. 2.

the Toltén segment is a tectonically stable area (Rehak et al., 2008).

The western flank of the Coastal Cordillera presents elevated planar surfaces with different heights and areal development depending on the area. Pioneer studies were carried out by Kaizuka et al. (1973), who described three uplifted surfaces in the Arauco-Nahuelbuta area $\left(37^{\circ}\right.$ $38^{\circ} \mathrm{S}$ ) that they interpreted as marine terraces. They were referred to as the Cañete, Esperanza, and Nochas surfaces that reach maximum heights of 232, 360, and 471 m a.s.l. (Figs. 3, and 14a). Kaizuka et al. (1973) and Melnick et al. (2009) ascribed these terraces to different interglacial sealevel highstands and correlated the Cañete, Esperanza, and Nochas surfaces with marine oxygen isotope stages (MIS) 5e (130-116 ka), 7 $(220-200 \mathrm{ka})$ and $9(340-320 \mathrm{ka})$ respectively. These terraces have variable heights and show a similar landward tilting and an upwarping with an NW-SE trending axis (Kaizuka et al., 1973; Rehak et al., 2008). Although detailed studies on marine terraces have been carried out only in the Arauco-Nahuelbuta area, these are conspicuous along the study area. For example, in the Valdivia region, where Illies (1970) described three elevated surfaces at 270,430 , and $520 \mathrm{~m}$ a.s.l. that likely correlate with those defined by Kaizuka et al. (1973).

The geological history of the forearc of south-central Chile started in the late Paleozoic with the development of a broad accretionary wedge during Devonian to Triassic times (Duhart et al., 2001). Magmatic arc granitoids crystallized in the Late Carboniferous to Early Permian (Glodny et al., 2008). Zircon and apatite fission-track data in the present Coastal Cordillera of south-central Chile $\left(36^{\circ}-42^{\circ}\right.$ S. Figs. 3, 4, and 5) indicate significant exhumation of these rocks during the Triassic, ending around 200 Ma (Glodny et al., 2008). Exhumation has been remarkably slow in this area since that period, with long-term average rates of 0.03-0.04 mm/a (Glodny et al., 2008). This notion is supported by two (U-Th)/He ages obtained by Thomson et al. (2010) near Valdivia that also indicate slow exhumation rates (Fig. 4). In addition, the occurrence of Middle to Late Triassic non-metamorphic, marine and continental successions discordantly overlying Late Carboniferous to Early Permian granitoids implies near-surface positions of parts of this basement already in the Triassic (Glodny et al., 2008). Subsequently, no sedimentary or magmatic activity occurred in the forearc until the Late Cretaceous when restricted plutonic activity took place in the coastal area near Valdivia ( $\sim 40^{\circ}$ S. Mella et al., 2012) and the Loncoche Ridge (Duhart et al., 2003). Afterward, the sedimentary record indicates subsequent intervals of uplift and subsidence that gave way to transgressive and regressive events. Marine successions accumulated during the Maastrichtian (Stinnesbeck, 1986), the Paleocene-Eocene (Lebu Group; García, 1968), the late Oligocene-early Miocene (Encinas et al., 2018 and references therein), the middle-late Miocene (Valenzuela, 1982; Álvarez et al., 2006; Nielsen and Glodny, 2009; Encinas et al., 2012), the Pliocene (Biró-Bagoczky, 1979), and the Plio-Pleistocene (Kaizuka et al., 1973). However, these events did not lead to exhumation detectable by the apatite fission-track method (Glodny et al., 2008). The only exception is a final Pliocene to recent cooling episode in the Nahuelbuta segment (Glodny et al., 2008). Glodny et al. (2008) also identified Apatite Fission Track Late Cretaceous, Eocene, and late Oligocene ages that they interpreted as thermal anomalies caused by magmatism.

\subsubsection{Andean Cordillera}

In the study area, the Andean Cordillera (also known as Main or Principal Cordillera) has active volcanoes and the highest peaks that reach maximum altitudes of $\sim 3500 \mathrm{~m}$. At $\sim 38^{\circ} \mathrm{S}$, the Andean Cordillera exhibits a significant geomorphologic change as the broad and high $(>4000 \mathrm{~m})$ Central Andes to the north give way to the narrow and relatively low $(\sim 2000 \mathrm{~m})$ North Patagonian Andes to the south (Hervé, 1994). The oldest rocks of the Andean Cordillera are middle-late Paleozoic metamorphic rocks (Duhart et al., 2001). Late Jurassic to Miocene plutonic rocks are dominant south of $\sim 38^{\circ} \mathrm{S}$ due to high exhumation rates in this area during the late Cenozoic (Mpodozis and 


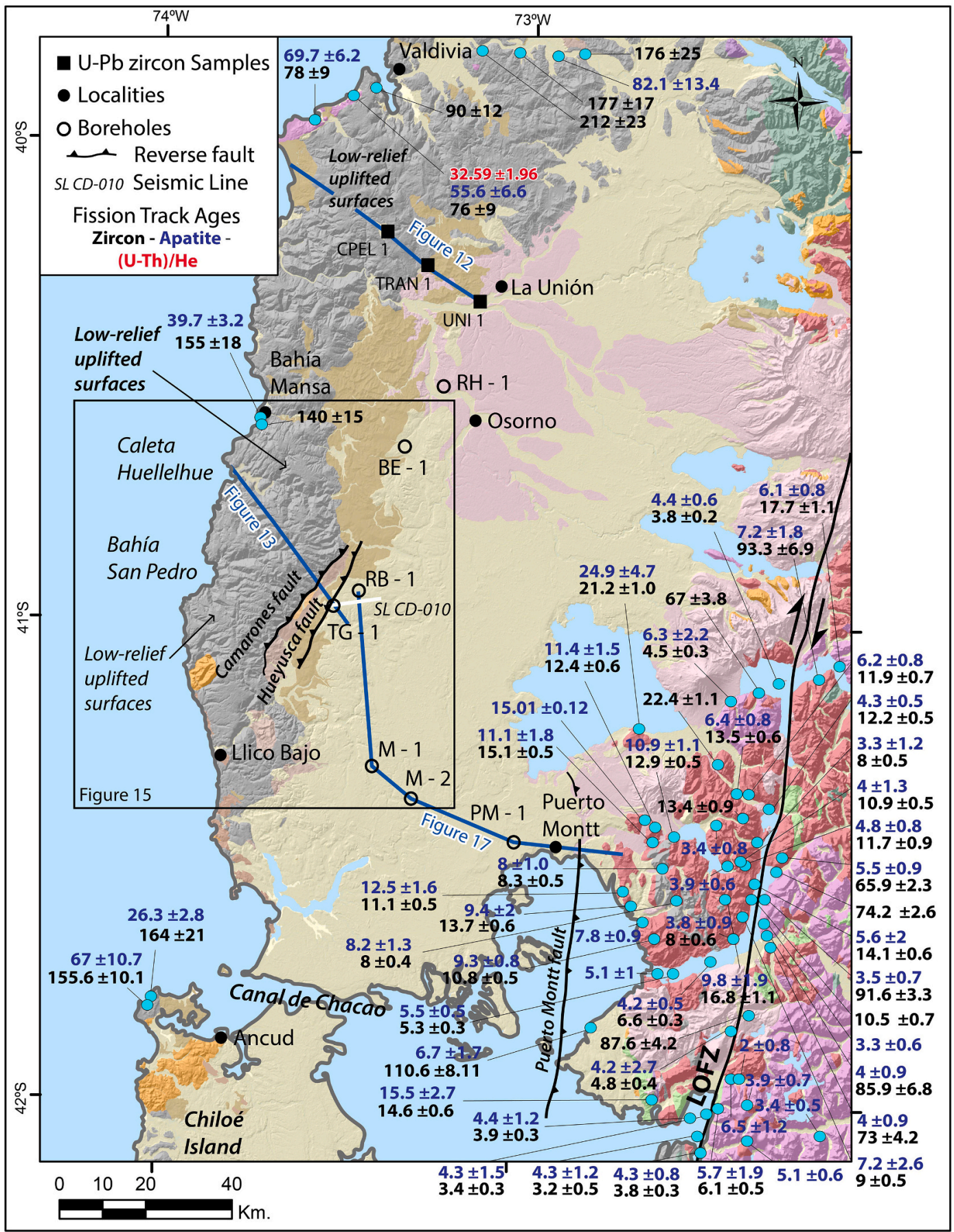

Fig. 5. Digital elevation model and geology of the Bueno segment. Main localities cited in the text, geomorphic (low relief uplifted surfaces), and main tectonic structures (reverse and strike-slip faults), as well as boreholes locations, are shown. Blue lines represent the traces of structural profiles of Figs. 12, 13, and 17. Inset shows the location of Fig. 15. U/Pb zircon samples from this study are shown as black squares, and previous thermochronological data are represented in turquoise dots (taken from Glodny et al., 2008; Thomson et al., 2010; Adriasola, 2003; Adriasola et al., 2005). Geological units as in Fig. 2.

Ramos, 1989). Paleogene and Neogene volcanic, volcaniclastic, and sedimentary rocks are abundant north of $38^{\circ} \mathrm{S}$ (Sernagemin, 2003).

Extensional tectonic conditions characterized the Chilean margin during the Late Triassic to the late Early Cretaceous (Mpodozis and Ramos, 1989). A series of interconnected backarc basins that were filled with thick successions of marine and continental sedimentary strata developed in this period (Mpodozis and Ramos, 1989). Afterward, The Andean Cordillera has been contractionally deformed in two main deformational phases, one spanning from the late Early Cretaceous to the early Paleocene and another in Neogene times (Orts et al., 2012;
Rojas Vera et al., 2015; Giambiagi et al., 2016; Encinas et al., 2018; Horton, 2018). Extensional or neutral tectonic conditions prevailed during the Paleocene-Eocene (Echaurren et al., 2016; Horton, 2018), and an important phase of extensión took place during the Oligoceneearly Miocene (Muñoz et al., 2000; Jordan et al., 2001). A significant tectonic discontinuity in the Andean Cordillera is the N-S, dextral strikeslip, Liquiñe-Ofqui fault zone (LOFZ), which extends from the Chile triple junction at $46^{\circ} 30^{\prime} \mathrm{S}$ to the Copahue volcano at $38^{\circ} \mathrm{S}$ (Hervé, 1994). Structural analyses, $\mathrm{Ar}-\mathrm{Ar}$ geochronology, and fission-track thermochronology indicate right-lateral transpression along the LOFZ during 
the Late Miocene to Pliocene (e.g., Cembrano et al., 2002; Thomson, 2002; Adriasola et al., 2005).

In central Chile $\left(\sim 33^{\circ}-34^{\circ} \mathrm{S}\right)$, a reverse fault in the limit between the Central Depression and the western part of the Andean Cordillera (the San Ramón Fault) has been interpreted as a west vergent, crustal-scale thrust named the West Andean Thrust (WAT) by Armijo et al. (2010). Farías et al. (2008a) and Armijo et al. (2010) estimated the throw of the San Ramón fault in 600-1100 m and $3500 \mathrm{~m}$, respectively. In southcentral Chile, the nature of the contact between the Central Depression and the Andean Cordillera is not evident due to the abundant vegetation that characterizes this area. There is a major, approximately linear, N-S oriented, topographic change in the limit between these morphostructural units that suggest a tectonic contact (Figs. 1, 2, 3, 4, and 5). In support of this notion, the Plio-Pleistocene deposits that fill most of the Central Depression show progressively higher elevations towards the western flank of the Andean Cordillera, where they reach elevations up to $\sim 700 \mathrm{~m}$ m.a.s.l. (Ferraris, 1981). Melnick et al. (2006) identified a reverse fault (the Huépil Fault) affecting beds of the Rodados Multicolores Formation in the limit between the Andean Cordillera and the Central Depression at $37^{\circ} \mathrm{S}$ (Fig. 3). Sepúlveda et al. (2019) identified another reverse fault (the Mesamávida Fault) at $36^{\circ} \mathrm{S}$. Based on seismic information, González (1983) recognized a major, almost vertical, west-vergent reverse fault (the Puerto Montt Fault, $41^{\circ} 30^{\prime} \mathrm{S}$ ) in the limit between the Andean Cordillera and the Central Depression. Encinas et al. (2013) noted that the ENAP Puerto Montt 1 well (PM-1), in the eastern part of the Central Depression, transected Upper OligoceneLower Miocene marine strata covered by $2250 \mathrm{~m}$ of Plio-Pleistocene deposits (Figs. 5, and 17), whereas strongly deformed correlative strata of the Ayacara Formation crop out in the western flank of the Andean Cordillera only $\sim 20 \mathrm{~km}$ to the east (Encinas et al., 2013). Upper Miocene and Pliocene plutonic rocks crop out in the same area (Duhart, 2008). Thus, a minimum vertical throw of $\sim 2000 \mathrm{~m}$ for the Puerto Montt fault is deducted from the topographic difference between the top of the Miocene marine strata transected by the well and the altitude of the correlative Ayacara Formation (Encinas et al., 2013). A maximum Pliocene age for this fault is inferred from the occurrence of plutonic rocks of this age in the western Andean Cordillera.

The occurrence of a major thrust between the forearc and the Andean Cordillera has derived in a hot debate in the interpretation of the kinematics, style of deformation, and tectonic drivers of the Andes of central Chile and Argentina (see Armijo et al., 2010; Astini and Dávila, 2010). Classical studies propose that shortening in the Andean Cordillera is associated with an eastward propagation of deformation into the foreland (e.g., Mpodozis and Ramos, 1989; Charrier et al., 2007; Farías et al., 2010; Giambiagi et al., 2014). In this model, the WAT simply corresponds to a second-order backthrust (e.g., Astini and Dávila, 2010; Farías et al., 2010). However, Armijo et al. (2010) challenged this conception proposing that Andean deformation progressively shifted trenchward (westward) instead of cratonward (eastward) since $\sim 25-22$ Ma ago. According to these authors, the shortening process has continued to the present time by westward propagation of the WAT up to the current West Andean Front. Armijo et al. (2010) proposed that the Central Depression is not a forearc basin, as currently considered, but a foreland basin located west of the Andes and generated by orogenic loading. In concordance with this notion, they proposed that the uplift of the Coastal Cordillera was caused by elastic fore-bulging ahead of the foreland flexure (Armijo et al., 2010).

Astini and Dávila (2010) questioned this model because they argued that the tectonic load caused by the westward migration of the Andes of central Chile and Argentina since the early Miocene should have triggered the deposition of $\sim 4-6 \mathrm{~km}$ of synorogenic Neogene deposits in the forearc (the western foreland in Armijo et al., 2010 model). They noted that thick accumulations of Neogene synorogenic strata occur instead in the eastern flank of the Andes, which have progressively moved eastward since $\sim 20 \mathrm{Ma}$. They further indicated that there is no stratigraphic evidence to sustain that the uplift of the Coastal Cordillera was caused by elastic fore-bulging, nor this hypothesis is compatible with flexural calculations.

Several authors carried out thermochronological studies in the western slope of the Andean Cordillera of central and south-central Chile (e.g., Thomson, 2002; (Adriasola et al., 2005; Glodny et al., 2008; Spikings et al., 2008; Maksaev et al., 2009; Thomson et al., 2010). Interpretation of these data in terms of deformation and exhumation is not straightforward due to the magmatism-related fluctuations in the paleogeothermal field that characterize this part of the Andes (Glodny et al., 2008).

Maksaev et al. (2009) carried out zircon and apatite fission-track thermochronology for Miocene plutons of the western slope of the Andean Cordillera in central Chile $\left(33-35^{\circ} \mathrm{S}\right)$. Their data indicate a distinctive episode of enhanced cooling between about 6 and 3 Ma that they attributed to accelerated exhumation rates caused by compressive tectonism. They related this episode with the sedimentation of PlioPleistocene coarse-grained conglomerates in the western flank of the Andes and the forearc by mass wasting processes. Maksaev et al. (2009) proposed that rapid erosion could have triggered magma desgassing and the development of huge $\mathrm{Cu}-$ Mo mineral deposits. Rapid exhumation in this area coincides with the southward migration of the subducting Juan Fernández Ridge and the development of progressive subduction flattening northward of $33^{\circ} \mathrm{S}$, according to Maksaev et al. (2009).

Spikings et al. (2008) analyzed ${ }^{40} \mathrm{Ar} /{ }^{39} \mathrm{Ar}$, apatite fission-track, and zircon and apatite ( $\mathrm{U}-\mathrm{Th}$ )/He data from granitoids in the western slope of the Andean Cordillera between $35^{\circ}$ and $38^{\circ} \mathrm{S}$ (Fig. 3). They identified two episodes of rapid cooling. The first one took place between 18 and $15 \mathrm{Ma}$ and was attributed by these authors to both thermal relaxation following magmatic intrusion and possibly regional-scale tectonic exhumation (Spikings et al., 2008). The second event took place during the late Miocene, commencing at 7.5-7.0 Ma, and was caused by tectonic exhumation that the authors suggested may be a consequence of the subduction of the Juan Fernandez Ridge above the flat-slab segment.

Glodny et al. (2008) carried out apatite fission-track thermochronology between $37^{\circ}$ and $40^{\circ} \mathrm{S}$ (Figs. 3, 4, and 5). Most of these ages range between the late Miocene and the Pleistocene (see Fig. 2 in Glodny et al., 2008). There is also one Miocene age (16.4 Ma) near Villarrica and two Eocene ages (40.5 and 34.3 Ma) near Lonquimay. Based on these results, they proposed that there are more rapid exhumation rates near Liquiñe $\left(\sim 40^{\circ} \mathrm{S}\right)$ than in the Lonquimay area $\left(\sim 38^{\circ} \mathrm{S}\right)$ that they attributed to more intense glacial erosion in the southern part of their study area during the Late Miocene to Pleistocene. They also noted that there is no distinct evidence for differential exhumation along the Liquiñe Ofqui Fault Zone near Liquiñe as proposed by Adriasola et al. (2006) and Thomson (2002) for the area between $41^{\circ}$ and $46^{\circ} \mathrm{S}$.

Adriasola et al. (2006) carried out zircon and apatite fission-track thermochronology between $\sim 41^{\circ}$ and $42^{\circ} \mathrm{S}$ (Fig. 5). They interpreted rapid cooling at 5-3 Ma along both sides of the Liquiñe Ofqui Fault Zone, whereas older Miocene ages with monotonous cooling histories were obtained further away from the fault. According to Adriasola et al. (2006), right-lateral transpression caused Pliocene enhanced cooling along the LOFZ.

Thomson (2002) analyzed zircon and apatite fission-track data between $42^{\circ}$ and $46^{\circ} \mathrm{S}$ (Fig. 5). They interpreted that the area was subjected to enhance cooling and denudation initiated ca. 16-10 Ma with very fast cooling between 7 and 2 Ma. They identified several fault blocks with different cooling histories showing denudation increase from east to west. They related exhumation to transpression associated with the activity of the LOFZ balanced by high rates of glacial erosion.

Thomson et al. (2010) obtained apatite (U-Th)/He ages and apatite fission-track (AFT) ages from several samples collected $38^{\circ}$ and $56^{\circ} \mathrm{S}$ (Figs. 3, 4, and 5). Based on these data, they proposed high exhumation rates for the $38^{\circ}-49^{\circ} \mathrm{S}$ segment between 7 and $5 \mathrm{Ma}$. They attributed this event to the combination of major Patagonian glaciation with the retreat of tectonic deformation from the easternmost thrust front towards the western slope of the Andes. In contrast, older cooling ages were recorded 
at higher latitudes $\left(49^{\circ}\right.$ to $\left.56^{\circ} \mathrm{S}\right)$, which Thomson et al. (2010) attributed to the protective effect of a thicker ice cover that resulted on more reduced erosion than further north.

\subsection{Forearc Cenozoic stratigraphy}

In the following section, we describe the most important units of sedimentary and volcanic rocks accumulated in the forearc of southcentral Chile during the Oligocene to present (Figs. 2, and 6). We focus on the rocks deposited during this period because they are crucial to constraint the evolution of the Coastal Cordillera and Central Depression.

\subsubsection{Oligocene-Lower Miocene volcanic rocks}

Oligocene-Lower Miocene volcanic rocks (Fig. 6), including andesites, basalts, and minor dacites, occur locally in some areas of the forearc of south-central Chile (Fig. 2). These rocks were referred to as the Coastal Volcanic Belt by Vergara and Munizaga (1974). Coeval volcanic rocks are exposed in the Andean Cordillera and the foreland (Muñoz et al., 2000; Jordan et al., 2001). The geochemistry of the OligoceneLower Miocene volcanic rocks suggests that they were emplaced on a thinned crust under an extensional tectonic regime (e.g., Muñoz et al., 2000; Jordan et al., 2001, and references therein). The volcanic rocks of the Coastal Volcanic Belt overlie the metamorphic Paleozoic basement or Eocene? continental sedimentary rocks (Rubio, 1990; Muñoz et al., 2000). The thickness of the volcanic rocks is difficult to determine, but it reaches $360 \mathrm{~m}$ in a well drilled near Temuco (39 ${ }^{\circ}$. Rubio, 1990. Fig. 2). Although some of the volcanic rocks that crop out in the forearc have been assigned to the Eocene, radiometric dating indicates that most of them were emplaced during the Oligocene-Early Miocene (Muñoz et al., 2000; Mella and Quiroz, 2010). In the Los Ángeles-.

Temuco area $\left(\sim 37^{\circ}-39^{\circ}\right.$ S. Fig. 2$)$, these rocks crop out in the Central Depression and the eastern flank of the Coastal Cordillera having been assigned to the Huelehueico (north area) and Pilmahue (south area) formations by Elgueta and Rubio (1991) and García (1968) respectively. Further south, volcanic rocks of the Caleta Parga and Ensenada Capitanes formations crop out in the coastal area at $\sim 41^{\circ} \mathrm{S}$ (Muñoz et al., 2000) (Fig. 2).

\subsubsection{Upper Oligocene-Lower Miocene continental sedimentary rocks}

Fluvial, alluvial, and estuarine strata composed of sandstone, siltstone, conglomerate, and coal occur locally in the Central Depression and the Coastal Cordillera of south-central Chile (Sernageomin, 1998. Figs. 2 and 6). They have been defined by several local names such as the Cheuquemó Formation, the Temuco Formation, the San Pedro Formation, the Estratos de Pupunahue, the Osorno Formation, the Estratos de Pupunahue-Catamutún, and the Parga Formation (Finger and Encinas, 2009 and references therein). These units overlie the metamorphic basement and underlie Upper Oligocene-Lower Miocene marine strata. The thickness of these successions varies between a few meters to 1200 $\mathrm{m}$, as determined in wells drilled in the Central Depression (Elgueta et al., 2000). Different ages, ranging from Eocene to Miocene, have been assigned to these units (Finger and Encinas, 2009, and references therein). Zircons from ash-layers interbedded with coal-beds in two localities near Valdivia ( $40^{\circ} \mathrm{S}$. Fig. 2) yielded $\mathrm{U}-\mathrm{Pb}$ ages of 23.5 and 21.8 Ma respectively (Sernageomin, 1998; Elgueta et al., 2000; Elgueta and Mpodozis, 2012), which indicates a Late Oligocene-Early Miocene age. However, other authors propose an Eocene age for these strata based on pollen and foraminifers (see Finger and Encinas, 2009, and references therein). This suggests the possible existence of two coal-bearing successions of Eocene and latest Oligocene-earliest Miocene ages.

\subsubsection{Upper Oligocene-Lower Miocene marine sedimentary rocks}

Upper Oligocene-Lower Miocene marine strata occur at different localities in the forearc and the Andean Cordillera of central and southern Chile between $\sim 33^{\circ}$ and $45^{\circ} \mathrm{S}$ (Encinas et al., 2018 and

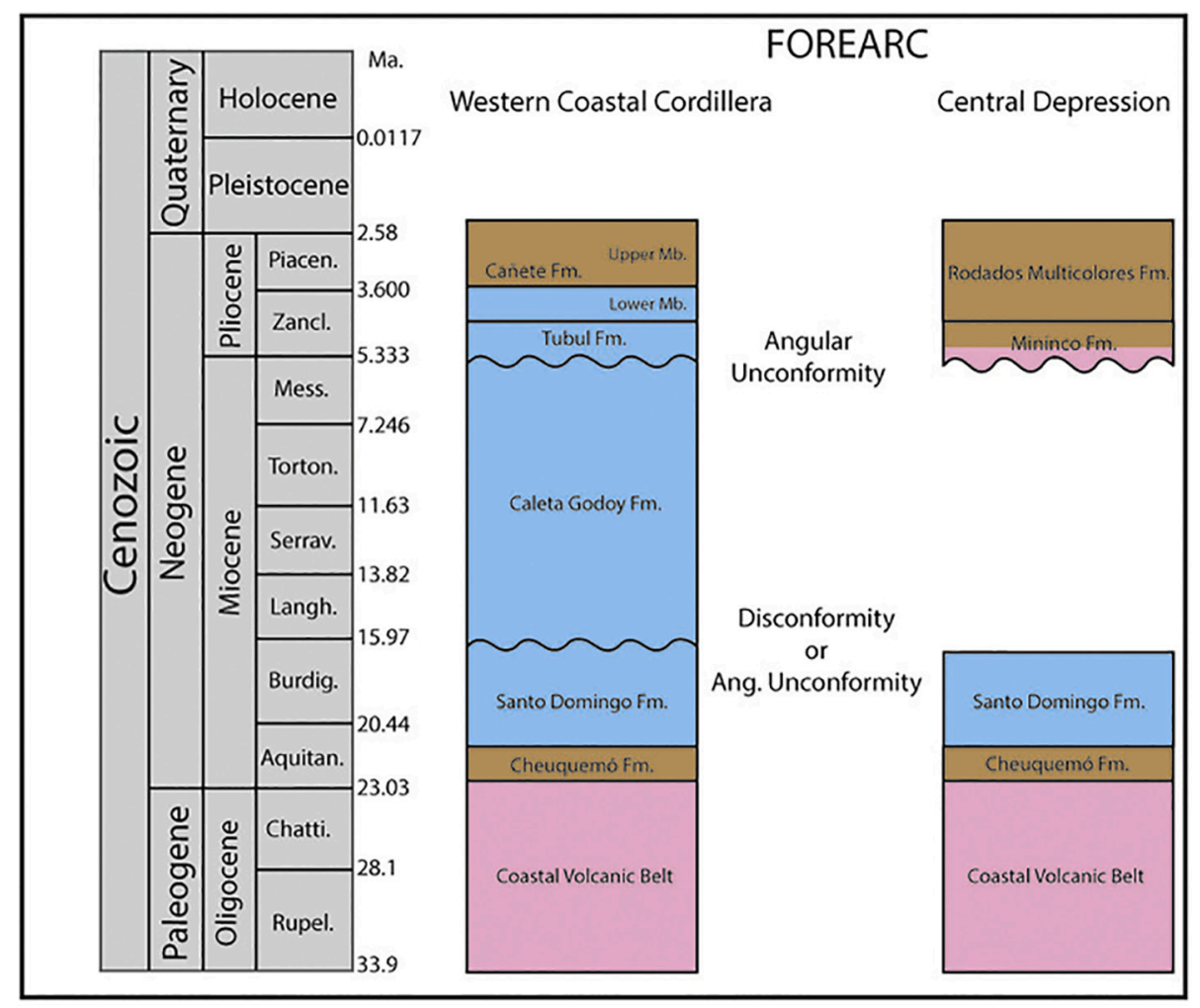

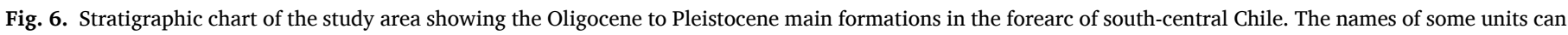

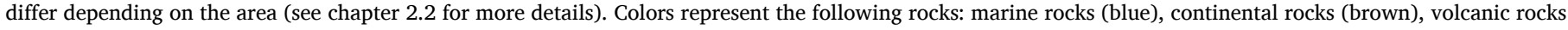
(pink). (For interpretation of the references to colour in this figure legend, the reader is referred to the web version of this article.) 
references therein). In the study area, they crop out on the coast of the Arauco Peninsula (Ranquil Formation, $\sim 37-38^{\circ} \mathrm{S}$ ), and in the Coastal Cordillera and Central Depression between $\sim 38-42^{\circ} \mathrm{S}$ (Cholchol and Santo Domingo formations. Encinas et al., 2012. Figs. 2, and 6). These units overly the metamorphic basement, Oligocene-Lower Miocene volcanic rocks, or Upper Oligocene-Lower Miocene continental strata (Rubio, 1990; Elgueta et al., 2000; Encinas et al., 2012, 2018). The marine formations consist of sandstone, siltstone, and minor conglomerate containing abundant and diverse fauna (Encinas et al., 2012, and references therein). Wells drilled in the Central Depression indicate a thickness of up to $1500 \mathrm{~m}$ for these strata (Elgueta et al., 2000). Sedimentologic, ichnologic, and paleontologic studies indicate deposition in a deep-marine environment (Encinas et al., 2012; Finger, 2013). Analysis of seismic lines (Elgueta et al., 2000; Jordan et al., 2001; Melnick and Echtler, 2006) indicate the presence of normal faults and synextensional growth strata in these units. The age of these deposits has been a matter of debate for decades (Encinas et al., 2018). An early Miocene age was derived principally from studies on mollusks, and shark teeth, whereas a middle to late Miocene or early Pliocene age for these units had been interpreted from the study of foraminifers,
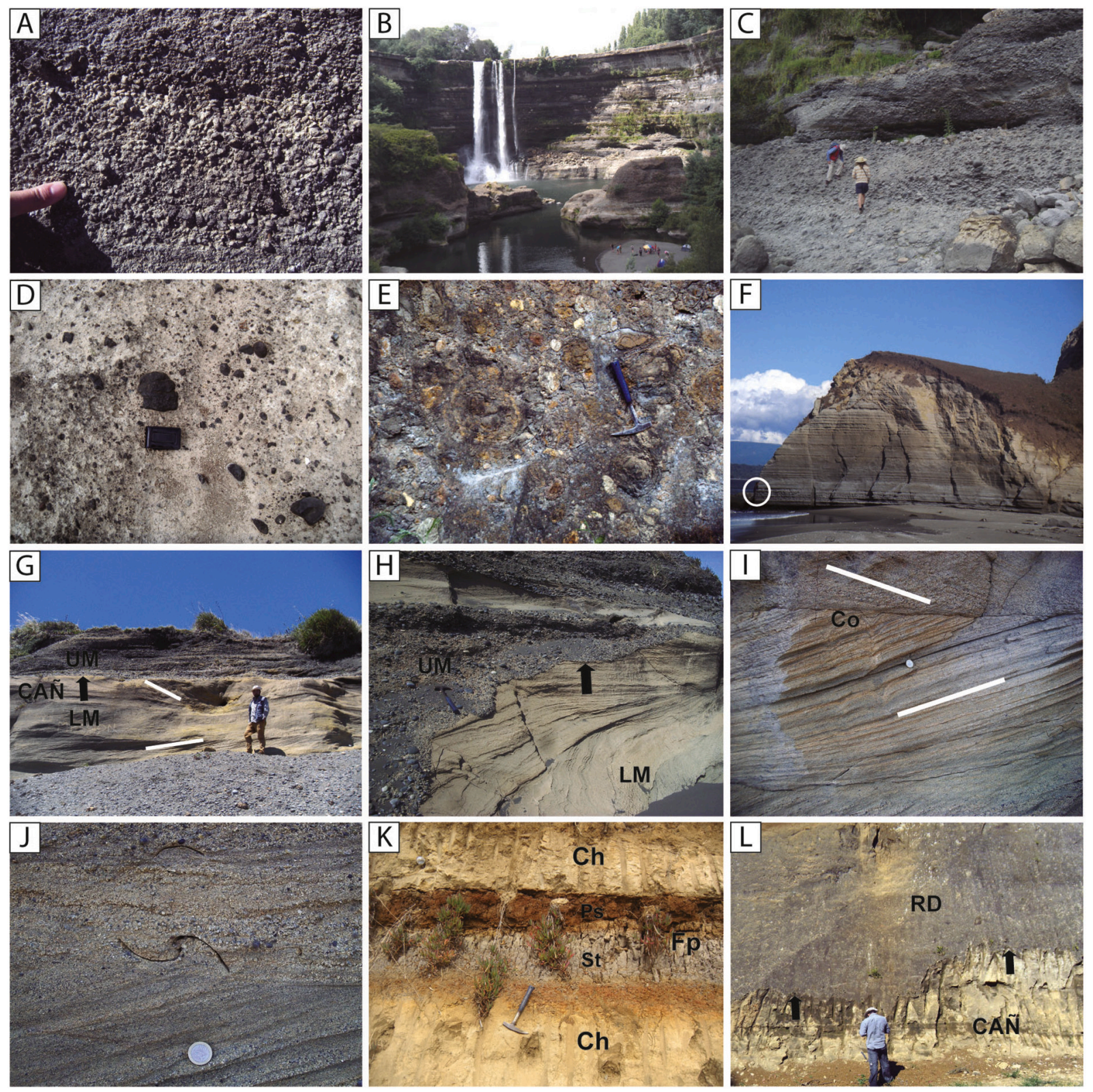

Fig. 7. Characteristic features from the Plio-Pleistocene deposits of the forearc of south-central Chile. (A) Pumice conglomerate of the Mininco Formation (sample ITAT 1). (B) Fluvial and lahar deposits of the Rodados Multicolores Formation at the Itata River banks (samples SITAT 1 and 2 were obtained here). (C) Detail of clastsupported, fluvial conglomerates from the basal part of the succession. (D) Detail of matrix-supported, lahar conglomerates from the upper part of the succession. Camera case is $10 \mathrm{~cm}$ long. (E) Intensely weathered clast-supported conglomerated of the Rodados Multicolores Formation in a roadcut $\sim 25 \mathrm{~km}$ east of Temuco. Note rinds around a harder, less altered core. (F) Silty sandstones of the Tubul Formation in the northern part of the Arauco Peninsula. (G) Contact (indicated by arrow) between sandstones of the lower marine (estuarine) member (LM) and conglomerates of the upper fluvial member (UM) of the Cañete Formation (CAÑ) in the southern part of the Arauco Peninsula. Note bimodal paleocurrent directions of cross-bedded sandstones in the lower marine member. (H) Detail of the contact. (I) Detail of cross-bedded sandstones with bimodal paleocurrent directions in the lower member. Note also Conichnus (Co) trace fossil. (J) Detail of bivalve molds in the lower member. (K) Fluvial deposits of the upper member of the Cañete Formation in the central part of the Arauco Peninsula. Note sandy Channel deposits (Ch) and silty (St) floodplain deposits (Fp) with paleosoil (Ps). (L) Disconformity between fluvial deposits of the Cañete Formation (CAÑ) bearing volcanic clasts and recent fluvial deposits (RD) containing metamorphic and plutonic basement clasts. Roadcut near Tirúa. See localities in Figs. 3, 4, and 5. 
ostracodes, and pollen (Encinas et al., 2018 and references therein). However, ${ }^{87} \mathrm{Sr} /{ }^{86} \mathrm{Sr}$ ages (Nielsen and Glodny, 2009), and reexamination of planktic foraminifers (Finger, 2013) confirm a Late Oligocene-Early Miocene age for these units.

\subsubsection{Middle-Upper Miocene marine sedimentary rocks}

Marine deposits of this age (Fig. 6) crop out only in a few localities of the study area (Fig. 2). In the Arauco Peninsula $\left(37^{\circ}-38^{\circ} \mathrm{S}\right)$, an unnamed succession of fossiliferous sandstones overlying the Ranquil Formation was assigned to the late Early-early Middle Miocene $(16.1+0.64$ / $-0.56 \mathrm{Ma}$ ) by Sr isotope stratigraphy (Nielsen and Glodny, 2009). A succession of similar characteristics, defined as the Caleta Godoy Formation, crops out along the coast between $\sim 41^{\circ}-42^{\circ} \mathrm{S}$ and was tentatively assigned to the Miocene by Valenzuela (1982). This unit shows a disconformity or an angular unconformity with the Santo Domingo Formation and has a maximum thickness of $500 \mathrm{~m}$ (Antinao et al., 2000; Encinas et al., 2012). In the offshore area west of the Arauco Peninsula $\left(37^{\circ}-38^{\circ} \mathrm{S}\right)$, Álvarez et al. (2006) identified middle-upper Miocene marine deposits with growth strata indicative of compressive deformation.

\subsubsection{Pliocene-Pleistocene marine and continental deposits}

Marine and continental deposits accumulated during the PliocenePleistocene interval crop out in the Central Depression and the coastal area (Fig. 2). These deposits have horizontal strata and present an angular unconformity with Oligocene-Miocene strata and a nonconformity with Paleozoic-Triassic metamorphic and plutonic rocks.

2.2.5.1. Central depression. The oldest Plio-Pleistocene unit in the
RUTA ITATA

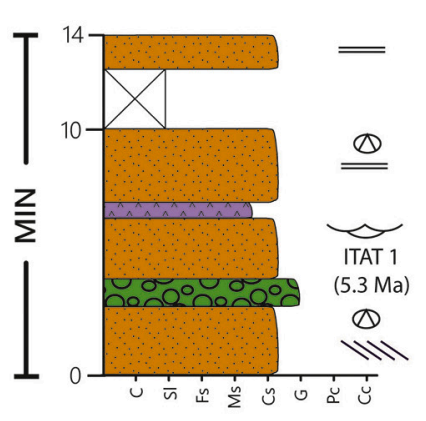

P. RAULINTAL

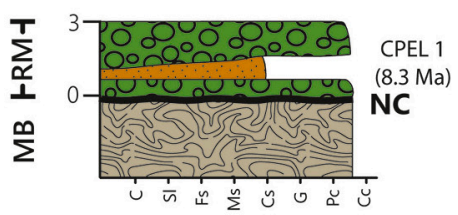

LA UNIÓN

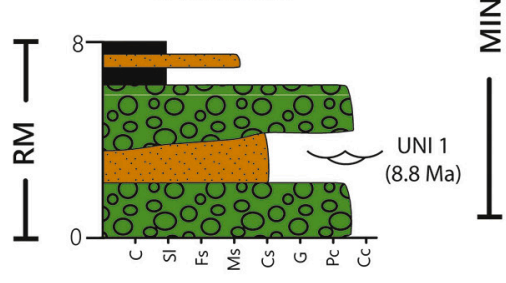

RÍO MININCO

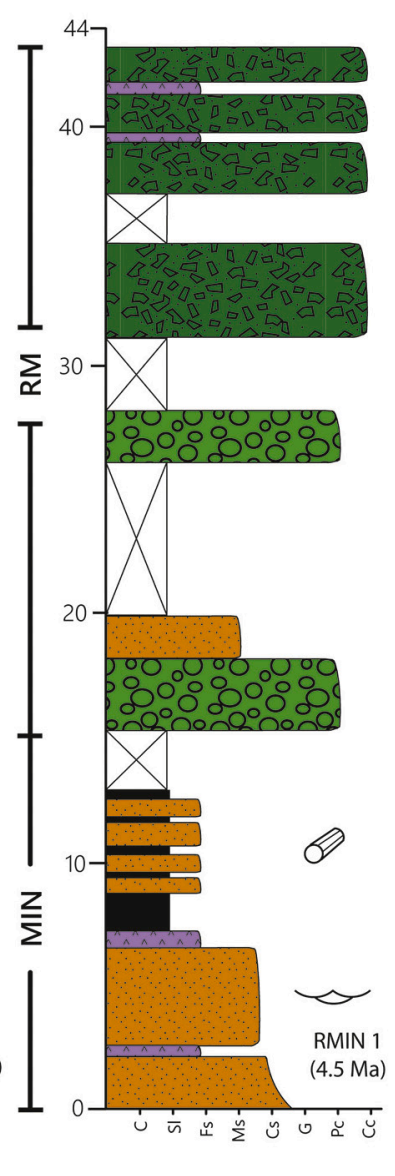

LAS TRANCAS

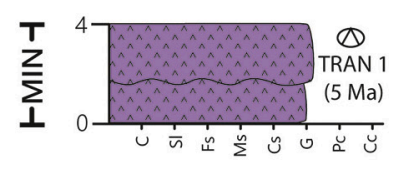

SALTOS DEL ITATA

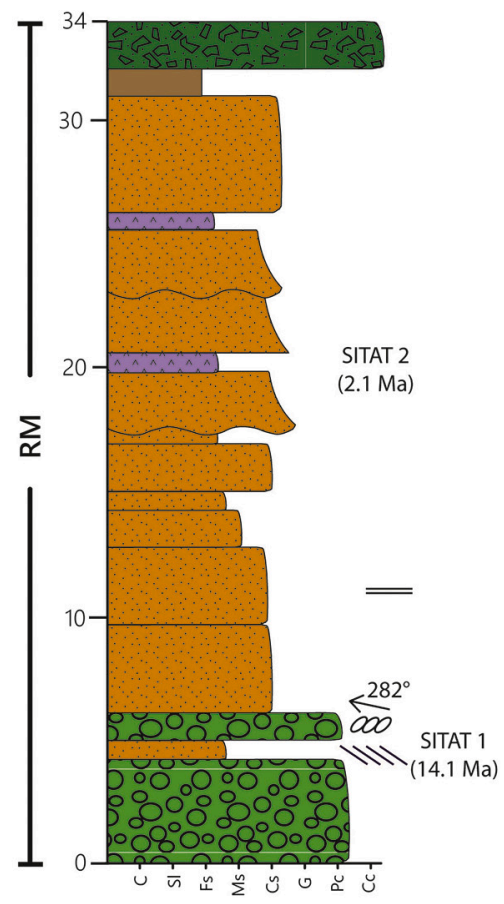

LEGEND

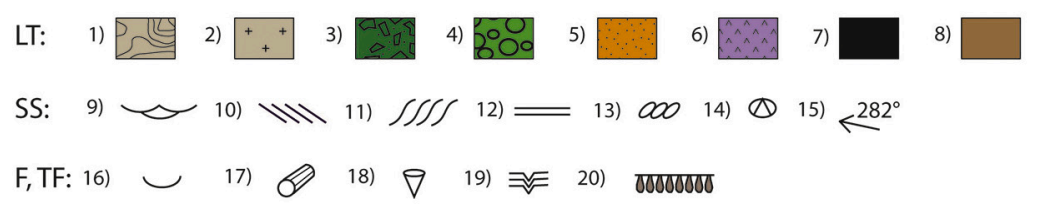

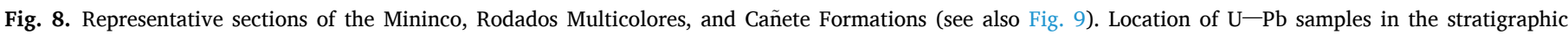

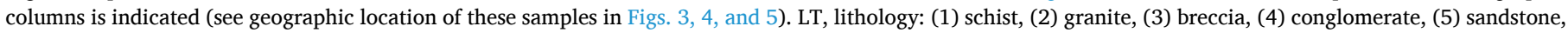

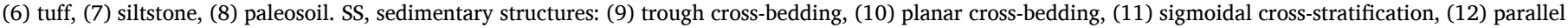

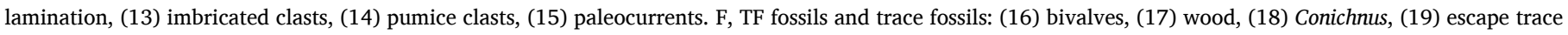

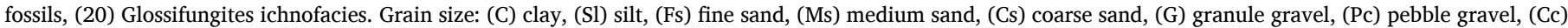

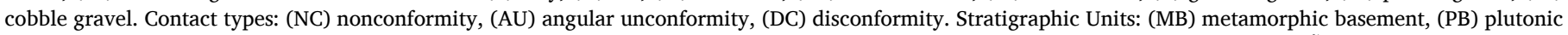

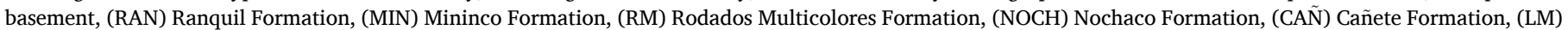
Lower Member, (UM) Upper Member. 
Central Depression is the Mininco Formation (Muñoz-Cristi, 1960. Fig. 6). These deposits overly Carboniferous-Permian plutonic rocks and Oligocene-Lower Miocene volcanic rocks (Ferraris, 1981). Outcrops of the Mininco Formation are scarce as they are typically covered by the Rodados Multicolores Formation. The thickness of this unit is unknown. The Mininco Formation consists of sandstones, conglomerates, tuffaceous siltstones, and tuffs (Fig. 7a, and 8). The Mininco Formation was tentatively assigned to the Plio-Quaternary by Muñoz-Cristi (1960).

The Rodados Multicolores Formation (Fig. 6) was defined by Hauser (1986) as a predominantly conglomeratic succession that crops out extensively in the Central Depression of south-central Chile between $\sim 36^{\circ}$ and $42^{\circ} \mathrm{S}$, although similar deposits extend continuously to the north until $\sim 33^{\circ} \mathrm{S}$. minor outcrops are exposed at higher elevations in the eastern flank of the Coastal Cordillera and in the western flank of the Andes (Hauser, 1986). In some areas $\left(39^{\circ}-40^{\circ} \mathrm{S}\right)$, these deposits extend continuously from the Andean Cordillera to the coastal area (Fig. 2). The Rodados Multicolores Formation conformably overlies the Mininco Formation and presents an angular unconformity with Oligo-Miocene volcanic and sedimentary rocks and a non-conformity with metamorphic and plutonic basement rocks (Hauser, 1986). Information from wells drilled in the Central Depression indicates that the thickness of this unit is highly variable, from a few meters to more than $1000 \mathrm{~m}$ (Hauser, 1986; Vergara et al., 1997; Elgueta et al., 2000). The Rodados Multicolores Formation consists of conglomerates, sandstones, and minor siltstones and tuffs (Fig. 7b, c, d, e, 8, and 9). This unit was tentatively assigned to the Plio-Pleistocene by (Hauser, 1986).

A conglomeratic succession that we define here as the Nochaco Formation (Figs. 6, and 9) crops out in several parts of the Loncoche Ridge (Figs. 1 and 4) (Duhart et al., 2003). They occur at different heights up to $\sim 500 \mathrm{~m}$ a.s.l. The formation overlies the metamorphic basement, and it is only a few tens of meters thick. This unit was tentatively assigned to the Pleistocene by Duhart et al. (2003).

2.2.5.2. Coastal area. The Tubul Formation (Biró-Bagoczky, 1979) is a marine unit that crops out in the Arauco Peninsula-Tirúa area $\left(37^{\circ}-38^{\circ} \mathrm{S}\right.$. Figs. 2, and 6). This unit presents an angular unconformity with Eocene
SALTO DEL LAJA

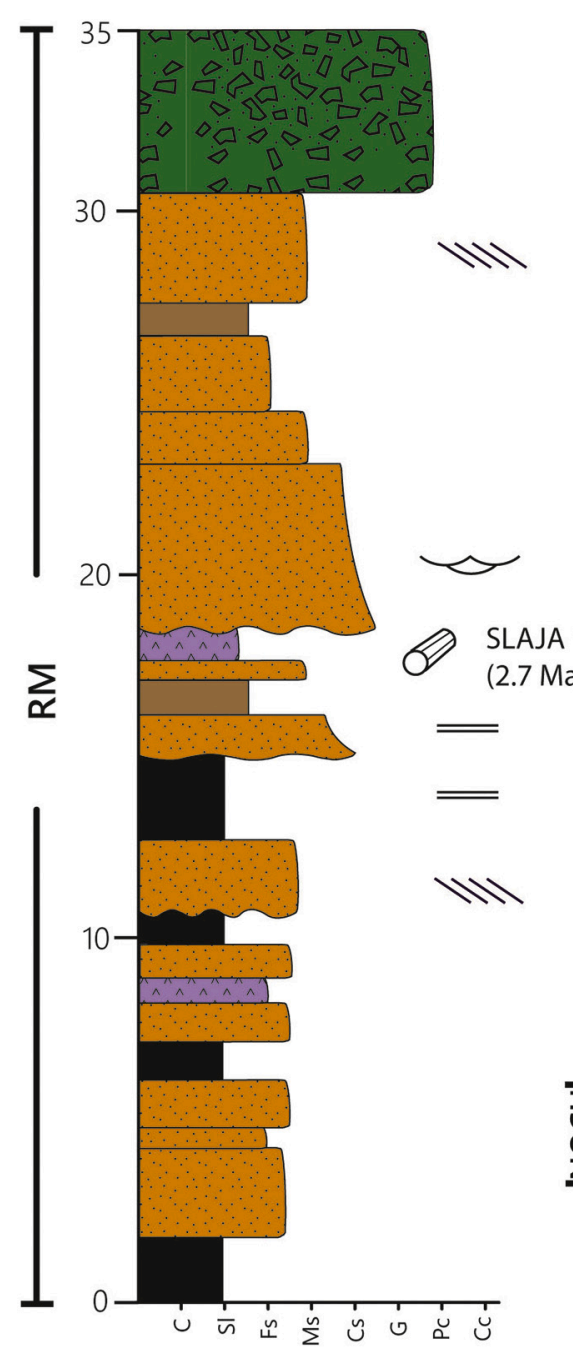

COLLIPULLI
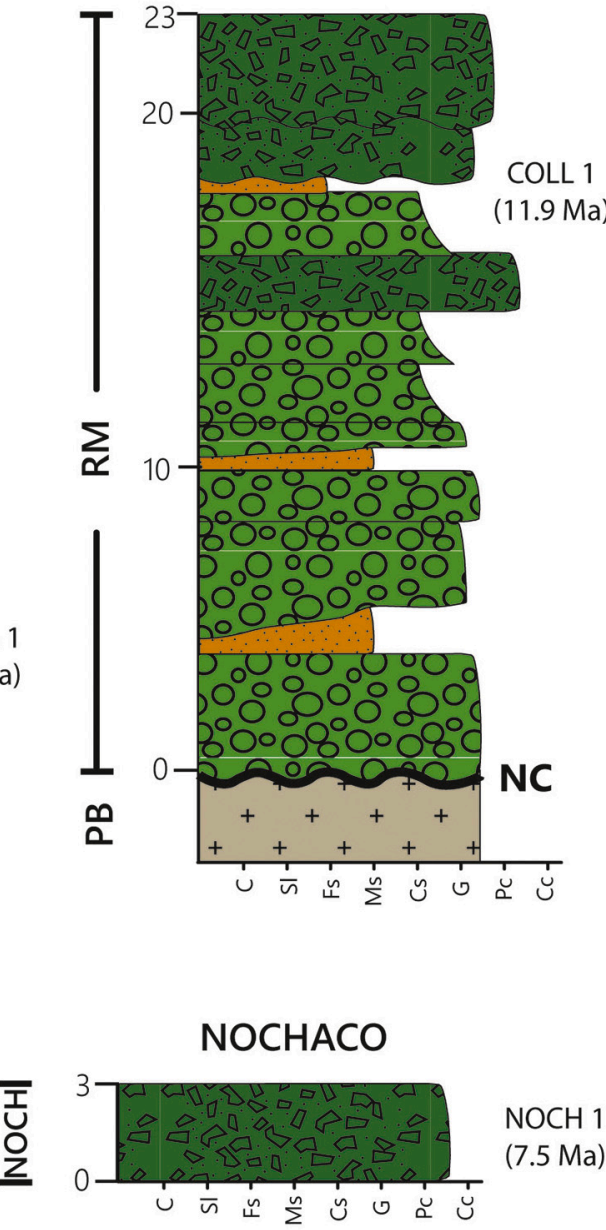

$\mathrm{NOCH} 1$ (7.5 Ma) $.5 \mathrm{Ma}$
QUIAPO

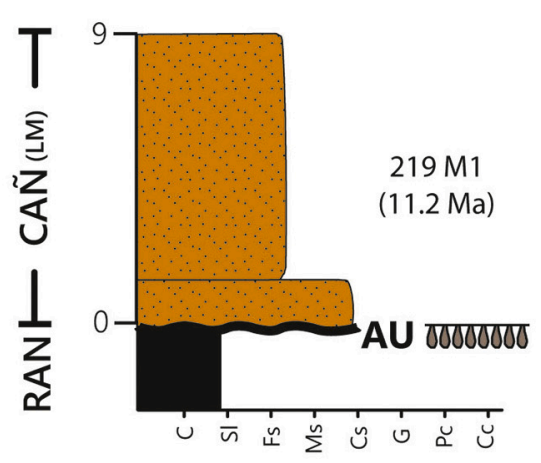

TIRÚA

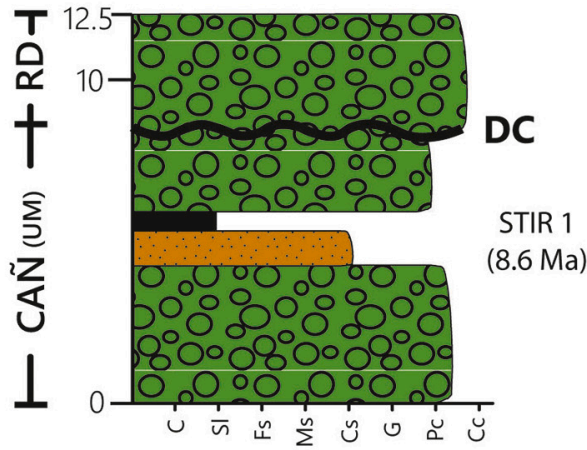

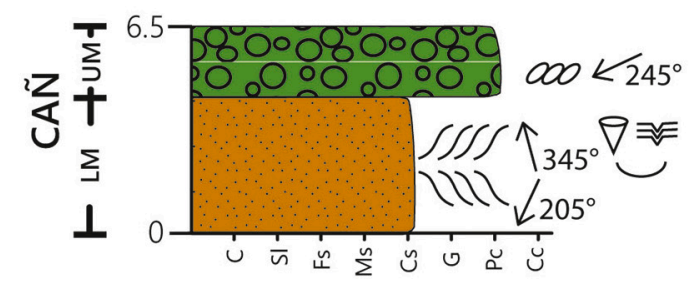

Fig. 9. Representative sections of the Mininco, Rodados Multicolores, and Cañete Formations (continuation of Fig. 9). 
and Upper Oligocene-Lower Miocene marine strata. The Tubul Formation is $\sim 100 \mathrm{~m}$ thick and consists of fossiliferous sandy siltstones (García, 1968; Biró-Bagoczky, 1979. Fig. 7f). Sedimentologic and paleontologic analysis of this unit indicate deposition in a shallowmarine environment (Vargas, 2019). Rojas (2000) assigned an Early Pliocene age to this formation based on the finding of the foraminifer Sphaeroidinella deshicens.

The Cañete Formation (Fig. 6) was defined by Kaizuka et al. (1973) in the Arauco Peninsula $\left(37^{\circ}-38^{\circ} \mathrm{S}\right)$. However, we also identified outcrops of this unit in several parts along the coast between this area and Puerto Saavedra $\left(39^{\circ} \mathrm{S}\right)$, which Pino et al. (2002) correlated with equivalent deposits in the Valdivia area $\left(40^{\circ} \mathrm{S}\right)$, and also near Caleta Huellelhue, southwest of Valdivia ( $41^{\circ} \mathrm{S}$. Fig. 2). The Cañete Formation is up to $\sim 100 \mathrm{~m}$ thick and presents an angular unconformity with Eocene and Miocene marine strata of the Grupo Lebu and Ranquil Formation, and a disconformity with the Pliocene Tubul Formation (Kaizuka et al., 1973). Melnick et al. (2009) divided the Cañete Formation into a lower marine member and an upper fluvial member (Figs. $7 \mathrm{~g}, \mathrm{~h}, \mathrm{i}$, $\mathrm{j}, \mathrm{k}, \mathrm{l}$, and 9). The marine member consists of sandstone and minor siltstone, and the fluvial member is composed of conglomerate, sandstone, and minor siltstone. The upper member of the Cañete Formation transitionally overlies the lower marine member, although in some areas unconformably overlies Eocene marine rocks. This member is very similar to the Rodados Multicolores Formation. In fact, an outcrop of the first unit near Tirúa was correlated with this unit by Rehak et al. (2008). In some localities, the upper Member of the Cañete Formation is disconformaly overlain by recent fluvial deposits that contain metamorphic and plutonic clasts (Fig. 71). The age of the Cañete Formation is PlioPleistocene, as constraint by the Early Pliocene age of the underlying Tubul Formation and the Pleistocene $(\sim 120 \mathrm{ka})$ age attributed to the Cañete surface (Melnick et al., 2009) developed over the Cañete Formation (see section 2.1.1).

\section{This study}

\subsection{Sedimentology of the Mininco, Rodados Multicolores, Nochaco, and Cañete formations}

We analyzed different stratigraphic columns of the Mininco, Rodados Multicolores, Nochaco, and Cañete (Figs. 8, and 9). Outcrops of these units typically occur along.

roadcuts and riverbanks. Sections are typically small and badly preserved, which prevents a refined sedimentologic interpretation.

\subsubsection{Mininco Formation}

The Mininco Formation is composed of sandstones, conglomerates, tuffaceous siltstones, and tuffs (Fig. 8). Conglomerates contain abundant clasts of pumice (Fig. 7a) and scarcer basalt and andesite. Sandstones typically display erosive contacts and through and planar cross-bedding. Tuffaceous siltstones locally present paleosoils as well as leaves and wood debris. Lithic tuffs are typically interbedded with sandstone and tuffaceous siltstones. We interpret the Mininco Formation as deposited by braided and meandering rivers. The occurrence of tuffs and abundant pumice clasts in sandstone beds indicates contemporaneous explosive volcanism.

\subsubsection{Rodados Multicolores Formation}

The Rodados Multicolores Formation consists of conglomerates, sandstones, and minor siltstones and tuffs (Figs. 8 and 9). Conglomerates contain clasts that are typically decimeters long and are composed primarily of volcanic rocks (andesite and basalt) and, more rarely, of granite. They present two different facies: 1) clast-supported conglomerates with well-rounded clasts, and 2) matrix-supported conglomerates with angular clasts and a matrix composed of andesite lithics, plagioclase, quartz, and ash (Fig. 7b, c, d, and e). Paleocurrent analysis from imbricated clasts indicates an approximately west transport direction
(Fig. 8). The upper part of clast-supported conglomerate facies are typically strongly weathered; clasts show soft, weathered rinds and harder, less altered cores (Fig. 7e). Sandstones show planar and trough cross-bedding. They occur as lenses within clast-supported conglomerates or form more continuous successions that locally show intercalations of siltstones and tuffs. Siltstones can contain fossil leaves and paleosoils. In agreement with Hauser (1986), we interpret the Rodados Multicolores Formation as deposited by braided rivers (graveland sandy dominated) with locally interbedded lahar deposits corresponding to the matrix-supported conglomeratic facies. The lower part of the Salto del Laja section (Fig. 9) probably corresponds to a meandering fluvial system as it presents channel and fine-grained floodplain facies associations. The occurrence of tuffs indicates explosive volcanism contemporaneous with fluvial and lahar deposition. In agreement with Thiele et al. (1998), we interpret typical superficial weathering of the Rodados Multicolores Formation as caused by soil development after the end of the sedimentation of this unit.

\subsubsection{Nochaco Formation}

The outcrops of this unit are very scarce and poorly preserved (Fig. 9). The Nochaco Formation consists of conglomerates that contain clasts typically decimeters in size composed of well- to subangular clasts of slate, metasandstone, schist, andesite, and granite. They present two different facies: 1) clast-supported conglomerates with well-rounded clasts, and 2) matrix-supported conglomerates with angular clasts. The Nochaco Formation is likely correlative with the Rodados Multicolores Formation (see section 4.1). We interpret this unit as deposited by gravel-dominated braided rivers with locally interbedded lahar deposits corresponding to the matrix-supported conglomeratic facies.

\subsubsection{Cañete Formation}

The Cañete Formation presents a lower marine Member and an upper fluvial Member (Figs. $7 \mathrm{~g}$, h, and 9). The lower Member consists of sandstone and minor siltstone. We identified a bioturbated horizon with undetermined borings, characteristic of the Glossifungites ichnofacies, in the contact of these units with the Ranquil Formation near Quiapo (Fig. 9). Sandstone presents sigmoidal cross-bedded sandstone with bimodal paleocurrent directions (Figs. $7 \mathrm{~g}$, h, and i), flaser, wavy, and lenticular bedding. Locally contains molds of bivalves (Fig. 7j) and scarce trace fossils of Conichnus (Fig. 7i), Ophiomorpha, and escape trace fossils. The cited facies denote tidal influence and probably indicate an estuarine environment developed during the marine transgression that gave way to the deposition of this member.

The upper member of the Cañete Formation transitionally overlies the lower marine member, although in some localities it directly overlies older rocks. This member consists of conglomerate, sandstone, and minor siltstone (Figs. 7k, 1, and 9). Conglomerates are clast-supported, moderately to well sorted, and contain well-rounded clasts centimeters to, more rarely, decimeters long composed of andesites and minor metamorphic rocks that are commonly weathered. Paleocurrent analysis from imbricated clasts indicates an approximately west transport direction (Fig. 9). Sandstones locally present cross-bedding. Siltstones are scarce and present paleosoils (Fig. 7k). This member is locally covered by recent fluvial deposits bearing clasts derived from the metamorphic basement (Fig. 71). We interpret the upper member of the Cañete Formation as deposited by gravel- and sandy dominated braided rivers.

\section{2. $U-P b$ Geochronology}

\subsection{1. $U-P b$ Geochronology Analytical Method}

The age and provenance of Plio-Pleistocene deposits in the Central Depression and Coastal Cordillera are essential to constraint the tectonosedimentary evolution of these morphostructural units. For this reason, we carried out $\mathrm{U}-\mathrm{Pb}$ geochronology from the Mininco, Rodados Multicolores, Nochaco, and Cañete formations. These units had been tentatively considered as Pliocene or Quaternary (e.g., Muñoz-Cristi, 
1960; Kaizuka et al., 1973; Hauser, 1986) but never properly dated. We analyzed 12 samples, including sandstones (4 samples), sandy siltstones (2 samples), pumice-bearing conglomerates (1 sample), and tuffs (4 samples). Results from the LA-ICPMS zircon $\mathrm{U}-\mathrm{Pb}$ isotope analyses are presented in Table DR1 Figure Supplementary material. In order to determine the depositional ages of the volcanic rocks and maximum depositional ages and zircon provenance from the sedimentary rocks, we analyzed over 50 -and over 100 zircon crystals per sample, respectively. The calculated ${ }^{206} \mathrm{U} /{ }^{238} \mathrm{~Pb}$ Tuff Zirc ages and other age groups are presented in Table 1. Probability density age distribution and Tuffzirc age plots are presented in Figs. 10 and 11. The geographic location of the
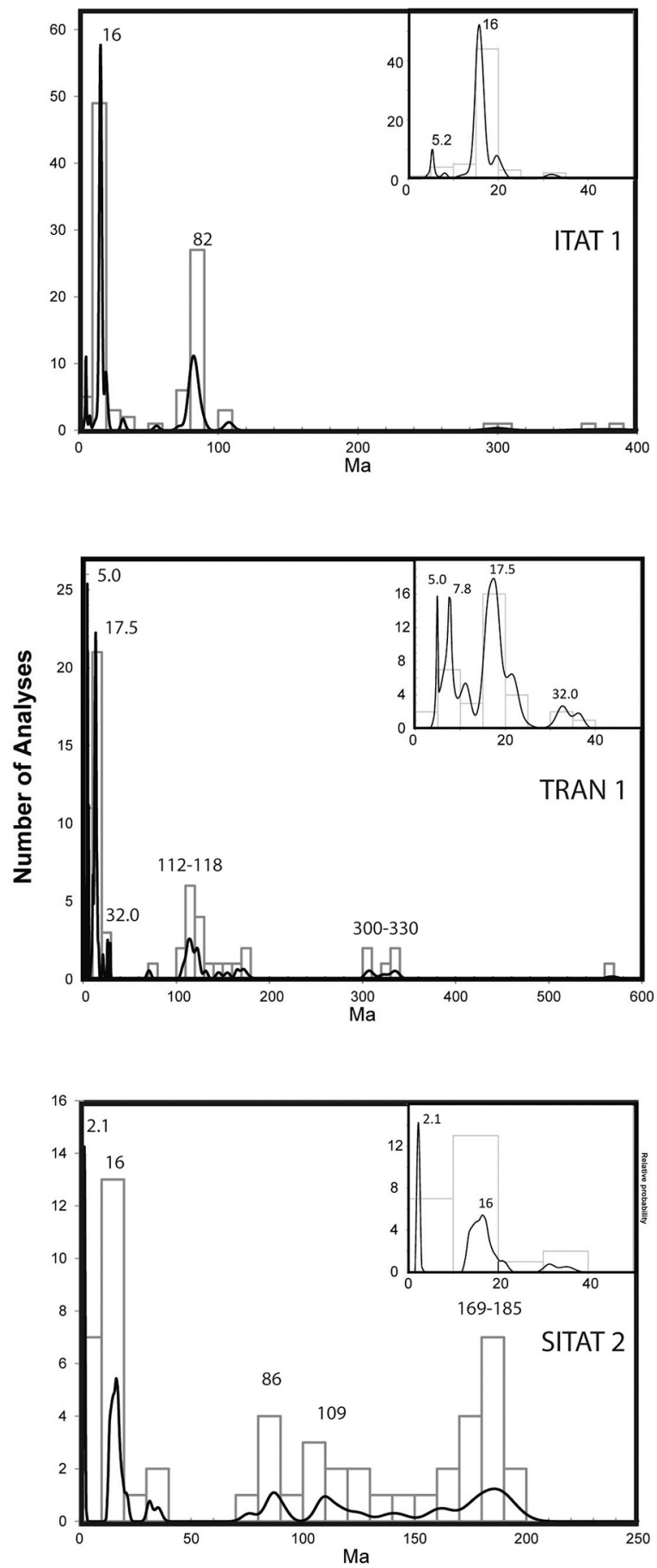

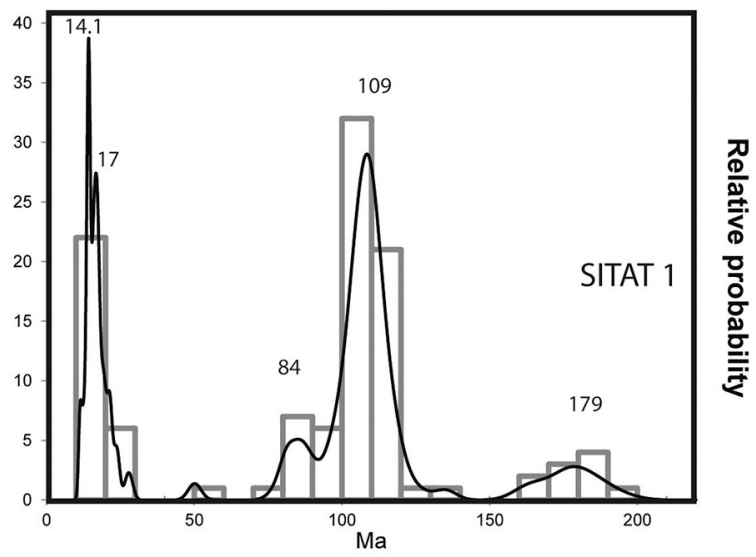

samples is indicated in maps from Figs. 3, 4, and 5. The location of samples in stratigraphic columns is indicated in Figs. 8, and 9.

Zircon concentrates from all samples were separated at Zirchron LLC laboratory in Tucson, Arizona. Each sample was individually unpacked and pressure washed with water to remove any debris and/or foreign materials. Sample rock fragments were placed in the sample chamber of an Electro Pulse Disaggregator (EPD, Marx generator), and electrical pulses were applied at $1-2 \mathrm{~Hz}$ repetition and discharges of $\sim 220 \mathrm{kV}$ for $15 \mathrm{~min}$. The material, sized between $500 \mu$ and $25 \mu$, was then processed using traditional methods using the Wilfley water table, Frantz paramagnetic separator, and one-step $(3.32 \mathrm{~g} / \mathrm{cc})$ heavy liquid MEI
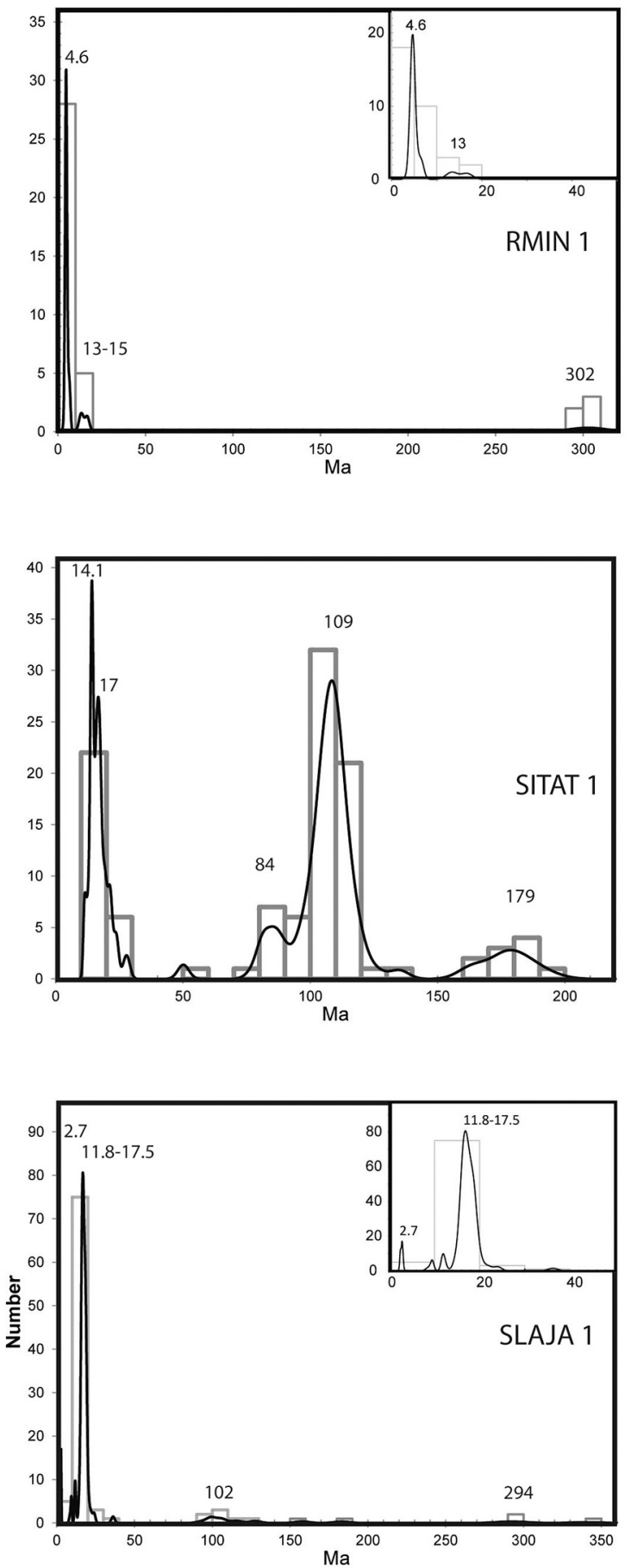

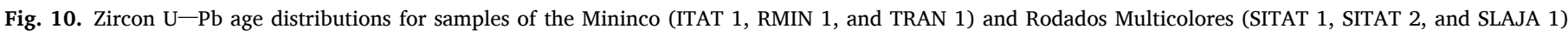

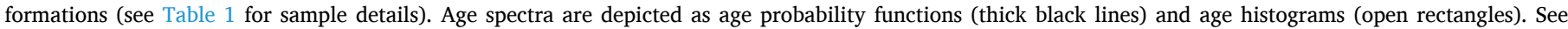
geographic and stratigraphic location of samples in Figs. 3, 5, 8, and 9. 

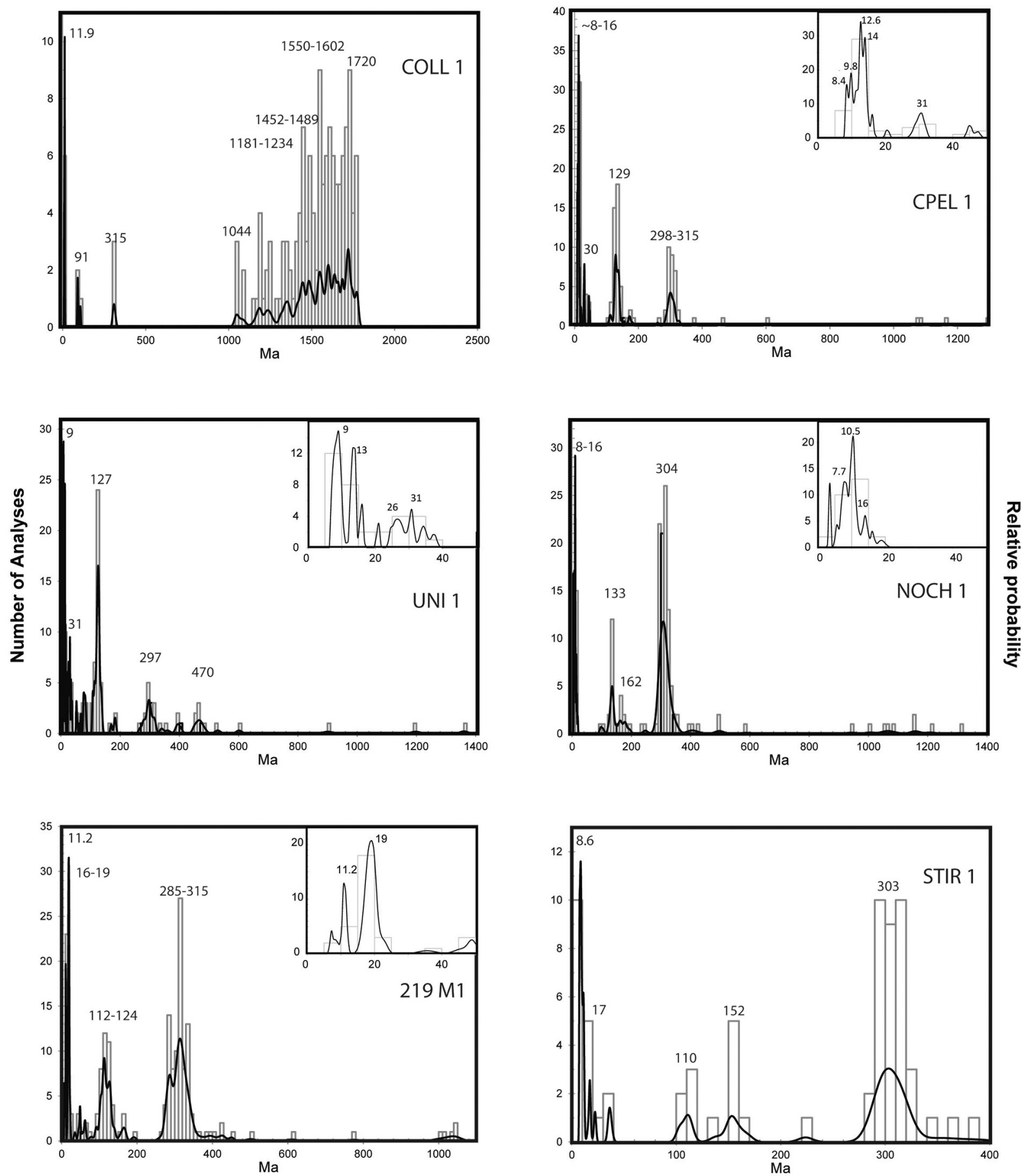

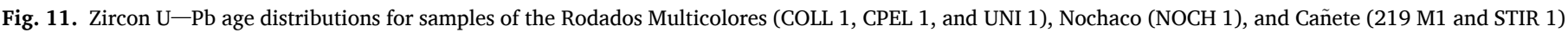

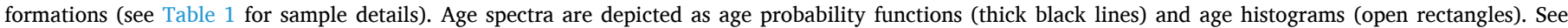
geographic and stratigraphic location of samples in Figs. 3, 4, 5, 8, and 9.

separation. Zircons from the non-magnetic fraction were mounted with standards in a 1-in. diameter epoxy puck and polished using standard laboratory procedures.

After cathodoluminescence imaging, $\mathrm{U}-\mathrm{Pb}$ analyses were conducted using laser ablation ICP-MS. An Analyte G2 193nm excimer laser was connected to the Element2 high resolution inductively coupled plasma mass spectrometer. For the $\mathrm{U}-\mathrm{Pb}$ measurement, we mostly followed the method of Chang et al. (2006), except the use of the $193 \mathrm{~nm}$ laser instead of the $213 \mathrm{~nm}$ laser in the Chang et al. (2006) study. The laser parameters were $35 \mathrm{um}$ spot size, $10 \mathrm{~Hz}$ repetition rate with $\sim 4 \mathrm{~J} / \mathrm{cm} 2$ power for the $\mathrm{U}-\mathrm{Pb}$ analysis. A 30-s blank measurement of He and Ar carrier gasses (laser off) before each analysis was used to measure background, followed by 250 scans across masses $202 \mathrm{Hg}, 204 \mathrm{~Pb}+\mathrm{Hg}, 206 \mathrm{~Pb}, 207 \mathrm{~Pb}$, $208 \mathrm{~Pb}, 232 \mathrm{Th}, 235 \mathrm{U}$, and $238 \mathrm{U}$ during $\sim 30 \mathrm{~s}$ laser ablation period. Data were processed offline using the Iolite software (Paton et al., 2010). $\mathrm{He}$ and Ar carrier gases delivered the sample aerosol to the plasma. Each analysis consisted of a short blank analysis followed by 250 sweeps through masses 202, 204, 206, 207, 208, 232, 235, and 238, taking approximately $30 \mathrm{~s}$ in all. Unknowns were run in blocks of 10 analyses bracketed by standards. Time-independent fractionation was corrected 
Table 1

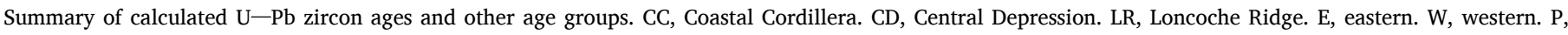
Peninsula.

\begin{tabular}{|c|c|c|c|c|c|}
\hline Sample & Formation & Lithology & Location & Maximum Age of Deposition (Ma) & Other age peaks (Ma) \\
\hline ITAT 1 & Mininco & Pumice conglomerate & $\operatorname{ECD} 36^{\circ} 30^{\prime} \mathrm{S}$ & $5.3+0.3-0.6$ & $16,82,108$ \\
\hline RMIN 1 & Mininco & Tuff & $\mathrm{CD}, 38^{\circ} \mathrm{S}$ & $4.5+0.1-0.4$ & $13-15,302$ \\
\hline TRAN 1 & Mininco & Tuff & $\mathrm{ECD} 40^{\circ} 10^{\prime} \mathrm{S}$ & $5 \pm 0.5$ & $14,29,112-118,300-330$ \\
\hline SITAT 1 & Rodados Multicolores & Sandstone & $\mathrm{CD}, 37^{\circ} \mathrm{S}$ & $14.1+0.2-0.5$ & $14-17,84,109,179$ \\
\hline SITAT 2 & Rodados Multicolores & Tuff & $\mathrm{CD}, 37^{\circ} \mathrm{S}$ & $2.1 \pm 0.1$ & $16,86,109,169,185$ \\
\hline SLAJA 1 & Rodados Multicolores & Tuff & $\mathrm{CD}, 37^{\circ} 12^{\prime} \mathrm{S}$ & $2.7 \pm 0.7$ & $12-17,102,294$ \\
\hline COLL 1 & Rodados Multicolores & Sandy siltstone & $\mathrm{CD}, 38^{\circ} \mathrm{S}$ & $11.9+0.6-0.3$ & $91(2), 315$, several groups between 1044 and 1720 \\
\hline CPEL 1 & Rodados Multicolores & Sandstone & ECC $40^{\circ} 12^{\prime} \mathrm{S}$ & $8.3+0.3-0.03$ & $8-16,30,129,298-315$ \\
\hline UNI 1 & Rodados Multicolores & Sandstone & WCD $40^{\circ} 19^{\prime} \mathrm{S}$ & $8.8 \pm 0.2$ & $31,127,297,470$ \\
\hline NOCH 1 & Nochaco & $\begin{array}{l}\text { Conglomeratic } \\
\text { Sandstone }\end{array}$ & LR, CD $39^{\circ} 45^{\prime} \mathrm{S}$ & $7.5+0.2-0.4$ & $3.4(2), 8-16,133,162,304$ \\
\hline 219 M 1 & Cañete & Sandstone & Arauco P. $37^{\circ} 30^{\prime} \mathrm{S}$ & $11.2+0.2-0.6$ & $16-19,49,112-124,285-315$ \\
\hline STIR 1 & Cañete & Sandy siltstone & WCC $38^{\circ} 25 ’ s$ & $8.6+0.3-0.4$ & $17,110,152,303$ \\
\hline
\end{tabular}

by normalizing $\mathrm{U} / \mathrm{Pb}$ and $\mathrm{Pb} / \mathrm{Pb}$ ratios of the unknowns to the zircon standards (Chang et al., 2006). U and Th concentrations were monitored by comparing to 91,500 zircon standard. Plesovice (Sláma et al., 2008) and FC-1 (Paces and Miller, 1993), and Fish Canyon Tuff, with an age of 28.4 Ma (Schmitz and Bowring, 2001) were used as zircon standards. Common Pb corrections were using the 207Pb method (Williams, 1998). $\mathrm{U}-\mathrm{Pb}$ diagrams and ages were calculated using Isoplot (Ludwig, 2003). Interpreted ages are based on $206 \mathrm{~Pb} / 238 \mathrm{U}$ for $<1200$ Ma grains and on $206 \mathrm{~Pb} / 207 \mathrm{~Pb}$ for $>1200 \mathrm{Ma}$ grains. U- $\mathrm{Pb}$ zircon maximum deposition age errors are reported using the quadratic sum of the analytical error plus the total systematic error for the set of analyses (Valencia et al., 2005). The interpretations for detrital zircons are based on the definition of representative populations, which are represented by three or more overlapping zircon ages (Gehrels et al., 2006). The maximum depositional age was calculated using the TuffZirc algorithm (Ludwig, 2003) from the youngest cluster $(>6)$ of overlapping ages. Zircons from these samples are clear and colorless and display a variety of morphologies but are mainly long euhedral crystals dominated by prominent bi-pyramidal Terminations. minor proportions of subhedral to subrounded zircon crystals are present. Cathodoluminescence images revealed a simple growth history (oscillatory to sector zoning) (Fig. DR1).

\subsubsection{Results}

We collected three samples from the Mininco Formation, two from the northern part of the study area (ITAT1 and RMIN1) and one from the central-southern part (TRAN1). Sample ITAT1 is a pumice conglomerate that overlies Carboniferous-Permian granites and crops out in the limit between the Central Depression and the Coastal Cordillera at $\sim 36^{\circ} 30^{\prime} \mathrm{S}$. Sample RMIN1 is a tuff interbedded in a succession of sandstone and siltstone that crops out in the type area of the Mininco Formation in the Central Depression near Collipulli $\left(\sim 38^{\circ} \mathrm{S}\right)$. The contact of this unit with the granitic basement was observed near the sample locality. Sample ITAT1 yielded a maximum depositional age of $5.3+0.3-0.6 \mathrm{Ma}$ and other peaks at 16, 82, 108 Ma. Sample RMIN1 yielded an age of $4.5+$ $0.1-0.4 \mathrm{Ma}$ and other zircon groups of 13-15, $302 \mathrm{Ma}$. Sample TRAN1 is a lithic tuff exposed in the limit between the Central Depression and the Coastal Cordillera at $\sim 40^{\circ} 10^{\prime} \mathrm{S}$. This sample yielded an age of $5 \pm 0.5 \mathrm{Ma}$ and older peaks of 14, 29, 112-118, and 300-330 Ma.

We analyzed 6 samples from the Rodados Multicolores Formation, four from the northern part of the study area in the Central Depression (SITAT1, SITAT2, SLAJA1, and COLL1) and two from the centralsouthern part (CPEL1, and UNI1) in the Coastal Cordillera and Central Depression respectively. Sample SITAT1 is a sandstone collected from a succession of conglomerates, sandstones, and tuffs that crops out in the Itata River banks, and SITAT2 is a tuff from the same section $\left(37^{\circ} \mathrm{S}\right)$. Sample SLAJA1 is a tuff from a succession of sandstones, siltstones, conglomerates, and tuffs that crop out in the banks of the Laja River $\left(37^{\circ} 12^{\prime} \mathrm{S}\right)$. Sample COLL1 is sandy siltstone interbedded in a conglomerate succession that overlies the Mininico Formation from a roadcut at
Collipulli $\left(38^{\circ} \mathrm{S}\right)$. Sample SITAT1 yielded a maximum age of $14.1+$ $0.2-0.5 \mathrm{Ma}$ and zircon groups of 14-17, 84, 109, 179 Ma. Sample SITAT2 yielded an age of $2.1 \pm 0.1 \mathrm{Ma}$ and peaks of $16,86,109,169$, $185 \mathrm{Ma}$. Sample SLAJA1 yielded an age of $2.7 \pm 0.7 \mathrm{Ma}$ and zircon groups of 12-17, 102, $294 \mathrm{Ma}$. Sample COLL1 yielded a maximum age of $11.9+0.6-0.3 \mathrm{Ma}$ and peaks of 91(2), 315, and several zircon groups between 1044 and 1720 Ma. Regarding samples from the centralsouthern part of the study area, CPEL1 is a sandstone collected from a small outcrop of conglomerates and minor sandstones overlying the metamorphic basement in the eastern flank of the Coastal Cordillera at $40^{\circ} 12^{\prime} \mathrm{S}$ and an elevation of $624 \mathrm{~m}$ a.s.l. Sample UNI1 is also a sandstone from a mostly conglomeratic succession, presumably overlying OligoMiocene strata. This sample is located in a roadcut of the Central Depression $25 \mathrm{~km}$ to the SE of CPEL1, and at an elevation of $33 \mathrm{~m}$ a.s.l. Sample CEPL1 yielded a maximum age of 8.3+0.3-0.03 Ma and other peaks of 8-16, 30, 129, and 298-315 Ma. Sample UNI1 shows similar dates with a maximum age of $8.8+0.2 \mathrm{Ma}$ and other zircon groups of 31, 127, 297, and $470 \mathrm{Ma}$.

We analyzed one sample of conglomeratic sandstone from the Nochaco Formation (sample NOCH1). The succession is mostly conglomeratic, overlies the metamorphic basement, and crops out in the Loncoche ridge at $\sim 39^{\circ} 45^{\prime} \mathrm{S}$ and $\sim 400 \mathrm{~m}$ a.s.l. Sample NOCH1 yielded a maximum age of $7.5+0.2-0.4 \mathrm{Ma}$, although it contains two zircon grains of 3.4 Ma that suggest a younger age. Other zircon groups have ages of $8-16,133,162$, and $304 \mathrm{Ma}$.

Finally, we analyzed two samples from the Cañete Formation, one in the Arauco Peninsula (219 M1), and the second near Tirúa (STIR1). Sample 219 M1 is marine sandstone from a roadcut north of Lebu $\left(37^{\circ} 30^{\prime} \mathrm{S}\right)$ that yielded a maximum age of $8.6+0.3-0.4 \mathrm{Ma}$ and other peaks of 17, 110, 152, and $303 \mathrm{Ma}$. Sample STIR1 is sandy siltstone interbedded in a fluvial conglomeratic succession that crops out in a roadcut south of Tirúa $\left(38^{\circ} 25^{\prime} \mathrm{S}\right)$. This sample yielded a maximum age of $11.2+0.2-0.6 \mathrm{Ma}$ and zircon groups of 16-19, 49, 112-124, 285-315.

\subsection{Geomorphologic, stratigraphic, and structural characteristics of the Coastal Cordillera and Central Depression}

\subsubsection{Coastal Cordillera}

Rehak et al. (2008), based on geomorphologic analysis, noted that the Coastal Cordillera of south-central Chile presents two uplifted areas with an asymmetrical dome-like morphology separated by a lowelevation area (see chapter 2.1.1). The geological configuration of the Coastal Cordillera also reflects this segmentation. Upper PaleozoicLower Mesozoic metamorphic and plutonic rocks typically occur in the axial, highest parts of the Nahuelbuta and Bueno segments (Figs. 2, $3,5,12$, and 13). Cenozoic strata are usually restricted to the flanks of these asymmetrical dome-like structures. Upper Oligocene-Lower Miocene continental and marine strata typically reach elevations up to $400 \mathrm{~m}$ a.s.l whereas Plio-Pleistocene continental deposits commonly 


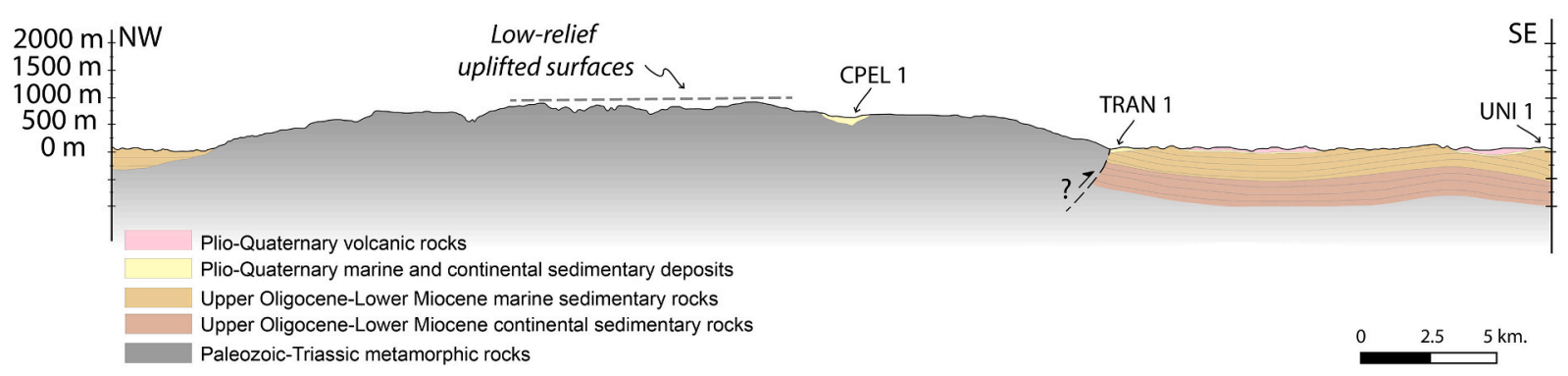

Fig. 12. Schematic structural profile in the northern part of the Bueno segment (see Fig. 5 for location) showing the interpretation of the main structures at depth based on field, seismic and borehole data (see Elgueta et al., 2000). The location of U/Pb zircon samples CPEL1, TRAN1, and UNI1 are shown. Note the occurrence of an uplifted outcrop of the Rodados Multicolores Formation (CPEL1) in the eastern part of the Coastal Cordillera.

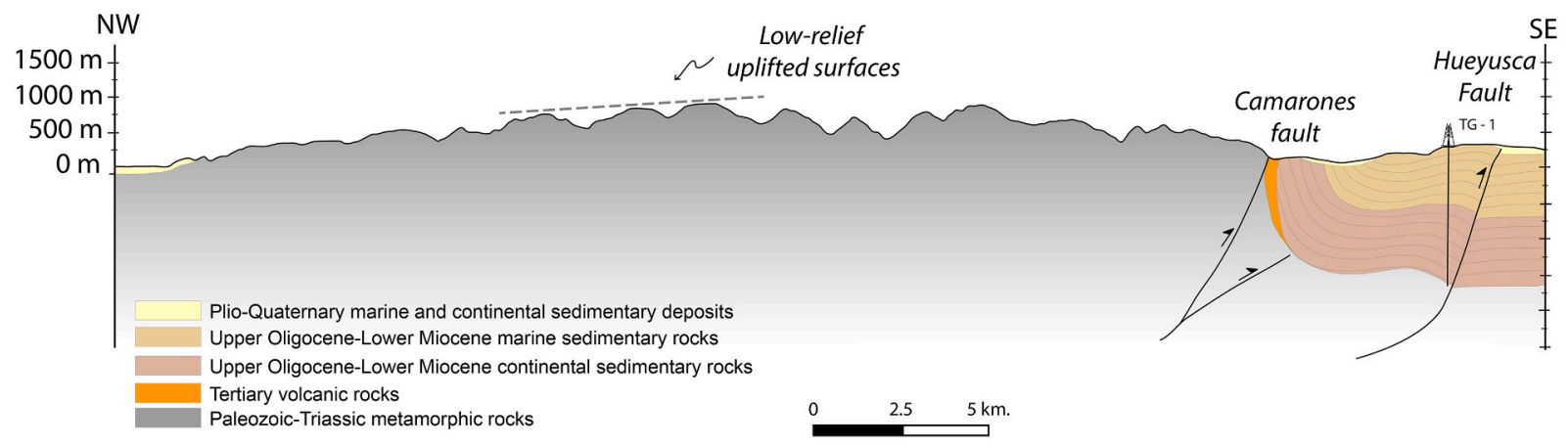

Fig. 13. Schematic structural profile in the southern part of the Bueno segment (see Fig. 5 for location) showing the interpretation of the main structures at depth based on field, seismic and borehole data. The eastern part of the profile transects the Camarones and Hueyusca faults as well as the Tegualda 1 (TG-1) ENAP well and the seismic line CD-010 (see Fig. 16).

crop out at lower heights of only $100 \mathrm{~m}$ a.s.l. However, Oligo-Miocene continental and marine rocks locally occur in axial parts of the Bueno segment, such as near Bahía Mansa $\left(40^{\circ} 30^{\prime} \mathrm{S}\right)$ and Llico Bajo $\left(\sim 41^{\circ} \mathrm{S}\right)$, where they reach altitudes up to $\sim 500 \mathrm{~m}$ a.s.l. (Fig. 5). Noteworthy, we also found several outcrops of the Plio-Pleistocene Rodados Multicolores Formation overlying basement metamorphic rocks in the northern part of the Bueno segment at different altitudes up to $624 \mathrm{~m}$ a.s.l. (sample CPEL1. Figs. 5, and 12). Approximately $25 \mathrm{~km}$ to the SE, an outcrop of this formation reaches only $33 \mathrm{~m}$ a.s.l. (sample UNI1). Overall, the geological configuration of the Nahuelbuta and Bueno segments suggest that they are large, double plunging anticlines where older rocks crop out principally in the axial parts, and younger Cenozoic strata occur typically in the flanks.

The Toltén segment shows a less orderly geological distribution (Figs. 2, and 4). Paleozoic-Triassic metamorphic rocks typically occur in the highest hills of this area, whereas Oligocene-Lower Miocene and Pliocene-Pleistocene deposits are usually restricted to lower areas. PlioPleistocene deposits commonly occur at maximum heights of $\sim 100 \mathrm{~m}$ a. s.l. in this area and crop out across the entire forearc.

Remnants of a low-relief surface characterize the most elevated areas of the Nahuelbuta and Bueno segments (Figs. 1, 3, 5, 12, 13, 14 a,b,c,d, and 15). This surface is carved mainly on Paleozoic-Triassic metamorphic and plutonic rocks and Upper Oligocene-Lower Miocene continental strata at $41^{\circ} \mathrm{S}$, near Llico Bajo (Fig. 5). The origin of this surface is uncertain. Its maximum age is determined by the cited Upper Oligocene-Lower Miocene continental rocks (the youngest rocks cut by the surface), although Kaizuka et al. (1973) tentatively proposed a PlioPleistocene age for the low-relief surface in the highest part of the Nahuelbuta Mountains.

The eastern flank of the Coastal Cordillera has different characteristics depending on the area. It typically shows a smooth topographic transition with the Central Depression (Figs. 3, 4, and 5). In some areas, the contact between these morphostructural units is rather irregular, with flat entrants of the Central Depression filled with Plio-Pleistocene deposits that end abruptly against the hills of the Coastal Cordillera. In this regard, a particularly interesting area is the Purén basin, an intermontane depression in the Nahuelbuta segment with a triangular shape and is limited by two NW and SW lineaments interpreted by Melnick et al. (2009) as reverse faults (Fig. 3). The inferred faults juxtapose metamorphic and plutonic basement rocks with Tertiary and Plio-Pleistocene deposits that crop out in the depressed area. Other areas show instead abrupt, straight limits between the Coastal Cordillera and the Central Depression. One of these sharp limits corresponds to a reverse fault known as the Camarones Fault (McDonough et al., 1997. Figs. 5, 13, and 15). The fault is located in the eastern limit of the Bueno segment at $\sim 41^{\circ} \mathrm{S}$, has a NE-SW orientation, overthrusts PaleozoicTriassic metamorphic rocks over Oligo-Miocene strata, and shows well-developed triangular facets (Fig. 15). The fault contact is covered. West of the fault, Paleozoic-Triassic metamorphic rocks crop out across the Coastal Cordillera, reaching maximum altitudes of $\sim 800 \mathrm{~m}$ a.s.l. Remnants of well-developed planar surfaces characterize these elevated areas (Figs. 5, 13, 14c, and 15). East of the fault, a succession of vertical strata includes, from west to east, Upper Oligocene-Lower.

Miocene volcanic, continental, and marine rocks (Figs. 5, and 13). Cenozoic strata reach maximum heights of $\sim 100 \mathrm{~m}$ a.s.l. in this area.

The CD-010 seismic line of ENAP (The Chilean National Petroleum Company) is located $\sim 10 \mathrm{~km}$ east of the Camarones Fault and shows another reverse fault (the Hueyusca Fault; McDonough et al., 1997) parallel to the latter (Fig. 16). The fault has a high-angle plane with an eastward vergence and a lystric geometry. In the hanging wall, the Cenozoic succession is deformed into a long wavelength, faultpropagation fold. The Hueyusca fault and smaller reverse faults to the east (Fig. 16) are likely part of the same structural system as the Camarones Fault to the west. The Tegualda1 ENAP well was drilled in this area and transected $91 \mathrm{~m}$ of Plio-Quaternary deposits and $2553 \mathrm{~m}$ of marine and continental Oligo-Miocene strata (Céspedes and Johnson, 

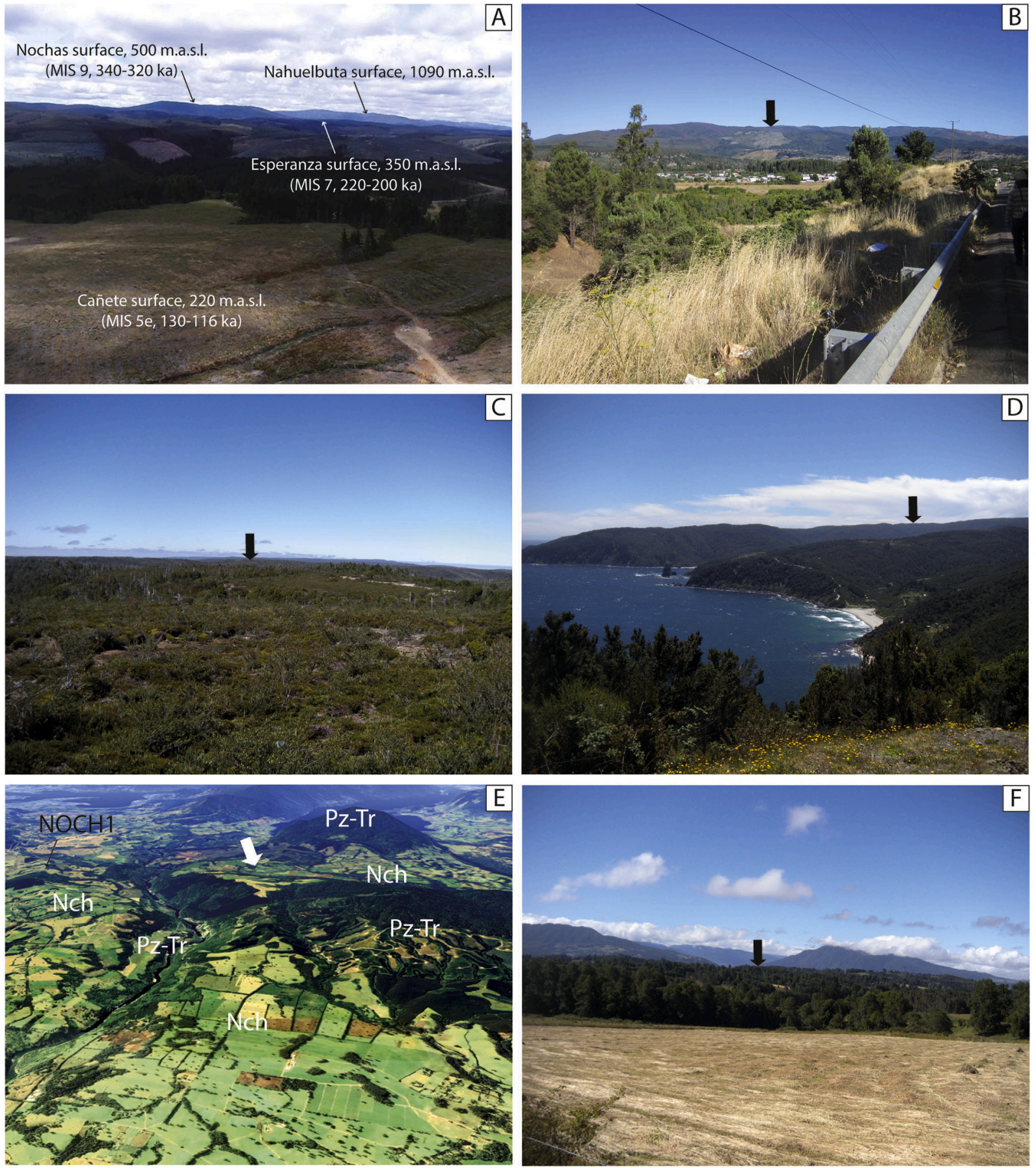

Fig. 14. a) Drone photograph of the Cañete, Esperanza, Nochas, and Nahuelbuta surfaces. View to the east from the central part of the Arauco Peninsula. b) Nahuelbuta upper surface (indicated by arrow). View to the west from the road between Collipulli and Angol. c) Low-relief surface (indicated by arrow) in the upper part of the Coastal Cordillera west of the Camarones Fault. d) Same surface (?) at lower altitude in the Pacific coast of Bahía San Pedro. The surface is tilted to the west. View to the north. e) Oblique Google Earth photo of the Loncoche Ridge area. View to the east. Note that the conglomerates of the Nochacho Formation (Nch) typically cover planar elevated surfaces (one of them indicated by arrow) that abut against higher hills made of Paleozoic-Triassic metamorphic rocks (Pz-Tr). The location of zircon sample NOCH1 is indicated. f) Detail of the cited planar elevated surfaces (indicated by arrow) and higher hills in the background of the picture. Loncoche ridge area. See localities in Figs. 3, 4, and 5.

1984. Figs. 5, 13, and 16). The contact between the metamorphic basement and Cenozoic rocks is located at $2312 \mathrm{~m}$ below sea level. The patchy occurrence of Oligo-Miocene rocks in some areas of the Bueno segment indicates that these strata likely covered the metamorphic basement west of the Camarones Fault and were eroded after the uplift of that area. If this notion is correct, a minimum vertical throw of 3112 $\mathrm{m}$ for this fault can be inferred.

\subsubsection{Central Depression}

The Central Depression is a low-relief area located between the Coastal and the Andean Cordilleras. Basement rocks consist principally of Upper Paleozoic-Permian granitoids and Upper Paleozoic-Triassic metamorphic rocks (Sernageomin, 1998). Oligocene-Lower Miocene volcanic, continental, and marine rocks overlie the basement and reach a thickness of up to $\sim 2500 \mathrm{~m}$ (Muñoz et al., 2000; Elgueta et al., 2000; Encinas et al., 2018). These rocks show evidence of syn-extensional 


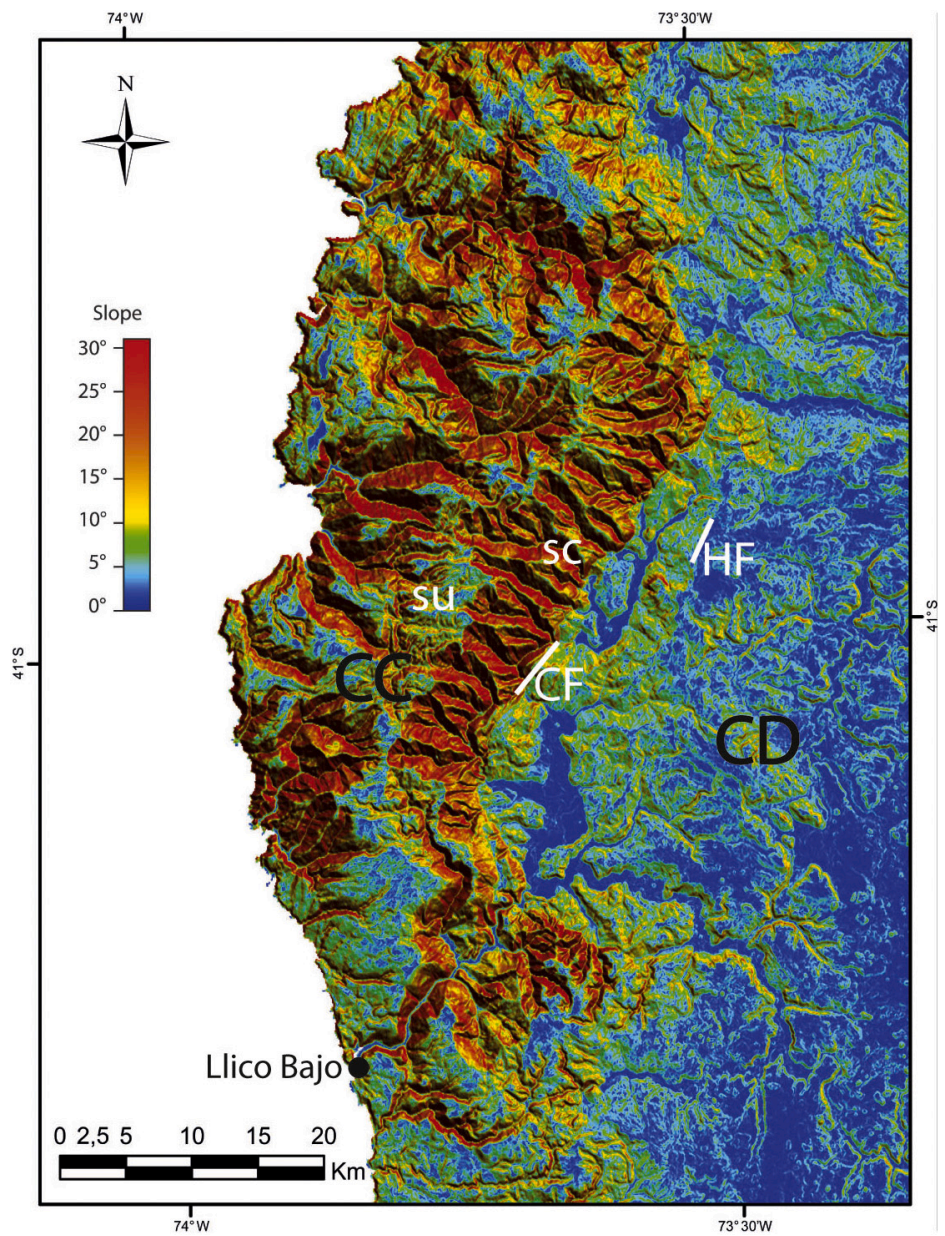

Fig. 15. Local slope map of the Bueno segment computed from SRTM v4.1 digital elevation model (Jarvis et al., 2008). Note the marked scarp (sc) of the Camarones Fault (CF) and the triangular facets at its toe (see Fig. 5 to see the complete fault trace). Also, note the low slope of the elevated surfaces (one of them marked as "su") that are deeply incised by local rivers. HF, Hueyusca Fault. CC, Coastal Cordillera. CD, Central Depression.
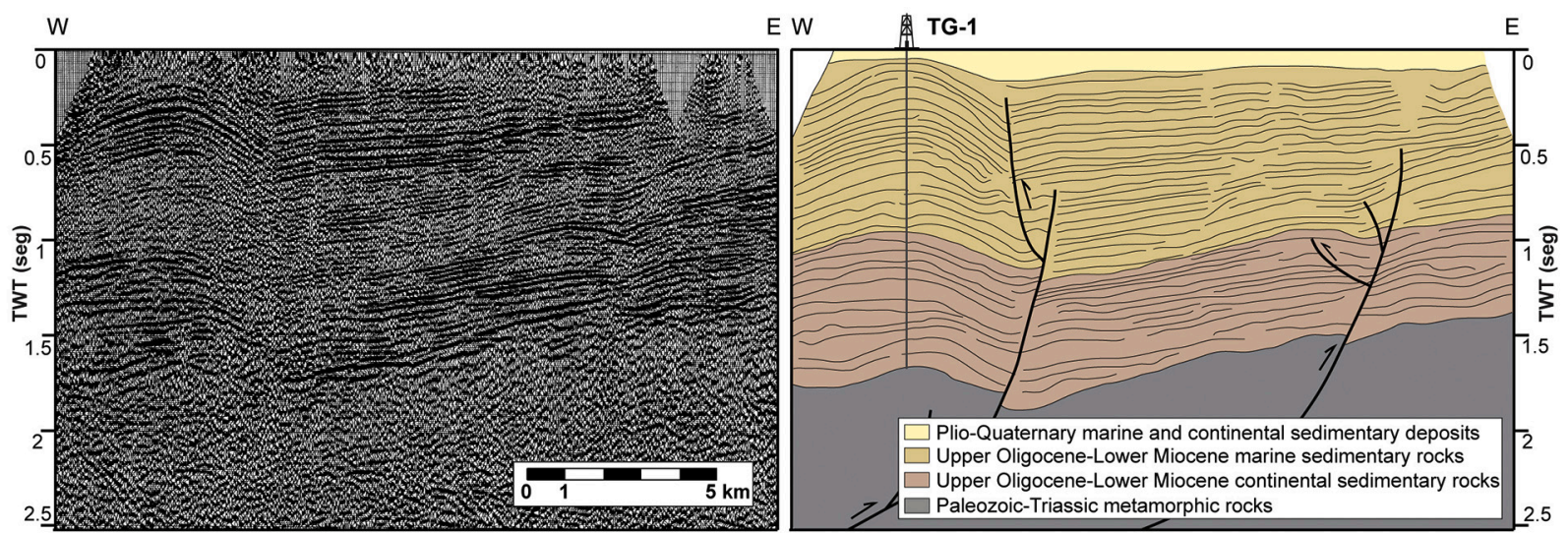

Fig. 16. Multichannel 2D seismic line CD-O10 of ENAP in the western Central Depression, near the limit with the Coastal Cordillera (see Fig. 5 for location). Cenozoic strata and the metamorphic basement are deformed by an east-vergent thrust known as the Hueyusca fault. Note another reverse fault to the east that is part of the same structural system. TG-1: Tegualda 1 ENAP well.

deformation and subsequent tectonic inversion, as indicated by seismic lines (Elgueta et al., 2000; Jordan et al., 2001).

Plio-Pleistocene horizontal continental deposits of the Mininco and Rodados Multicolores formations are the most extensive rocks in the Central Depression. Younger (late Pleistocene) glacial deposits accumulated in the southern part of the study area (Mercer, 1976; Porter, 1981). Plio-Pleistocene deposits fill an irregular paleo-relief carved on
Oligo-Miocene and older rocks as indicated by information obtained from seismic lines, wells, and outcrops (e.g., García, 1968; Elgueta et al., 2000). For that cause, they have highly variable thicknesses that increase to the east, reaching $\sim 2250 \mathrm{~m}$ in the Puerto Montt well (Figs. 5, and 17).

The Central Depression of south-central Chile typically has a flat relief with altitudes around $100-200 \mathrm{~m}$ a.s.l. However, there are also 


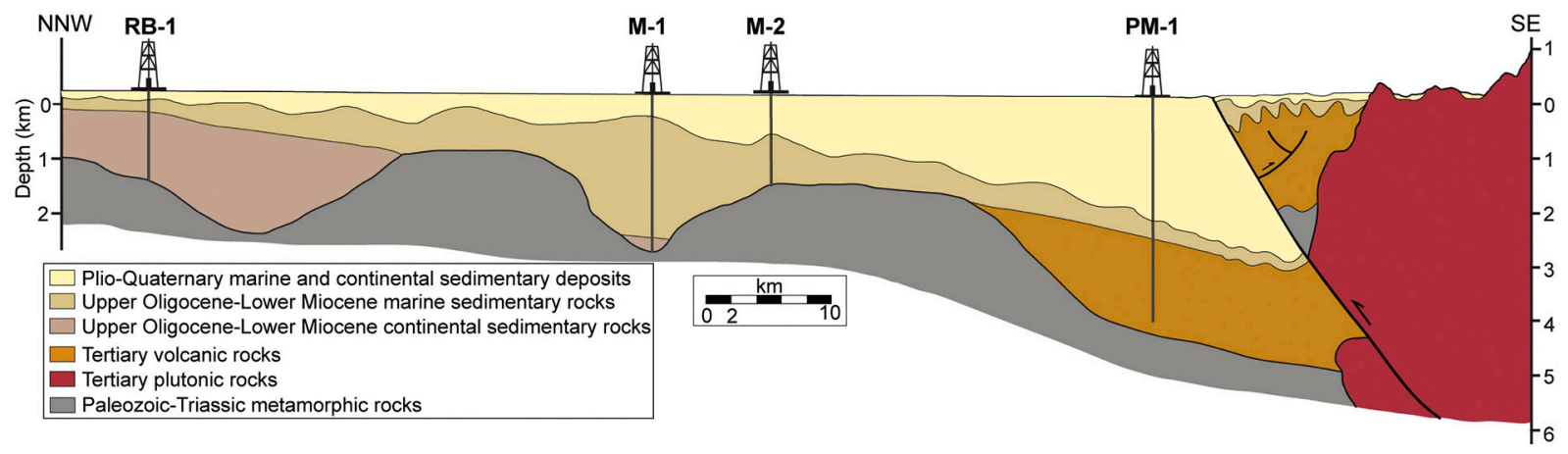

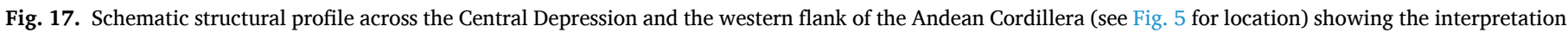

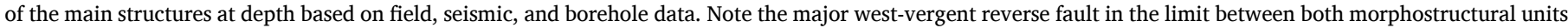

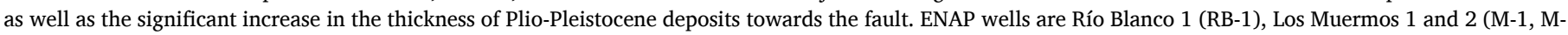
2), and Puerto Montt 1 (PM-1). Wells stratigraphy is from Céspedes and Johnson (1984).

hilly areas composed of Paleozoic-Triassic and Oligocene-Miocene rocks that reach elevations up to $\sim 800 \mathrm{~m}$ a.s.l. (Figs. 3, 4, and 5). Near Los Ángeles city $\left(37^{\circ} 30^{\prime} \mathrm{S}\right)$, several small isolated hills of the cited rocks are surrounded by Plio-Pleistocene deposits (Fig. 3). However, the most significant high-relief area is known as Loncoche Ridge. This range has a $\sim$ NE-SW trend and transects the Central Depression joining the Coastal and Andean Cordilleras at $\sim 39^{\circ}-40^{\circ} \mathrm{S}$ reaching altitudes up to $\sim 800 \mathrm{~m}$ a. s.l. (Figs. 1, and 4). Paleozoic-Triassic metamorphic rocks are the most extensive in this area and reach the maximum heights (Duhart et al., 2003; Quiroz et al., 2007). Upper Oligocene-Lower Miocene continental and marine rocks crop out at lower elevations. Plio-Pleistocene conglomerates of the Nochaco Formation occur in several parts of the Loncoche ridge at different heights up to $500 \mathrm{~m}$ a.s.l. where they cover elevated planar surfaces that abut against higher hills made of PaleozoicTriassic metamorphic rocks (Figs. 4, 14e, and f).

\section{Discussion}

\subsection{Cenozoic tectono-sedimentary evolution of the forearc}

Zircon and apatite fission-track data obtained by Glodny et al. (2008) in the present Coastal Cordillera of south-central Chile $\left(36^{\circ}-42^{\circ} \mathrm{S}\right)$ indicate very slow exhumation in this area since $\sim 200$ Ma (see chapter 2.1.1). The sedimentary record indicates subsequent intervals of uplift and subsidence, but these events did not lead to exhumation detectable by the apatite fission-track method (Glodny et al., 2008). Sedimentary and igneous activity was scarce in the forearc during the Mesozoic and the early Cenozoic until the Oligocene-early Miocene. In this period, an important event of extensional tectonics during the Oligocene-early Miocene resulted in the genesis of a series of basins that extended from the present Chilean coast to the retroarc in Argentina between $\sim 33^{\circ}$ and $46^{\circ} \mathrm{S}$ (Muñoz et al., 2000; Jordan et al., 2001. Fig. 18a). This episode has been related to plate reorganization in the Southeast Pacific that resulted in a shift from slower, more oblique South AmericaFarallón convergence to more rapid, near-normal South America-Nazca convergence at ca. 28-26 Ma (Muñoz et al., 2000; Jordan et al., 2001). Muñoz et al. (2000) proposed that the change in subduction geometry and the increased trench-normal convergence rate induced a transient period of vigorous asthenospheric-wedge circulation that triggered slab rollback of the subducting Nazca plate, which resulted in regional extension and widespread volcanism. Progressive extension and crustal thinning led to local, continental sedimentation followed by important marine flooding that reached its maximum geographic extension at $\sim 20$ Ma (Encinas et al., 2018). The Pacific transgression covered most of the forearc in the study area and deposited up to $1500 \mathrm{~m}$ of deep-marine sediments. It also reached the present Andean Cordillera between $41^{\circ}$ and $47^{\circ} \mathrm{S}$. Simultaneously, an Atlantic transgression covered most of the foreland in southern Argentina. Paleontologic data suggest a transient connection between the Pacific and Atlantic oceans at $43^{\circ}-44^{\circ} \mathrm{S}$ (Encinas et al., 2018).

An important phase of compressive tectonics that started at $\sim 19 \mathrm{Ma}$ caused the emersion, uplift, and deformation of the Upper Oligocene-Lower Miocene marine strata and older rocks. This phase caused the growth of the Andean Cordillera, and the beginning of foreland sedimentation in south-central Chile and Argentina. (Orts et al., 2012; Rojas Vera et al., 2015; Giambiagi et al., 2016; Horton and Fuentes, 2016; Encinas et al., 2018). Field and seismic information from the forearc area show evidence of tectonic inversion and mild compressional deformation of the Oligocene-Lower.

Miocene strata (Elgueta et al., 2000; Jordan et al., 2001; Melnick and Echtler, 2006; Mella et al., 2012). Most of the forearc became a positive, mountainous area during the late Early-Late Miocene. Syntectonic marine sedimentation took place only in the coastal area and the offshore during this period (Álvarez et al., 2006. Fig. 18b).

After $\mathrm{a} \sim 15$ Myr. hiatus, sedimentation reassumed in the present Central Depression with deposition of the Mininco Formation. This unit is early Pliocene, as indicated by our $\mathrm{U}-\mathrm{Pb}$ dates from tuffs or pumicerich conglomerates (some of them near the basal contact of this unit with basement rocks) that yielded $\sim 5 \mathrm{Ma}$ ages (Table 1, Fig. 10). These dates likely indicate (or approximate) depositional ages since the sampled beds originated from explosive volcanism contemporaneous with sedimentation. Subsequently, coarse-grained fluvial and lahar deposits of the Rodados Multicolores Formation accumulated during the PlioPleistocene. Although $\mathrm{U}-\mathrm{Pb}$ detrital zircons yielded maximum ages between 8.3 and $14 \mathrm{Ma}$, two tuffs from this unit likely indicate depositional ages of 2.7 and 2 Ma (Table 1, Figs. 10, and 11). The Nochaco Formation yielded a maximum $\mathrm{U}-\mathrm{Pb}$ age of $7.5 \mathrm{Ma}$, but the presence of two zircon grains of $3.4 \mathrm{Ma}$ and stratigraphic correlation indicates the likely equivalence of this unit and the Rodados Multicolores Formation. Fluvial sedimentation in the Central Depression finished at $\sim 2 \mathrm{Ma}$ according to our $\mathrm{U}-\mathrm{Pb}$ ages (Table 1 , Figs. 10, and 11), although younger glacial deposits accumulated in the southern part of the study area (Mercer, 1976; Porter, 1981). Correlative units in the coastal area are the lower Pliocene marine strata of the Tubul Formation in the Arauco Peninsula, well-dated with planktonic foraminifera (Rojas, 2000), and the Plio-Pleistocene marine and continental strata of the Cañete Formation (Kaizuka et al., 1973. Fig. 18c). The latter unit also yielded $\mathrm{U}-\mathrm{Pb}$ maximum ages of 8.6 and $11.2 \mathrm{Ma}$, but it overlies the lower Pliocene Tubul Formation, and it is cut by a marine terrace (the Cañete surface) of $\sim 120 \mathrm{ka}$, which constraints its age to the Plio-Pleistocene.

Several data indicate that the uplift of the Coastal Cordillera occurred very recently. A well preserved planar surface in the highest parts of the Coastal Cordillera suggests a recent uplift because the rainy climate of this region is not conducive to its preservation (Figs. 3, 5, 12, 


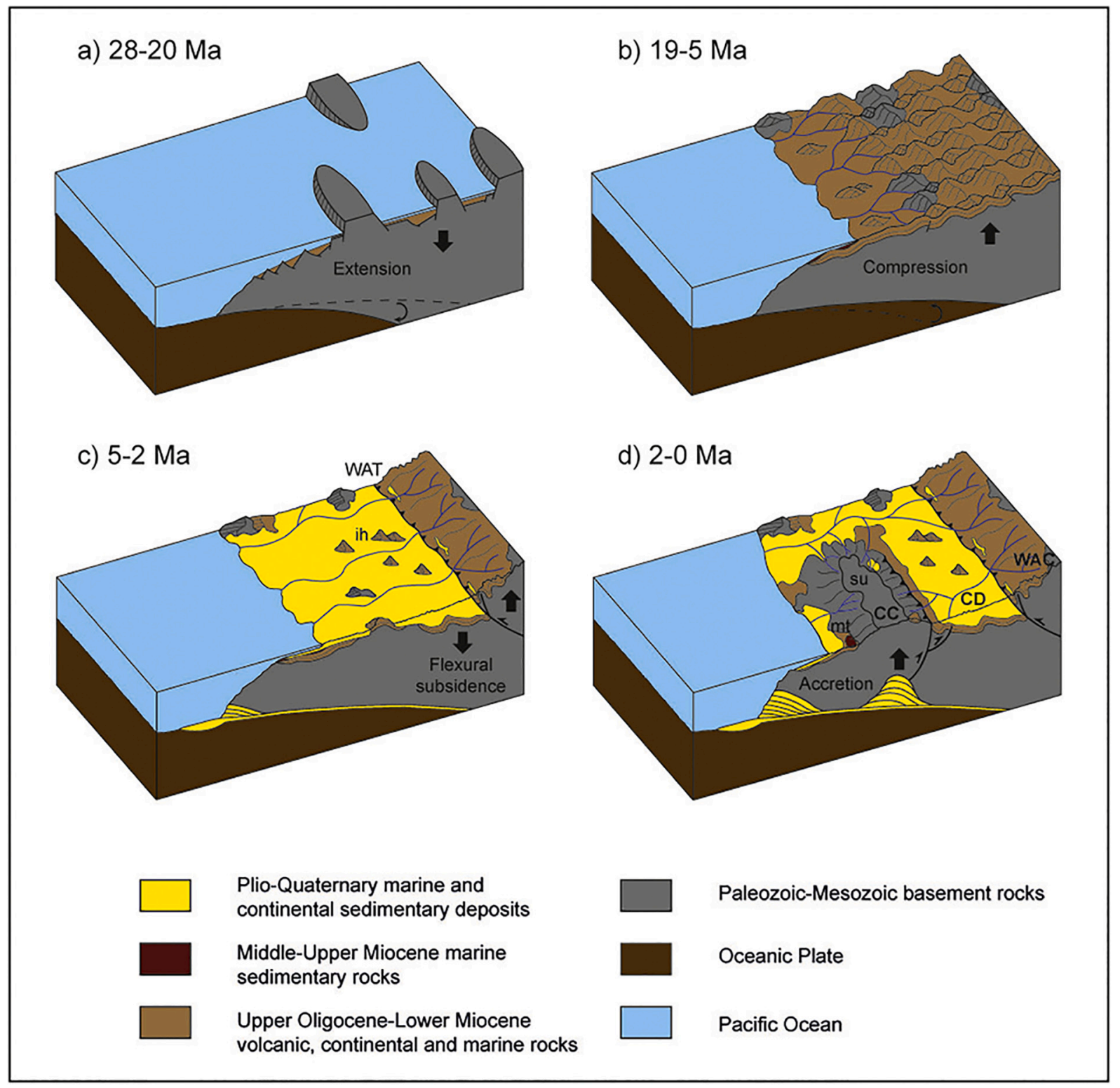

Fig. 18. Schematic block diagrams showing the main phases of the inferred tectono-sedimentary evolution of the forearc of south-central Chile during the late Cenozoic. Large, black arrows show the vertical movements (uplift or subsidence). a) 28-20 Ma. Extensional tectonics led to regional subsidence and sedimentation of volcanic, continental and marine deposits in the forearc and the Andean Cordillera. b) 19-5 Ma. Compressive tectonics caused the deformation and uplift of the Upper Oligocene-Lower Miocene strata and older rocks. Most of the forearc became a mountainous area. Sintectonic sedimentation took place in the coastal area. c) 5-2 Ma. Generation of the West Andean Thrust (WAT) caused significant uplift of the western flank of the Andes, triggering flexural subsidence and the accumulation of coarse-grained deposits in the forearc. ih: isolated hills surrounded by Plio-Pleistocene deposits. d) 2-0 Ma. The increase of sediment flux to the trench caused the growth of the accretionary wedge and the uplift of the Coastal Cordillera (Nahuelbuta and Bueno segments). CC: Coastal Cordillera. CD: Central Depression. WAC: Western Andean Cordillera. su: low-relief uplifted surface. mt: marine terrace. The northern (upper) part of the diagram represents a low-relief area (e.g., the Toltén segment) that was subjected to limited uplift in the last $2 \mathrm{Ma}$.

13, and 14a,b,c,d). Unfortunately, the age of this surface has not been properly constraint, as discussed before. Some authors proposed that the Coastal Cordillera and the Central Depression formed before (e.g., Gana and Wall, 1997) or during the Late Oligocene-Early Miocene (Muñoz et al., 2000), but the occurrence of continental and marine strata of that age at heights up to $\sim 500 \mathrm{~m}$ a.s.l. (Fig. 5; see section 5.1) indicates that the uplift of the Coastal Cordillera postdates their deposition. Based on inverse modeling of apatite fission-track length data, Glodny et al. (2008) detected a Plio-Pleistocene exhumation interval in the Nahuelbuta segment. However, Plio-Pleistocene forearc deposits are the most important markers to constraint the uplift of this range. Outcrops of the Rodados Multicolores Formation occur in the eastern flank of the Bueno segment at heights up to $\sim 620 \mathrm{~m}$ a.s.l. (sample CPEL1; $40^{\circ} \mathrm{S}$ ) whereas equivalent deposits (sample UNI1) crop out in the Central Depression, $25 \mathrm{~km}$ to the SE, at only $33 \mathrm{~m}$ a.s.l. (Figs. 5, and 12). Correlative deposits of the Plio-Pleistocene Cañete Formation in the coastal area are also uplifted since they were deposited near sea-level and, at present, reach heights up to $\sim 200 \mathrm{~m}$ a.s.l. (Fig. 3).

Provenance analysis also accounts for the recent uplift of the Coastal Cordillera. We collected zircon samples from the Mininco, Rodados Multicolores, Nochaco, and Cañete formations (see chapter 3.2). These samples yielded zircon groups with Pleistocene, Pliocene, Miocene, Oligocene, Eocene, Cretaceous, Jurassic, Permian, Carboniferous, Ordovician, and Proterozoic ages (Table 1). Whereas the Coastal Cordillera is primarily composed of Triassic-Paleozoic metamorphic and plutonic rocks, it is evident that the source areas for these units must 
have been located in the Andean Cordillera (Niemeyer and Muñoz, 1983; Suárez and Emparán, 1997; Campos et al., 1998). The only exception is Permian, Paleozoic, or older zircons that could have derived from basement rocks of the Coastal Cordillera or the Central Depression. This notion is in agreement with the abundance of clasts of volcanic composition in the Mininco, Rodados Multicolores, and Cañete formations conglomerates. Interestingly, rivers in the Arauco Peninsula-Tirúa area drain exclusively from the Nahuelbuta mountains (Rehak et al., 2008), mostly composed of metamorphic and plutonic basement rocks and lack volcanic rocks (Figs. 1, and 3). However, the Cañete Formation contains volcanic clasts and detrital zircons derived from the Andean Cordillera, and it is locally overlain by recent fluvial conglomerates composed of metamorphic and plutonic clasts (Fig. 71, and 9). This indicates that during Plio-Pleistocene times rivers born in the Andean Cordillera transected the entire forearc and deposited the equivalent Rodados Multicolores and Cañete formations. In the last $2 \mathrm{Ma}$, the uplift of the Nahuelbuta segment caused the disconnection between the Central Depression and the coastal area, the reorganization of the drainage network, and deposition by locally sourced rivers (Fig. 18d). A similar situation occurred in the Bueno segment, as indicated by the occurrence of an outcrop of the Cañete Formation near Caleta Huellelhue. Rehak et al. (2008) had previously noted a similar change in the provenance of the Pellahuén-Tirúa Rivers, which were split and disconnected from the Andes by Coastal Cordillera uplift. Our data indicate that the reorganization of the drainage network not only affected these rivers but the entire Nahuelbuta and Bueno segments. The occurrence of low-relief entrants, filled with Plio-Pleistocene conglomerates of the Rodados Multicolores Formation, in the limit between the Coastal Cordillera and the Central Depression also evidence the reorganization of the drainage network by tectonic uplift. It is unlikely that the paleo-rivers that deposited these Andean-derived conglomerates had ended in "blind" valleys (Fig. 3). This is particularly notorious in the Purén basin, where reverse faults uplifted the high-relief areas bordering this depressed area, where Oligo-Miocene and Plio-Pleistocene deposits have been preserved from erosion (Fig. 3). Finally, the occurrence of uplifted and folded marine terraces in the Arauco-Nahuelbuta area, the Cañete, Esperanza, and Nochas surfaces (Fig. 3, and 14a), reaching maximum elevations of 232, 360, and $471 \mathrm{~m}$ a.s.l. and ages of ca. 130-116, 220-200, 340-320 ka respectively (Kaizuka et al., 1973; Melnick et al., 2009), also account for the recent uplift of this area.

The cited data indicate that the uplift of the Coastal Cordillera occurred after the deposition of the Rodados Multicolores and the correlative Cañete Formation (i.e., after $\sim 2$ Ma. Fig. 18d). The most robust evidence comes from the presence of an outcrop of the Rodados Multicolores Formation at $\sim 620 \mathrm{~m}$ a.s.l. in the Bueno segment (sample CPEL1. Figs. 5, and 12). The occurrence of another outcrop of the same unit at only $33 \mathrm{~m}$ a.s.l. (sample UNI1) indicates an uplift of $\sim 600 \mathrm{~m}$. Thus, an uplift rate of $\sim 0.3 \mathrm{~mm} / \mathrm{yr}$. for this area is estimated. This is a minimum estimation because the Rodados Multicolores Formation could have also covered more elevated parts of the Bueno segment, but this unit was extensively eroded after the uplift of the Coastal Cordillera. Another uplift estimation of $3112 \mathrm{~m}$ comes from the Camarones fault (see section 5.1) (Figs. 5, 13, 15, and 16), indicating a higher uplift rate of $1.6 \mathrm{~mm} / \mathrm{yr}$. Melnick et al. (2009) measured the elevation of 96 shoreline angles from the Cañete, Esperanza, and Nochas surfaces in the Nahuelbuta segment and calculated similar uplift rates between 1.8 and $0.36 \mathrm{~mm} / \mathrm{a}$.

\subsection{Implications on the evolution of the West Andean Thrust}

We have noted the existing debate in the kinematics, style of deformation, and tectonic drivers of the Andes of central Chile and Argentina (see chapter 2.1.2). Most studies propose that shortening in the Andean Cordillera is associated with an eastward propagation of deformation into the foreland (e.g., Mpodozis and Ramos, 1989; Charrier et al., 2007; Farías et al., 2010; Giambiagi et al., 2014). Conversely, Armijo et al.
(2010) proposed that Andean deformation progressively shifted westward during the last $\sim 25-22 \mathrm{Ma}$. We believe that our studies on the tectono-sedimentary evolution of the forearc of south-central Chile can help to resolve this dispute. As indicated before, an important phase of extensional tectonics caused the deposition of volcanic and sedimentary rocks during the Oligocene-Early Miocene (e.g., Muñoz et al., 2000; Jordan et al., 2001; Encinas et al., 2018. Fig. 18a). Notably, this event was not limited to the forearc since coeval volcanic and marine rocks extend between the Pacific and Atlantic coasts in some areas (Jordan et al., 2001; Encinas et al., 2018 and references therein). The occurrence of Upper Oligocene-Lower Miocene marine rocks in the Andean Cordillera of south-central Chile and Argentina indicates that uplift of this range had necessarily to start after the marine transgression (Encinas et al., 2018). Accordingly, several studies indicate that synorogenic deposition in the foreland started at $\sim 19$ Ma (Orts et al., 2012; Rojas Vera et al., 2015; Giambiagi et al., 2016; Horton and Fuentes 2016; Encinas et al., 2018). Oligocene-Lower Miocene strata in the forearc also show evidence of tectonic inversion and compressional deformation that took place within the late Early-Late Miocene interval as discussed before (Elgueta et al., 2000; Jordan et al., 2001; Álvarez et al., 2006; Melnick and Echtler, 2006; Mella et al., 2012. Fig. 18b). Most of the forearc became a positive, mountainous area as indicated by seismic, borehole, and gravimetric data that show an irregular paleorelief carved on Oligo-Miocene and older rocks (e.g., García, 1968; Rubio, 1990; Elgueta et al., 2000; Yáñez et al., 2015; González et al., 2018). The difference in elevation between the lowest and the highest parts of this paleorelief is approximately $1000 \mathrm{~m}$ (see González et al., 2018). Sedimentation resumed in the forearc during the lower Pliocene (Fig. 18c). These data indicate that the forearc did not act as a western foreland basin during the last $25 \mathrm{Ma}$ as proposed by Armijo et al. (2010). Instead, it was subjected to extension during the Lower Oligocene-Early Miocene and compressive deformation and uplift during the late Early-Late Miocene. Sedimentation in this area took place again in the last $5 \mathrm{Ma}$.

The cause of the last sedimentary cycle in the forearc deserves further consideration. After a hiatus of $\sim 15 \mathrm{Ma}$ (except in the coastal area. Fig. 6), sedimentation resumed $\sim 5 \mathrm{Ma}$ ago with deposition of the continental Mininco Formation in the present Central Depression and the marine Tubul Formation in the Arauco Peninsula. It followed the deposition of the coarse-grained fluvial and lahar deposits of the Rodados Multicolores Formation in the present Central Depression and the coeval marine and fluvial deposits of the Cañete Formation in the coastal area. Stiefel (1968) noted that the Rodados Multicolores Formation was erroneously interpreted as glacial deposits by Brüggen (1950), who confused lahar deposits with tillites. Similarly, Hauser (1986) noted that Porter (1981) misinterpreted outcrops of the Rodados Multicolores Formation between $41^{\circ}$ and $42^{\circ} \mathrm{S}$ as glacial deposits based on their intense weathering.

The deposition of the cited correlative Plio-Pleistocene units was continuous across the entire forearc and predated the uplift of the Coastal Cordillera, as discussed above. Equivalent deposits in Central Chile $\left(34^{\circ} \mathrm{S}\right)$ also extend between the western flank of the Andean Cordillera and the coastal area (Brüggen, 1950; Cuadra, 1986; Encinas et al., 2006). The coarsening-upward trend of the cited Plio-Pleistocene deposits and the large size of the Rodados Multicolores conglomerates suggest progressive uplift and erosion of the western flank of the Andean Cordillera as previously proposed by Hauser (1986) and Maksaev et al. (2009). We do not discard the influence of climate, but the fact that the area located between $33^{\circ}$ and $42^{\circ} \mathrm{S}$ presents huge differences in mean temperature and precipitation, and it was subjected to a similar tectonosedimentary evolution during the Plio-Pleistocene indicates that tectonics had to be the primary cause. Accordingly, thermocronological data indicate major uplift and exhumation of the western Andean Cordillera of central and south-central Chile during the Late MiocenePliocene (Thomson, 2002; Adriasola et al., 2006; Glodny et al., 2008; Spikings et al., 2008; Maksaev et al., 2009; Thomson et al., 2010) (see chapter 2.1.2). These authors studied different segments of the Andes 
and attributed exhumation during this period to diverse causes, including the subduction of the Juan Fernández Ridge (Spikings et al., 2008; Maksaev et al., 2009), transpression associated with the activity of the LOFZ (Thomson, 2002; Adriasola et al., 2006), or glacial erosion in Patagonia. Although we do not discard the local influence of the aforementioned factors, neither of them accounts for Late MiocenePliocene exhumation in the entire Andes between $33^{\circ}$ and $42^{\circ} \mathrm{S}$. Farías et al. (2008a) also demonstrated the recent uplift of the western slope of the Andean Cordillera in central Chile after their determination of significant river incision in the last $5 \mathrm{Ma}$ with the help of well-dated igneous rock markers. The occurrence of Upper Miocene and Pliocene plutonic rocks in the southern part of our study area at $42^{\circ} \mathrm{S}$ (Duhart, 2008) also accounts for the late Miocene-Pliocene uplift of the western Andes. The occurrence of uplifted outcrops of Plio-Pleistocene deposits in the western flank of the Andes of central and south-central Chile (Ferraris, 1981; Cuadra, 1986; Armijo et al., 2010) evidence the progressive advance of the mountain front towards the west.

Plio-Pleistocene deposits in the forearc have highly variable thicknesses that reach more than $2000 \mathrm{~m}$. Thus, the accommodation space cannot have been created by a global sea-level rise and the consequent fluvial sedimentation to maintain river equilibrium profile since maximum eustatic sea-level changes during the last $5 \mathrm{Ma}$ are just on the order of $100 \mathrm{~m}$ (Haq et al., 1987). In addition, González et al. (2018) noted that the lowest part of the paleorelief carved in Oligo-Miocene or older rocks in central Chile is located at elevations of $200 \mathrm{~m}$ below the present sea level, which indicates that the Central Depression has been subjected to subsidence. Information from ENAP wells in the Central Depression between $\sim 41^{\circ}$ and $42^{\circ} \mathrm{S}$ show that the thickness of PlioPleistocene deposits increases considerably to the east and reaches $\sim 2250$ m near the limit with the Andean Cordillera (Fig. 17). In addition, the grain size of these deposits grows progressively from the coastal area to the Andean Cordillera (see section 3.5). The cited sedimentologic characteristics of Plio-Pleistocene deposits, the occurrence of a major thrust in the limit between the Central Depression and the Andes, and geological evidence indicating important uplift of the western flank of this range during the late Miocene-Pliocene, strongly suggest that the accommodation space for Plio-Pleistocene deposition was principally generated by flexural subsidence.

We consider that the cited pieces of evidence solve the dispute on the kinematics of the Andes during the Neogene and help to understand the geologic evolution of the western flank of this chain during that period. Several studies show that the Andes of central and south-central Chile grew principally eastward since $\sim 20$ Ma (e.g., Jordan et al., 1983; Mpodozis and Ramos, 1989; Astini and Dávila, 2010; Giambiagi et al., 2014). The Central Depression, which has been classically considered to act as a forearc basin during the entire Neogene (e.g., Jordan et al., 1983; Horton, 2018), was, in turn, deformed and uplifted during the Middle-Late Miocene, a notion that should be taken into account to understand the kinematics, polarity, and evolution of the Andean Cordillera of south-central Chile. A major west vergent back-thrust formed in the limit between the Andes and the forearc, causing a vertical throw $>2000 \mathrm{~m}$. Uplift of the western flank of the Andean Cordillera caused flexural subsidence in the forearc that acted as a foreland basin, but only during the last $5 \mathrm{Ma}$ and not throughout the entire Neogene as proposed by Armijo et al. (2010).

\subsection{Coastal Cordillera uplift mechanisms}

The previous analysis indicates three fundamental processes in the morphostructural configuration of the forearc of south-central Chile during the Cenozoic. 1) Inversion of the Upper Oligocene-Lower Miocene extensional basins and development of an uplifted area in the forearc during the late Early-Late Miocene. 2) Generation of an important back-thrust in the limit between the Andes and the forearc, major uplift of the western Andean Cordillera, flexural subsidence in the forearc, and accumulation of Plio-Pleistocene deposits. 3) Uplift of some areas of the Coastal Cordillera (the Nahuelbuta and Bueno segments) in the last $2 \mathrm{Ma}$ (Fig. 18).

Other authors have proposed different explanations. One of the most popular is that of Brüggen (1950), who postulated that the entire margin (i.e., the forearc and the Andean Cordillera) was uplifted during the Tertiary and that extensional tectonics caused the subsequent downwarping of the Central Depression, which formed a large graben between the Coastal and Andean Cordilleras, during the Pleistocene (Fig. 19a, and b). Muñoz et al. (2000) also proposed that the Central Depression was formed by extensional tectonics, but they considered that this event started in the Late Oligocene-Early Miocene. However, geologic evidence discussed above indicates the recent ( $<2 \mathrm{Ma}$ ) uplift of the Coastal Cordillera and the occurrence of reverse faults in the western and eastern limits of the Central Depression (McDonough et al., 1997; Sernageomin, 1998; Melnick et al., 2009; Encinas et al., 2013; Sepúlveda et al., 2019). Farías et al. (2006; 2008a) also proposed the uplift of the entire margin during the Late Miocene, but they considered instead that the Central Depression formed by differential fluvial erosion that was more intense in this area than in the Coastal and Andean cordilleras (Fig. 19c, and d). They also proposed that sedimentation of PlioPleistocene fluvial deposits was caused by the uplift of the western Coastal Cordillera, which partially blocked the river drainage inducing sedimentation in the Central Depression. Our data indicate instead that the uplift of the Coastal Cordillera postdates the accumulation of PlioPleistocene deposits that originally extended between the Andes and the coastal area. In addition, the occurrence of reverse faults in the western and eastern limits of the Central Depression indicates tectonic processes in the origin of this morphostructural unit. Armijo et al. (2010) proposed that orogenic loading caused by the trenchward (westward) growth of the Andes since $\sim 25-22$ Ma generated a foreland basin, the Central Depression, and a fore-bulge, the Coastal Cordillera (Fig. 19e). As discussed before, we believe that the forearc was subjected to flexural subsidence only during the Plio-Pleistocene and that the uplift of the Coastal Cordillera occurred in the last $\sim 2$ Ma. Giambiagi et al. (2014) proposed that the widening of the crustal root caused by Andean shortening triggered passive surface uplift in the Coastal Cordillera by isostatic rebound. Uplift occurred first in the eastern part of this range at $18 \mathrm{Ma}$ and then in its western flank at the beginning of the Pliocene (Giambiagi et al., 2014). Our studies also contradict this model. Finally, Melnick et al. (2009) proposed that the uplift of the Nahuelbuta segment started in the early Pliocene, being simultaneous with the deposition of the Tubul Formation. However, we have shown that the Coastal Cordillera uplift started after the deposition of this unit and the overlying Cañete Formation.

Chen et al. (2017) carried out dynamic analogue models of timeevolving subduction in threedimensional space. Their experiments show the generation of an area of forearc dynamic subsidence on the overriding plate and a local topographic high between this area and the trench. Chen et al. (2017) observed that the horizontal position of the maximum depression corresponds with that of the deepest contact point between the subducting and overriding plates at the subduction zone interface. They analyzed the forces acting on the forearc lithosphere and compared their model results with previous investigations of overriding plate topography using geodynamic models (e.g., Hassani et al., 1997; Guillaume et al., 2010; Yang et al., 2016). Chen et al. (2017) proposed that there are three potential candidates to explain forearc subsidence: the shear force at the subduction zone interface, the viscous drag force induced by the vertical movement of the mantle flow in the mantle wedge region, and the trench suction force, which is normal to the subduction zone interface. They concluded that trench suction is the most important force, whereas shear and drag forces play only a minor role in driving forearc subsidence. However, Chen et al. (2017) noted that trench suction force is only relevant when slab rollback causes the progressive increase of the slab dip angle. In contrast, when the slab maintains a relatively constant angle with time, topographic subsidence is nearly the same along the subduction zone interface. Chen et al. 

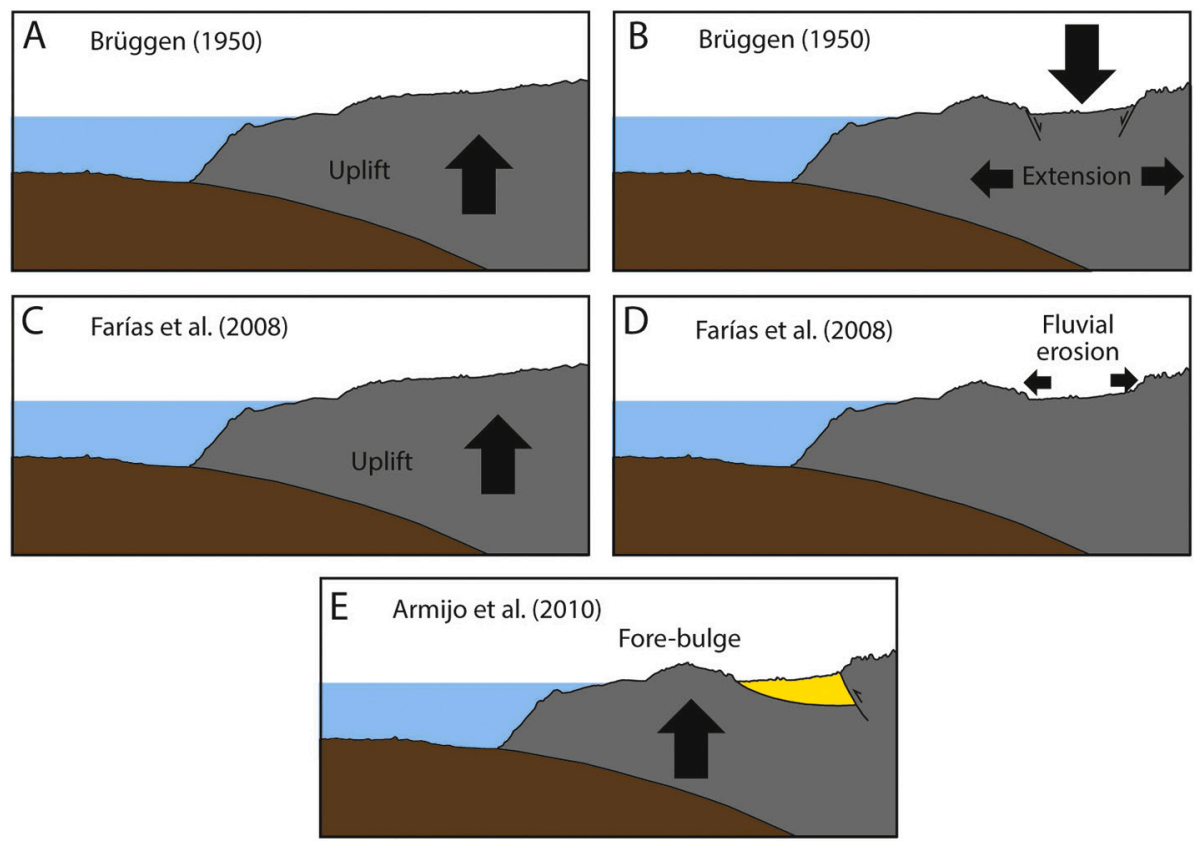

Fig. 19. Most popular models for the genesis of the Coastal Cordillera and the Central Depression. Brüggen (1950) model: A) Uplift of the entire margin during the Tertiary, and B) downwarping of the Central Depression by extensional tectonics during the Pleistocene. Farías et al. (2006; 2008a) model: C) Uplift of the entire margin during the Late Miocene, and D) formation of the Central Depression by differential fluvial erosion. Armijo et al. (2010) model: E) Orogenic loading caused by the trenchward growth of the Andes since $\sim 25$ Ma generated a foreland basin, the Central Depression, and a forebulge, the Coastal Cordillera.
(2017) model could account for the tectonic origin of the Central Depression of south-central Chile. However, Muñoz et al. (2000) proposed that slab rollback caused the transient steepening of the subducting Nazca plate during the late Oligocene-early Miocene and that the slab angle decreased again to its present position during the middlelate Miocene. Our studies show that the Coastal Cordillera and Central Depression formed during the Plio-Quaternary. Since there is no evidence to indicate any change in the slab angle nor other significant modifications in subduction geodynamics during that period, we consider that trench suction is an unlikely explanation to account for Central Depression subsidence.

As noted before, most authors have interpreted Coastal ranges as forearc highs related to accretionary processes (e.g., Brandon et al., 1998; Clift and Vannucchi, 2004). Lohrmann et al. (2006), Rehak et al. (2008), and Melnick et al. (2009) attribute this origin to the Coastal Cordillera in south-central Chile. In accretionary margins, trench sediment accumulates by frontal accretion and underplating, forming a wedge-shaped body that grows with time (Cloos and Shreve, 1988; Von Huene and Scholl, 1991; Brandon et al., 1998; Clift and Vannucchi, 2004; Maksymowicz, 2015). The backstop is the boundary between the accreted sediments and the more rigid continental basement that works as an indenter (Cloos and Shreve, 1988). In theory, underplating causes uplift without additional shortening (Cloos and Shreve, 1988). However, the Coastal Cordillera of south-central Chile shows evidence of compressive deformation that affects basement rocks, leading to a crustal-scale buckling. Brandon (2004) observed similar characteristics in the Cascadia margin and proposed a model to explain the evolution of Coast Ranges that accounts for the deformation of basement rocks. In this model, deformation is driven by the motion of a subducting proplate and an overriding retro-plate. These plates correspond to the relatively strong lithospheric mantle and are rigid, whereas the overlying crust deforms to accommodate subduction. This leads to the formation of a double-side "subduction wedge" (Brandon, 2004). This is composed of an "accretionary complex", formed by accreted sediments, and a "structural lid" formed by rocks of the overriding plate. As the accretionary complex grows, the structural lid is deformed and driven to the rear of the wedge, creating a large backfold and a west-dipping retroshear zone. The model of Brandon (2004) has been proposed for the origin of the Coastal Cordillera in north-central Chile $\left(\sim 31^{\circ} \mathrm{S}\right)$ by Comte et al. (2019) and can also be applied to the Nahuelbuta and Bueno segments in south-central Chile (Fig. 18d). In these areas, a relatively narrow accretionary prism composed of deformed sediment abuts the continental basement. To the east, the cited segments have an asymmetrical dome-like morphology that constitutes the forearc high (i.e., the Coastal Cordillera) of the subduction wedge and is composed principally of upper Paleozoic-Triassic metamorphic and plutonic rocks. These rocks form the structural lid of the subduction wedge. The Camarones reverse fault marks the eastern limit of the subduction wedge and forms the west-dipping retro-shear zone of Brandon (2004) model.

A fundamental question is why the Coastal Cordillera of southcentral Chile was uplifted in the last $2 \mathrm{Ma}$ and not before. Seismic data indicate that the margin of south-central Chile is characterized by a $\sim 2 \mathrm{~km}$ thick trench fill and a relatively narrow accretionary prism (5-40 km wide) that abuts the truncated continental basement (Bangs and Cande, 1997; Contreras-Reyes et al., 2008, 2010). These authors signaled that the relatively small size of this wedge is not consistent with a long history of accretion and calculated that it formed in the last $\sim 1-2$ million years. This implies previous episodes of nonaccretion or tectonic erosion (Bangs and Cande, 1997; Contreras-Reyes et al., 2010). The change from subduction erosion to accretion in convergent margins is principally related to exceeding a critical trench-fill thickness of $\sim 1 \mathrm{~km}$, which surpasses the transport capacity of subduction channels and lead to their obduction (e.g., Von Huene and Scholl, 1991; Clift and Vannucchi, 2004; Kukowski and Oncken, 2006). Thus, nonaccretion or subduction erosion in the margin of south-central Chile could have occurred when the trench fill was insufficient to completely cover the relief of the subducting crust (Bangs and Cande, 1997). The margin probably changed to accretionary by an increase in sediment flux to the trench in the last $\sim 2 \mathrm{Ma}$ (Bangs and Cande, 1997. Fig. 18d).

Melnick and Echtler (2006) proposed that the increase of trench sedimentation was caused by the combination of glacial denudation and Andean uplift. Although we do not discard that climate has played a role in the increase of trench sedimentation during the Plio-Pleistocene, we consider that this is not the principal cause because Coastal Cordillera uplift appears to have been coeval in a large region with significant climatic differences. Glaciation seems to have been relevant only in the southern part of the study area (Mercer, 1976; Porter, 1981; Rabassa, 2008). In addition, glacial periods are characterized by a drop in global sea-level, and sedimentation of Plio-Pleistocene deposits of the Cañete Formation and equivalent units in the coastal area started with the 
accumulation of transgressive marine sediments. Regarding Andean uplift, this has taken place during the last $\sim 20 \mathrm{Ma}$ (e.g., Astini and Dávila, 2010; Orts et al., 2012; Giambiagi et al., 2016) and yet the uplift of the Coastal Cordillera is constrained to the last $2 \mathrm{Ma}$. In our opinion, the fundamental change that caused a significant increase in sediment flux to the trench was the generation of the West Andean Thrust (sensu Armijo et al., 2010. Fig. 18c, and d). This major west vergent fault formed probably in the late Miocene-early Pliocene, as discussed before, and caused the progressive uplift of the western flank of the Andes, causing important topographic differences with the forearc. Progressive uplift significantly enhanced erosion rates in the western Andes and caused deposition of coarse-grained deposits across the entire forearc. Much of the eroded sediment was likely transported seaward, moved downslope, and accumulated progressively in the trench until the critical fill thickness of $\sim 1 \mathrm{~km}$ was completed. The high amount of sediment exceeded the transport capacity of the subduction channel and caused the change from non-accretion or subduction erosion to accretion. Progressive growth of the accretionary complex caused deformation of the structural lid that was folded and uplifted, giving birth to a forearc high, the Coastal Cordillera (Fig. 18d).

\subsection{Latitudinal changes}

The forearc of south-central Chile presents significant morphotectonic differences (see sections 2.1.1 and 3.3). The Coastal Cordillera has two high-relief areas, the Nahuelbuta and Bueno segments, characterized by their recent $(<2 \mathrm{Ma})$ uplift, asymmetrical dome-like morphology, and highly dynamic fluvial systems (Rehak et al., 2008. Figs. 1, 3, and 5). Conversely, the low-relief Toltén segment lacks significant topographic contrasts, active river incisions, or recent drainage modifications suggesting geomorphic stability (Rehak et al., 2008. Figs. 1, and 4). Another low-elevation area, a marine strait between continental Chile and the Chiloé Island (the Canal de Chacao), is located south of the Bueno segment (Fig. 5). The Central Depression generally has a flat morphology, but it also presents some elevated areas. Morphotectonic segmentation is not exclusive of our study area but also characterizes other parts of the Chilean forearc (e.g., Brüggen, 1950; Farías et al., 2008).

Plio-Pleistocene deposits are a key marker to determine differential uplift in the forearc. The lower member of the Cañete Formation consists of marine deposits that are transitionally covered by fluvial deposits of the upper member (Fig. 7g, and 9). The cited members are both correlatives with continental deposits of the Rodados Multicolores Formation (Fig. 6). The deposition of these units was caused by paleo-fluvial systems born in the Andean Cordillera that traversed distances of only $100-150 \mathrm{~km}$ and flowed into the Pacific (Fig. 18c). According to the thalweg elevation of current rivers traversing the forearc, PlioPleistocene rivers height must have varied roughly between $0 \mathrm{~m}$ a.s.l. in the river mouth and $\sim 100 \mathrm{~m}$ a.s.l. in the limit of the forearc with the Andean Cordillera. Thus, Plio-Pleistocene deposits provide a relatively good constraint to calculate differences in tectonic uplift.

The two high-relief areas in the Coastal Cordillera were uplifted in the last $2 \mathrm{Ma}$, as indicated by the occurrence of outcrops of the Rodados Multicolores Formation at heights up to $\sim 620 \mathrm{~m}$ a.s.l. in the Bueno segment, and by the disconnection between the Cañete and Rodados Multicolores formations after the raising of the Nahuelbuta and Bueno segments (see sections 5.1, and 6.1). The uplift of the Loncoche ridge took place in the same period, as indicated by the presence of PlioPleistocene deposits at heights up to $\sim 500 \mathrm{~m}$ a.s.l. In contrast, the relief of the low-elevation segments in the Coastal Cordillera and most of the Central Depression was principally achieved by the combination of the late Early-Late Miocene compressional stage and the subsequent deposition of Plio-Pleistocene sediments. These areas were subjected to minor uplift in the last $2 \mathrm{Ma}$ since Plio-Pleistocene deposits occur at maximum heights of $\sim 200 \mathrm{~m}$.

What is the cause of morphotectonic segmentation in the forearc?
This question has not an easy answer. Factors controlling the tectonic segmentation in the forearc are related to different causes, including the characteristics of the incoming Nazca plate (age, discontinuities, subduction velocity, or slab dip); the nature and amount of trench sediment; and fore-arc rheology among other factors (Hackney et al., 2006; Moreno et al., 2018; references therein).

Melnick et al. (2009) discussed localized underplating of subducted trench sediment as a possible cause to explain the anomalous uplift of the Arauco-Nahuelbuta region. They discarded this mechanism because they argued that there is not a clear correlation between the location of large submarine fans and areas with higher coastal uplift. However, Thornburg et al. (1990) noted that part of the sediment deposited between the southern part of the study area $\left(\sim 41^{\circ} S\right)$ and the Juan Fernández Ridge $\left(\sim 33^{\circ} \mathrm{S}\right)$ is redistributed within the trench, from south to north, following the axial gravitational gradient and being dammed by the cited aseismic ridge. Thus, higher amounts of sediment locally deposited in the trench by large submarine fans probably do not imply a significant difference in the quantity of material accreted in those areas.

Melnick et al. (2009) proposed that the anomalous uplift of the Nahuelbuta segment could be related to the strike-slip Liquiñe Ofqui Fault Zone (LOFZ). They suggested that this could be caused by the northward translation of the fore-arc sliver along this fault system and its collision against a buttress. According to these authors, deformation in this area is related to contractional and transpressional structures that strike oblique to the margin. However, clear structural evidence indicating the proposed northward collision against a buttress is lacking. According to regional geological maps, the cited faults do not appear to displace Cenozoic strata (Sernagemin, 2003). We consider that a clear relation between the uplift of the Nahuelbuta segment and the LOFZ is not evident. In addition, this cause does not explain the uplift of the Bueno segment.

Brandon et al. (1998) and Brandon (2004) noted that the Olympic Mountains in the Coastal Range of the Cascadia margin have been subjected to more significant uplift and deeper exhumation than other segments of this margin. They proposed that this is related to the shallower dip of the subducting slab in this area. Slab depth controls the amount of material that can be accreted (Brandon et al., 1998). Because the wedge beneath the Olympics is smaller than elsewhere along the margin, less time was needed for the forearc high to become emergent (Brandon et al., 1998; Brandon, 2004). Although some authors have reported small lateral variations of the slab dip in the Nahuelbuta and Tolten segments (e.g., Hackney et al., 2006; Tašárová, 2007), seismological studies show that the subducting slab across south-central Chile $\left(35^{\circ}-43^{\circ} \mathrm{S}\right)$ has a similar angle of $\sim 30-33^{\circ}$ near the down-dip limit of the seismogenic zone ( $\leq 45 \mathrm{~km}$ depth) (Lange et al., 2007; and references therein).

Several authors have discussed the role of subducting oceanic fracture zones in forearc segmentation (e.g., Rehak et al., 2008; Moreno et al., 2014; Basset and Watts, 2015). In our study area, there are three subducting fracture zones (FZ), the Mocha, Valdivia, and Chiloé FZ (Figs. 1, and 20). Some authors have proposed that the Mocha Fracture Zone caused the anomalous rapid emergence of the Nahuelbuta segment during the Quaternary (e.g., Lohrmann et al., 2006). However, this fracture zone is currently subducting in the northern limit of the Nahuelbuta mountains and cannot explain the uplift of this range (Fig. 20). In addition, the Mocha FZ subducts obliquely to the convergence vector and the trench axis, migrating southward at $3.1 \mathrm{~cm} / \mathrm{a}$ (Contreras-Reyes et al., 2008), which makes its impact timetransgressive (Rehak et al., 2008). Conversely, there is an excellent correlation between the subduction of oceanic fracture zones and lowelevation segments of the Coastal Cordillera, as depicted in Fig. 20. In particular, the Chiloe FZ coincides with a marine strait between continental Chile and Chiloé Island. To the south, the Guafo FZ also coincides with another marine strait between Chiloé and the Guaitecas islands (Fig. 20). Oceanic fracture zones are sinks for $\mathrm{H}_{2} \mathrm{O}$ due to the low temperature $\left(<200{ }^{\circ} \mathrm{C}\right)$ hydrothermal seawater alteration of the oceanic 

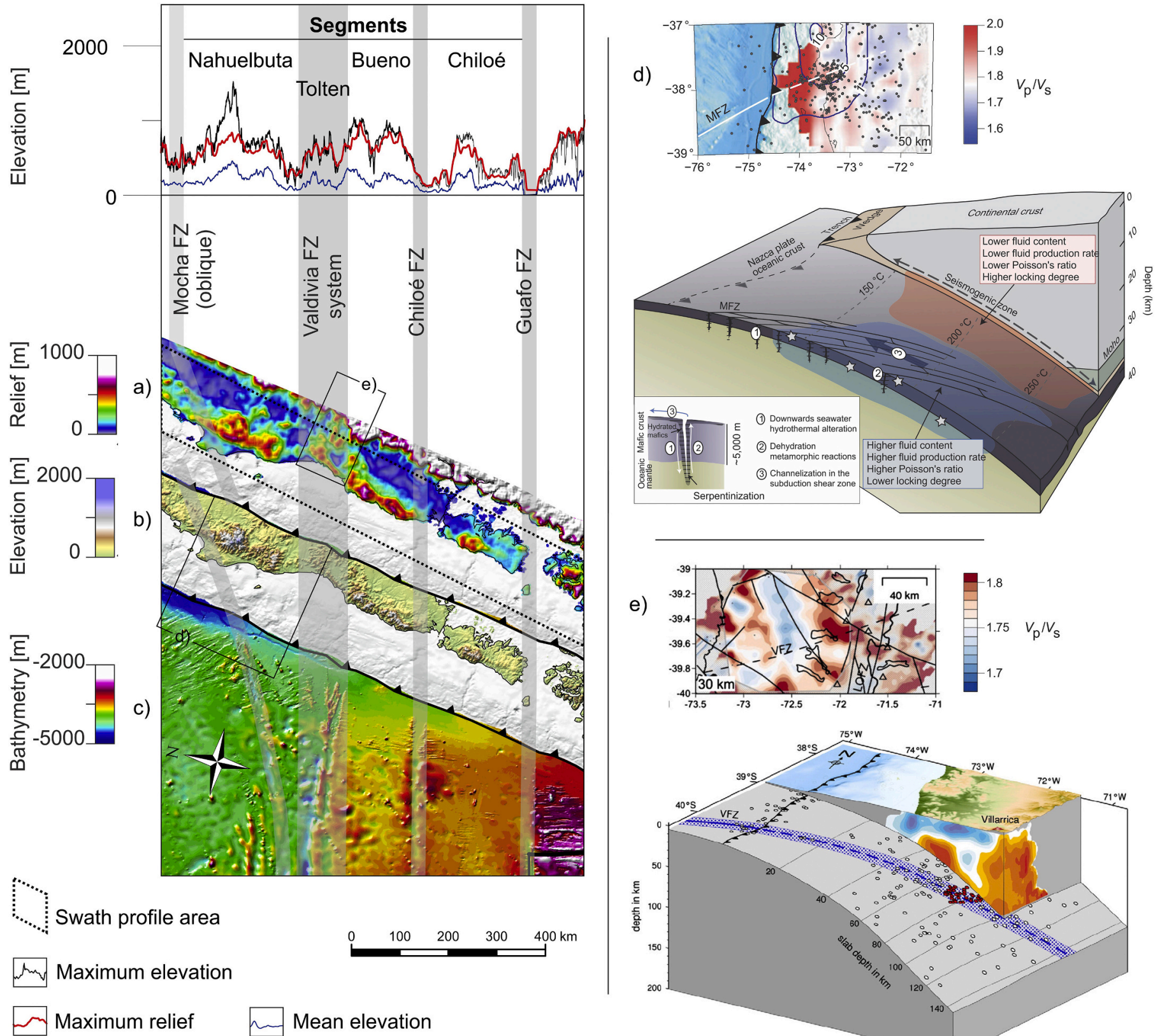

e)
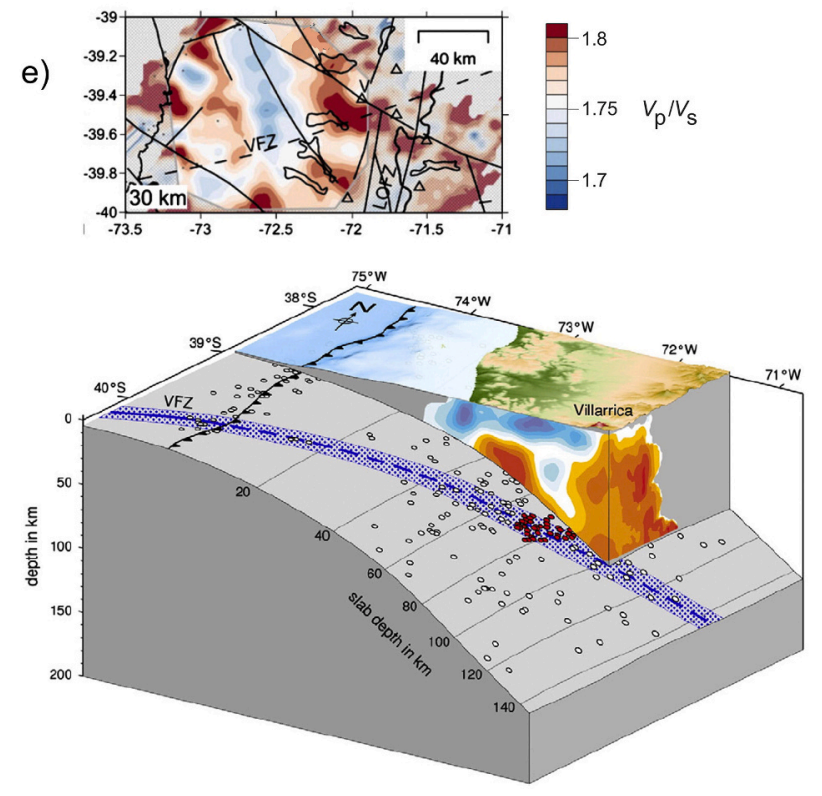

Fig. 20. Digital elevation model analysis of the Coastal Cordillera and the Nazca plate. Above: Swath profiles projections perpendicular to the trace of main fracture zones of the maximum elevation (black curve), maximum relief (red curve), and mean elevation (blue curve) profiles. Below: a) map of the computed relief within a $2.5 \mathrm{~km}$ radius; b) topographic map of the Coastal Cordillera; c) Nazca Plate bathymetry. d) Vp/Vs ratios near the Mocha FZ along the top of the oceanic plate, 2010 Maule earthquake $8.8 \mathrm{Mw}$ rupture zone (blue contours), seismicity (black dots) and a conceptual view taken from Moreno et al. (2014); e) Vp/Vs ratios near the Valdivia FZ system at $30 \mathrm{~km}$ depth and a conceptual view taken from Dzierma et al. (2012). FZ: Fractures zones. (For interpretation of the references to colour in this figure legend, the reader is referred to the web version of this article.)

crust and the uppermost part of the oceanic mantle (Moreno et al., 2014). Tomographic surveys show decreasing seismic velocities along the length of the subduction-zone interface in south-central Chile, corroborating the hydration associated with oceanic fractures (Contreras-Reyes et al., 2008; Dzierma et al., 2012; Moreno et al., 2014). Dehydration of fractures during subduction causes enhanced fluid transport into the system (Moreno et al., 2014). Fluid affects the effective basal friction coefficient of the accretionary wedge, reducing its internal deformation, which inhibits forearc uplift in these areas (Maksymowicz, 2015). Based on geodetic and seismological data, Moreno et al. (2014) noted that elevated pore-fluid pressure zones characteristic of oceanic fractures correlate spatially with parts of the plate interface that are poorly locked and slip aseismically. In contrast, lower pore-fluid pressure zones correlate with locked parts where unstable slip and earthquakes occur, such as the Arauco-Nahuelbuta area (Moreno et al., 2011, 2014). Whereas weak locking areas coincide with low-elevation forearc segments in south-central Chile, there is a good correlation between subduction of oceanic fracture zones, earthquake dynamics, and long-term forearc deformation as noted by Moreno et al. (2011).

The Central Depression also shows topographic variations. Isolated hills of Oligo-Miocene and older rocks correspond to the highest peaks of a middle-late Miocene paleo-relief that were not covered by the subsequent deposition of Plio-Pleistocene fluvial sediments (Fig. 3). However, 
the most important and puzzling morphostructural feature is the Loncoche ridge, $\mathrm{a} \sim \mathrm{NE}-\mathrm{SW}$ trending mountainous area that transects the Central Depression and presents altitudes up to $\sim 800 \mathrm{~m}$ a.s.l. (see section 5.2. Figs. 1, and 4). This ridge is mostly composed of PaleozoicTriassic metamorphic rocks and secondarily by Oligo-Miocene sedimentary rocks (Duhart et al., 2003; Quiroz et al., 2007). Thomson et al. (2010) obtained a (U-Th)/He age of $8.82 \pm 0.53$ Ma that could indicate late Miocene exhumation of this ridge, but a single age is statistically unreliable. There are several small outcrops of Plio-Pleistocene conglomeratic fluvial deposits of the Nochaco Formation that reach maximum elevations of $\sim 500 \mathrm{~m}$ a.s.l. (present river thalwegs in this area reach only $\sim 50-80 \mathrm{~m}$ a.s.1.). The conglomerates typically mantle elevated planar surfaces that abut against higher hills made of metamorphic rocks (Fig. 14 e, and f). This indicates that Plio-Pleistocene fluvial deposits were originally deposited in the lower parts of a paleorelief carved on Paleozoic and Oligo-Miocene rocks and that the Loncoche ridge area was uplifted afterward.

The genesis of the Loncoche ridge is uncertain. Farías et al. (2008a, b) proposed that junction ridges between the Coastal and the Andean cordilleras are the relicts of a previously uplifted area that resisted erosion because they are composed of comparatively harder lithologies. However, we have shown that the uplift of the Loncoche ridge occurred in the last $2 \mathrm{Ma}$ after the deformation and erosion of Paleozoic and Oligo-Miocene rocks during the middle-late Miocene and the subsequent accumulation of fluvial deposits during the Plio-Pleistocene. Lavenú and Cembrano (1999) interpreted that the Loncoche ridge is delimited by faults with a NE-SW trend. Conversely, Quiroz et al. (2007) proposed that these limit faults are oriented NW-SE based on the interpretation of satellite images and aerial photographs. On the basis of seismic studies, Dzierma et al. (2012) related displacement of crustal velocity anomalies to major faults with a NW direction splitting from the N-S strike-slip LOFZ at around $39^{\circ} \mathrm{S}$, where the Valdivia FZ intersects the LOFZ. The lateral movement of the LOFZ causes transpression and the uplift of the Loncoche ridge (Dzierma et al., 2012). However, neither of the inferred faults proposed by these authors is evident, and none of them have been mapped in the geological maps of this area (Duhart et al., 2003; Quiroz et al., 2007). The Loncoche ridge is located in the low-elevation Tolten segment (Fig. 4). Plio-Pleistocene deposits near the coast reach maximum elevations of only $\sim 100$ m.a.s.l. indicating that, at these latitudes, the Coastal Cordillera was subjected to lower uplift than the Central Depression. Perhaps the subduction of the Valdivia FZ promotes underplating of subducted sediment in the Central Depression instead of the Coastal area. However, the Central Depression is not uplifted in the intersection of the Chilean margin with other oceanic fractures. New studies are therefore needed to explain the origin of this enigmatic morphostructural feature.

\section{Conclusions}

Our studies indicate the following stages on the tectono-sedimentary evolution of the forearc of south-central Chile $\left(36^{\circ} 30^{\prime}-42^{\circ} \mathrm{S}\right)$ during the late Cenozoic.

1) A regional event of extensional tectonics during the Oligoceneearly Miocene resulted in the genesis of a series of basins that extended from the present Chilean coast to the retroarc in Argentina. After a period characterized by widespread volcanism, progressive extension and crustal thinning led to a widespread marine transgression that covered most of the forearc and part of the present Andean Cordillera around $\sim 20 \mathrm{Ma}$.

2) An important phase of compressive tectonics that started at $\sim 19$ caused the deformation of the Upper Oligocene-Lower Miocene strata and older rocks, the growth of the Andean Cordillera, and the beginning of foreland sedimentation. Most of the forearc became a positive, mountainous area during the late Early-Late Miocene. Sintectonic sedimentation took place in the coastal area during this period.

3) Generation of a major reverse west verging fault in the limit between the Central Depression and the Andean Cordillera caused significant uplift of the western flank of the Andes, triggering flexural subsidence and the accumulation of coarse-grained marine and continental deposits in the forearc during the Plio-Pleistocene. These deposits filled the paleorelief generated during the previous stage.

4) The sudden increase of sediment flux to the trench caused the change from non-accretion or subduction erosion to accretion in the margin of south-central Chile. Progressive growth of the accretionary wedge gave birth to a forearc high, the Coastal Cordillera, which was uplifted in the last $2 \mathrm{Ma}$.

The cited sequence of events indicates that the forearc of southcentral Chile had a complex development related to Andean evolution in a first stage followed by accretionary processes acting exclusively in the forearc in a second stage. The forearc had a similar tectonic evolution to the Andean Cordillera during the Oligo-Miocene, including the development of extensional basins during the Oligocene-Early Miocene followed by compressional deformation during the late Early-Late Miocene. Afterward, the forearc acted as a foreland basin during the Plio-Pleistocene. The cited evolution implies that the Andean Cordillera did not grow trenchward instead of cratonward during the last 20-25 $\mathrm{Ma}$ as proposed by some authors. Uplift of the Coastal Cordillera occurred in the last $2 \mathrm{Ma}$, a process much younger than classically considered. The origin of this range is unrelated to the tectonic evolution of the Andean Cordillera, but the uplift of the western flank of this range was a fundamental process because it caused a significant increase of trench sedimentation, triggering accretion. The Central Depression is not a typical forearc basin formed by the growth of an accretionary wedge because this area was deformed and uplifted during the late Early-Late Miocene, it acted as a foreland basin during the PlioPleistocene, and margin accretion postdates forearc sedimentation.

Some segments of the forearc did not experience coastal uplift in the last 2 Ma. Their geomorphic and geological features were attained during the late Early-Late Miocene phase of compressional deformation, uplift, and erosion, and the subsequent Plio-Pleistocene deposition covering part of the Miocene paleorelief. These low-elevation areas coincide with the subduction of oceanic fracture zones because their dehydration causes the enhanced transport of fluid into the system reducing deformation of the accretionary wedge and inhibiting forearc uplift.

Because the Chilean margin extends along more than $4000 \mathrm{~km}$ and presents a marked geologic and climatic segmentation, future work should resolve whether the proposed tectono-sedimentary development for the forearc of south-central Chile was similar in other areas of this margin or if they followed a different evolution instead.

Our studies show that the genesis of the Coastal Cordillera and Central Depression of south-central Chile is complex and related to different geologic factors. The evolution of these morphostructural units during the late Cenozoic has been strongly influenced by the tectonic development of the Andean Cordillera. Whereas the genesis of Coast Ranges in other convergent margins has been typically related to accretionary processes, our work can be of help to explore the relationship between the evolution of these forearc highs and tectonic processes in the arc area.

Supplementary data to this article can be found online at https://doi. org/10.1016/j. earscirev.2020.103465.

\section{Declaration of Competing Interest}

The authors declare that they have no known competing financial interests or personal relationships that could have appeared to influence the work reported in this paper.

\section{Acknowledgments}

AE was founded by Conicyt, Fondecyt Regular projects 3060051, 11080115, and 1151146, and by the Universidad de Concepción, Chile. 
MPR was founded by Conicyt, Fondecyt project 3180710, Chile. LS was founded by ANPCyT (PICT 2016-2252), University of Buenos Aires (grant UBACYT20020150100166BA, 20020190100234BA) and CONICET (Grant 11220150100426CO), Argentina. DO work was partially funded by the project UNRNPI 40-A-631, Argentina. We thank ENAP for access to seismic and well data and Dr. María Mardónes for her advice in some geological aspects. We are grateful to Sebastian Zapata Henao, Douwe van Hinsbergen, and an anonymous reviewer for their helpful suggestions and constructive comments, which considerably improved the manuscript.

\section{References}

Adriasola, A.C., 2003. Low temperature thermal history and denudation along the Liquiñe-Ofqui fault zone in the Southern Chilean Andes, 41-42 S. Ph.D Thesis. RuhrUniversität Bochum, 119 pp.

Adriasola, A.C., Thomson, S.N., Brix, M.R., Hervé, F., Stöckhert, B., 2005. Postmagmatic cooling and late Cenozoic denudation of the North Patagonian Batholith in the Los Lagos region of Chile, $41^{\circ}-42^{\circ} 15^{\prime}$ S. Int. J. Earth Sci. 95, 501-528.

Álvarez, P., Rádic, J.P., Rojas, L., 2006. Evolución tectonosedimentaria de la cuenca de antearco Arauco-Itata. Chile central. In: XI Congreso Geológico Chileno, Antofagasta $1,21-24$.

Antinao, J.L., Duhart, P., Clayton, J., Elgueta, S., McDonough, M., 2000. Area de AncudMaullín, Región de Los Lagos. Mapa geológico no 17. Sernageomin, 1:100000 scale.

Armijo, R., Rauld, R., Thiele, R., Vargas, G., Campos, J., Lacassin, R., Kausel, E., 2010. The West Andean Thrust, the San Ramón Fault, and the seismic hazard for Santiago, Chile. Tectonics 29, TC2007.

Astini, R.A., Dávila, F.M., 2010. Comment on "the West Andean Thrust, the San Ramón Fault, and the seismic hazard for Santiago, Chile" by Rolando Armijo et al. Tectonic 29, TC4009.

Bangs, N.L., Cande, S.C., 1997. Episodic development of a convergent margin inferred from structures and processes along the southern Chile margin. Tectonics 16 (3), 489-503.

Basset, D., Watts, A.B., 2015. Gravity anomalies, crustal structure, and seismicity at subduction zones: 1 . Seafloor roughness and subducting relief. Geochem. Geophys. Geosyst. 16, 1508-1540.

Biró-Bagoczky, L., 1979. Contribución al conocimiento de la formación Tubul. Plioceno superior, provincia de Arauco ( $37^{\circ} 14^{\prime}$ Lat. Sur), Chile. In: II Congreso Geológico Chileno, Arica 3, H33-H44.

Brandon, M.T., 2004. The Cascadia subduction wedge: The role of accretion, uplift, and erosion. In: van der Pluijm, B.A., Marshak, S. (Eds.), Earth Structure. An Introduction to Structural Geology and Tectonics. W.W. Norton \& Company, Inc., New York, pp. 566-574.

Brandon, M.T., Roden-Tice, M.K., Garver, J.I., 1998. Late Cenozoic exhumation of the Cascadia accretionary wedge in the Olympic Mountains, Northwest Washington State. Geol. Soc. Am. Bull. 110 (8), 985-1009.

Brüggen, J., 1950. Fundamento de la Geología de Chile. Santiago, Chile, Instituto Geografico Militar, Santiago, 374 pp.

Campos, A., Moreno, H., Muñoz, J., Antinao, J.L., Clayton, J., Martin, M., 1998. Mapa Geológico del área Futrono-Lago Ranco, Región de los Lagos. Mapas Geológicos № 8 1:100000 scale.

Cembrano, J., Lavenu, A., Reynolds, P., Arancibia, G., López, G., Sanhueza, A., 2002 Late Cenozoic transpressional ductile deformation north of the Nazca-South America-Antarctica triple junction. Tectonophysics 354, 289-314.

Céspedes, S., Johnson, C., 1984. Cuencas sedimentarias en el Valle Central (entre Temuco y Golfo de Corcovado): Empresa Nacional del Petróleo de Chile. Report 622, $12 / 253,33$ p.

Chang, Z., Vervoort, J.D., McClelland, W.C., Knaack, C., 2006. U-Pb dating of zircon by LA-ICP-MS. Geochem. Geophys. Geosyst. 7, 1-14.

Charrier, R., Pinto, L., Rodríguez, M.P., 2007. Tectonostratigraphic evolution of the Andean orogen in Chile. In: Moreno, T., Gibbons, W. (Eds.), The Geology of Chile. The Geological Society, London, pp. 21-114.

Chen, Z., Schellart, W.P., Duarte, J.C., Strak, V., 2017. Topography of the overriding plate during progressive subduction: a dynamic model to explain forearc subsidence. Geophys. Res. Lett. 44 https://doi.org/10.1002/2017GL074672.

Clift, P., Vannucchi, P., 2004. Controls on tectonic accretion versus erosion in subduction zones: Implications for the origin and recycling of the continental crust. Rev. Geophys. 42, RG2001.

Cloos, M., Shreve, R.L., 1988. Subduction-channel model of prism accretion, melange formation, sediment subduction, and subduction erosion at convergent plate margins, 1. Background and description. Pure Appl. Geophys. 128, 456-500.

Comte, D., Farías, M., Roecker, S., Russo, R., 2019. The nature of the subduction wedge in an erosive margin: Insights from the analysis of aftershocks of the $2015 \mathrm{Mw} 8.3$ Illapel earthquake beneath the Chilean Coastal Range. Earth Planet Sc. Lett. 520, $50-62$.

Contreras-Reyes, E., Grevemeyer, I., Flueh, E.R., Reichert, C., 2008. Upper lithospheric structure of the subduction zone offshore southern Arauco Peninsula, Chile at $\sim 38^{\circ}$ S. J. Geophys. Res. 113, B07303.

Contreras-Reyes, E., Flueh, E.R., Grevemeyer, I., 2010. Tectonic control on sediment accretion and subduction off south Central Chile: Implications for coseismic rupture processes of the 1960 and 2010 megathrust earthquakes. Tectonics 29, TC6018.
Cuadra, P., 1986. Geocronologia K-Ar del yacimiento El Teniente y areas adyacentes, Rev. Geol. Chile 27, 3-26.

Dickinson, W.R., 1995. Forearc Basins, in Busby, C.J., Ingersoll, R.V. (Eds.), Tectonics of Sedimentary Basins, p. 221-261.

Dickinson, W.R., Seely, D.R., 1979. Structure and stratigraphy of forearc regions. AAPG Bull. 63, 2-31.

Duhart, P., 2008. Processos metalogenéticos em ambientes de arco magmático tipo andino, caso de estudo: mineralizações da região dos Andes patagônicos setentrionais do Chile. Ph.D Thesis, Universidade de São Paulo, 216 pp.

Duhart, P., McDonough, M., Muñoz, J., Martin, M., Villeneuve, M., 2001. El Complejo Metamórfico Bahía Mansa en la cordillera de la Costa del centro-sur de Chile (39 $\left.30^{\prime}-42^{\circ} 00^{\prime} \mathrm{S}\right)$ : geocronología K-Ar, ${ }^{40} \mathrm{Ar} /{ }^{39} \mathrm{Ar}$ y U-Pb e implicancias en la evolución del margen sur-occidental de Gondwana. Rev. Geol. Chile 28 (2) 179-208.

Duhart, P., Antinao, J., Clayton, J., Elgueta, S., Crignola, P., McDonough, M., 2003. Geologia del area Los Lagos-Malalhue. Region de Los Lagos. Serie Geología Básica $81,1: 100000$ scale.

Dzierma, I., Rabbel, W., Thorwart, M., Koulakov, I., Wehrmann, H., Hoernle, K., Comte, D., 2012. Seismic velocity structure of the slab and continental plate in the region of the 1960 Valdivia (Chile) slip maximum - Insights into fluid release and plate coupling. Earth Planet. Sc. Letters 331-332C, 164-176.

Elgueta, S., Mpodozis, S., 2012. Evolución Tectono-Sedimentaria de la Cuenca del Río Cruces (Valdivia) durante el Neógeno. XIII Congreso Geológico Chileno, Antofagasta, In, pp. 649-651.

Elgueta, S., Rubio, X., 1991. Estratigrafía del Terciario del sector occidental de la Depresión Central entre los $37^{\circ}$ y $38^{\circ} \mathrm{S}$, Chile. VI Congreso Geológico Chileno, Viña del Mar, In, pp. 723-727.

Echaurren, A, Folguera, A, Gianni, G, Orts, D., Tassara, A., Encinas, A., Gimenez, M., Valencia, V., 2016. Tectonic evolution of the North Patagonian Andes ( $\left.41^{\circ}-44^{\circ} \mathrm{S}\right)$ through recognition of syntectonic strata. Tectonophysics 677-678, 99-114.

Elgueta, S., McDonough, M., Le Roux, J., Urqueta, E., Duhart, P., 2000. Estratigrafía y sedimentología de las cuencas terciarias de la Región de Los Lagos (39-4130’S). Bol. Sernageomin 57, 1-50.

Encinas, A., Maksaev, V., Pinto, L., Le Roux, J.P., Munizaga, F., Zentilli, M., 2006. Pliocene lahar deposits in the Coastal Cordillera of Central Chile: Implications for uplift, avalanche deposits, and porphyry copper systems in the Main Andean Cordillera. J. S. Am. Earth Sci. 20, 369-381.

Encinas, A., Finger, K.L., Buatois, L.A., Peterson, D.E., 2012. Major forearc subsidence and deep-marine Miocene sedimentation in the present Coastal Cordillera and Longitudinal Depression of south-Central Chile ( $\left.38^{\circ} 30^{\prime} \mathrm{S}-41^{\circ} 45^{\prime} \mathrm{S}\right)$. Geol. Soc. Am. Bull. 124 (7/8), 1262-1277.

Encinas, A., Zambrano, P.A., Finger, K.L., Valencia, V., Buatois, L.A., Duhart, P., 2013 Implications of Deep-marine Miocene Deposits on the Evolution of the North Patagonian Andes. J. Geol. 121, 215-238.

Encinas, A., Folguera, A., Bechis, F., Finger, K.L., Zambrano, P., Pérez, F., Bernabé, P., Tapia, F., Riffo, R., Buatois, L., Orts, D., Nielsen, S.N., Valencia, V., Cuitiño, J., Oliveros, V., De Girolamo Del Mauro, L., Ramos, V.A., 2018. The Late oligocene-Early miocene marine transgression of Patagonia. In: Folguera, A., Contreras-Reyes, E., Heredia, N., Encinas, A., Iannelli, S.B., Oliveros, V., Arriagada, C. (Eds.), The Evolution of the Chilean-Argentinean Andes. Springer Earth System Sciences, Cham, pp. 443-474.

Farías, M., Charrier, R., Carretier, S., Martinod, J., Fock, A., Campbell, D., Cáceres, J., Comte, D., 2008a. Late Miocene high and rapid surface uplift and its erosional response in the Andes of central Chile $\left(33^{\circ}-35^{\circ} \mathrm{S}\right)$. Tectonics 27.

Farías, M., Charrier, R., Carretier, S., Martinod, J., Comte, D., 2006. Erosión versus tectonica en el origen de la Depresion Central de Chile Central. XI Congreso Geológico Chileno, Antofagasta 2, 201-204.

Farías, M., Carretier, S., Charrier, R., Martinod, J., Tassara, A., Encinas, A., Comte, D., 2008b. No subsidence in the development of the Central Depression along the Chilean margin. In: VII International Symposium on Andean Geodynamics (ISAG), Nice, pp. 206-209.

Farías, M., Comte, D., Charrier, R., Martinod, J., David, C., Tassara, A., Tapia, F., Fock, A., 2010. Crustal-scale structural architecture in Central Chile based on seismicity and surface geology: Implications for Andean mountain building. Tectonics 29, TC3006.

Ferraris, F., 1981. Hoja Los Angeles-Angol. Mapas geológicos preliminares de Chile no. 5, Instituto de Investigaciones Geológicas, 1:250000 scale.

Finger, K.L., 2013. Miocene foraminifera from the south-central coast of Chile. Micropaleontology 59, 341-493.

Finger, K.L., Encinas, A., 2009. Recognition and implications of globigerinathekids (Eocene planktic foraminifera) in coal-bearing successions of the forearc of southCentral Chile ( $37^{\circ} 45^{\prime}-41^{\circ} 50^{\prime}$ 'S). Ameghiniana 46 (2), 437-442.

Gana, P., Wall, P., 1997. Evidencias geocronológicas ${ }^{40} \mathrm{Ar} /{ }^{39} \mathrm{Ar}$ y K-Ar de un hiatus Cretácico Superior-Eoceno en Chile central (33-33 30'S). Rev. Geol. Chile 24 (2), $145-163$.

García, F., 1968. Estratigrafía del Terciario de Chile central. In: Cecioni, G. (Ed.), E] Terciario de Chile central. Editorial Andrés Bello, Santiago de Chile, pp. 25-57.

Gehrels, G., Valencia, V., Pullen, A., 2006. Detrital Zircon Geochronology by LaserAblation Multicollector ICPMS at the Arizona LaserChron Center. The Pal. Soc. Pap 12, 67-76.

Giambiagi, L., Tassara, A., Mescua, J., Tunik, M., Alvarez, P., Godoy, E., Hoke, G., Pinto, L., Spagnotto, S., Porras, H., Tapia, F., Jara, P., Bechis, F., García, V.H., Suriano, J., Moreiras, S.M., Pagano, S.D., 2014. Evolution of shallow and deep structures along the Maipo-Tunuyán transect $\left(33^{\circ} 40^{\prime} \mathrm{S}\right)$ : from the Pacific coast to the Andean foreland, in: Sepúlveda, S. A., Giambiagi, L. B., Moreiras, S. M., Pinto, L., 
Tunik, M., Hoke, G. D., Farías, M. (Eds.), Geodynamic Processes in the Andes of Central Chile and Argentina. Geol. Soc. Lond., Spec. Publ. 399, 63-82.

Giambiagi, L., Mescua, J., Bechis, F., Hoke, G., Suriano, J., Spagnotto, S., Spagnotto, S. Moreiras, S.M., Losada, A., Mazzitelli, M., Dapoza, R.T., Folguera, A., Mardonez, D., Pagano, D.S., 2016. Cenozoic Orogenic Evolution of the Southern Central Andes (32-36 S) in: Folguera, A., Naipauer, M., Sagripanti, L., Ghiglione, M.C., Orts, D., Giambiagi, L. (Eds.), Growth of the Southern Andes. Springer, London, pp. 63-98.

Glodny, J., Gräfe, K., Echtler, H., Rosenau, M., 2008. Mesozoic to Quaternary continenta margin dynamics in south-Central Chile $\left(36-42^{\circ} \mathrm{S}\right)$ : the apatite and zircon fission track perspective. Int. J. Earth Sci. 97, 1271-1291.

González, E., 1983. Geological and Geophysical Information for Risk Contracts: Empresa Nacional del Petroleo de Chile. Internal Report. 205 p.

González, F., Maksymowicz, A., Díaz, D., Villegas, L., Leiva, M., Blanco, B., Vera, E. Contreras, S., Cabrera, Daniel, Bonvalot, S., 2018. Characterization of the depocenters and the basement structure, below the Central Chile Andean Forearc: a 3D geophysical modelling in Santiago Basin area. Basin Res. 30, 799-815.

Guillaume, B., Moroni, M., Funiciello, F., Martinod, J., Faccenna, C., 2010. Mantle flow and dynamic topography associated with slab window opening: Insights from laboratory models. Tectonophysics 496, 83-98.

Hackney, R.I., Echtler, H.P., Franz, G., Gotze, H.J., Lucassen, F., Marchenko, D., Melnick, D., Meyer, U., Schmidt, S., Tasarova, Z., Tassara, A., Wienecke, S., 2006. The segmented overriding plate and coupling at the south-central Chilean margin (36-42 ${ }^{\circ}$ S). In: Oncken, O., Franz, G., Giese, P., Götze, H.J., Ramos, V., Strecker, M. Wigger, P. (Eds.), The Andes: Active Subduction Orogeny. Springer-Verlag, Berlin, pp. 355-374.

Haq, B., Hardenbol, J., Vail, P., 1987. Chronology of fluctuating sea levels since the Triassic. Science 235, 1156-1167.

Hassani, R., Jongmans, D., Chéry, J., 1997. Study of plate deformation and stress in subduction processes using two-dimensional numerical models. J. Geophys. Res. 102 (B8), 17951-17965.

Hauser, A., 1986. Los Rodados Multicolores: su distribución y características en el sur de Chile. Rev. Geol. Chile 27, 69-83.

Hervé, F., 1994. The southern Andes between $39^{\circ}$ and $44^{\circ} \mathrm{S}$ latitude: The geological signature of a transpressive tectonic regime related to a magmatic arc. In: Reutter, $\mathrm{K}$. J., Scheuber, E., Wigger, P. (Eds.), Tectonics of the Southern Central Andes. SpringerVerlag, Berlin, pp. 243-248.

Horton, B., 2018. Tectonic Regimes of the Central and Southern Andes: responses to Variations in Plate Coupling during Subduction. Tectonics 37, 402-429.

Horton, B.K., Fuentes, F., 2016. Sedimentary record of plate coupling and decoupling during growth of the Andes. Geology 44 (8), 647-650.

Illies, H., 1970. Geología de los alrededores de Valdivia y volcanismo y tectónica en márgenes del Pacífico en Chile meridional. Instituto de Geología y Geografía. Universidad Austral, Valdivia, 64 pp.

Jarvis, A., Reuter, H.I., Nelson, A., Guevara, E., 2008. Hole-filled SRTM for the globe Version 4, available from the CGIAR-CSI SRTM 90m Database. http://srtm.csi.cgiar. org.

Jordan, T.E., Isacks, B.L., Allmendinger, R.W., Brewer, J.A., Ramos, V.A., Ando, C.J., 1983. Andean tectonics related to geometry of subducted Nazca plate. Geol. Soc. Am. Bull. 94, 341-361.

Jordan, T., Matthew, W., Veiga, R., Pángaro, F., Copeland, P., Kelley, S., Mpodozis, C., 2001. Extension and basin formation in the southern Andes caused by increased convergence rate: A mid-Cenozoic trigger for the Andes. Tectonics 20, 308-324.

Kaizuka, S., Matsuda, T., Nogami, M., Yonekura, N., 1973. Quaternary tectonic and recent seismic crustal movements in the Arauco Peninsula and its environs, centra Chile. Geographical Report, vol. 8. Tokyo Metropolitan University, Tokyo, pp. 1-49.

Kendrick, E., Bevis, M., Smalley, R., Brooks, B., Vargas, R., Lauría, E., Fortes, L., 2003. The Nazca-South America Euler vector and its rate of change. J. S. Am. Earth Sci. 16, $125-131$.

Kukowski, N., Oncken, O., 2006. Subduction erosion, the "normal mode of fore-arc material transfer along the Chilean margin?”. In: Oncken, O., Chong, G., Franz, G., Giese, P., Götze, H.J., Ramos, V., Strecker, M., Wigger, P. (Eds.), The Andes-Active Subduction Orogeny. Springer-Verlag, Berlin-Heidelberg, pp. 217-236.

Lange, D., Rietbrock, A., Haberland, C., Bataille, K., Dahm, T., Tilmann, F., Flüh, E.R., 2007. Seismicity and geometry of the south Chilean subduction zone (41.5 $\left.\mathrm{S}-43.5^{\circ} \mathrm{S}\right)$ : Implications for controlling parameters. Geophys. Res. Lett 34, L06311.

Lavenú, A., Cembrano, J., 1999. Compressional- and transpressional-stress pattern for Pliocene and Quaternary brittle deformation in fore arc and intra-arc zones (Andes of Central and Southern Chile). J. Struc. Geol. 21, 1669-1691.

Lohrmann, J., Kukowski, N., Krawczyk, C.M., Oncken, O., Sick, C., Sobiesiak, M., Rietbrock, A., 2006. Subduction channel evolution in brittle fore-arc wedges: A combined study with scaled sandbox experiments, seismological and reflection seismic data and geological field evidence. In: Oncken, O., Franz, G., Giese, P., Götze, H.J., Ramos, V., Strecker, M., Wigger, P. (Eds.), The Andes: Active Subduction Orogeny. Springer-Verlag, Berlin, pp. 237-262.

Ludwig, K.R., 2003. Isoplot 3.0-A geochronological toolkit for Microsoft Excel. Special publication No. 4, Berkeley Geochronology Center, 71 pp.

Maksaev, V., Munizaga, F., Zentilli, M., Charrier, R., 2009. Fission track thermochronology of Neogene plutons in the principal Andean Cordillera of Centra Chile (33-35 degrees S): implications for tectonic evolution and porphyry Cu-Mo mineralization. And. Geol. 36, 153-171.

Maksymowicz, A., 2015. The geometry of the Chilean continental wedge: Tectonic segmentation of subduction processes off Chile. Tectonophysics 659, 183-196.

McDonough, M., Duhart, P., Crignola, P., 1997. Naturaleza del alzamiento del basamento costero y la apertura de la cuenca Osorno-Llanquihue. X Región: Nuevos antecedentes sísmicos y observaciones de terreno. In: VIII Congreso Geológico Chileno, Antofagasta 1, 164-168.

Mella, M., Quiroz, D., 2010. Geología del área Temuco-Nueva Imperial, región de la Araucanía. Serie Geología Básica no. 122, Sernageomin, 1:100000 scale.

Mella, M., Duhart, P., McDonough, M., Antinao, J.L., Elgueta, S., Crignola, P., 2012. Geología del área Valdivia-Corral. Región de los Ríos. Carta Geológica de Chile no. 137, Sernageomin, 1:100000 scale.

Melnick, D., Echtler, H.P., 2006. Inversion of forearc basins in south-Central Chile caused by rapid glacial age trench fill. Geology 34, 709-712.

Melnick, D., Charlet, F., Echtler, H.P., De Batist, M., 2006. Incipient axial collapse of the Main Cordillera and strain partitioning gradient between the central and Patagonian Andes, Lago Laja, Chile. Tectonics 25, TC5004.

Melnick, D., Bookhagen, B., Strecker, M.R., Echtler, H.P., 2009. Segmentation of megathrust rupture zones from fore-arc deformation patterns over hundreds to millions of years, Arauco peninsula, Chile. J. Geophys. Res. 114, B01407.

Mercer, J.H., 1976. Glacial history of Southernmost South America. Quat. Res. 6, $125-166$.

Moreno, M., Melnick, D., Rosenau, M., Bolte, J., Klotz, J., Echtler, H., Baez, J., Bataille, K., Chen, J., Bevis, M., Hase, H., Oncken, O., 2011. Heterogeneous plate locking in the South-Central Chile subduction zone: building up the next great earthquake. Earth Planet. Sci. Lett. 305, 413-424.

Moreno, M., Haberland, C., Oncken, O., Rietbrock, A., Angiboust, S., Heidbach, O., 2014. Locking of the Chile subduction zone controlled by fluid pressure before the 2010 earthquake. Nat. Geosci. 7, 292-296.

Moreno, M., Li, S., Melnick, D., Bedford, J.R., Baez, J.C., Motagh, M., Metzger, S. Vajedian, S., Sippl, C., Gutknecht, B.D., Contreras-Reyes, E., Deng, Z., Tassara, A., Oncken, O., 2018. Chilean megathrust earthquake recurrence linked to frictional contrast at depth. Nat. Geosci. 11, 285-290.

Mpodozis, C., Ramos, V.A., 1989. The Andes of Chile and Argentina. In: Ericksen, G.E., Cañas, M.T., Reinemund, J.A. (Eds.), Geology of the Andes and its Relation to Hydrocarbon and Mineral Resources, Circum-Pacific Council for Energy and Mineral Resources. Earth Sci. Ser, vol. 11, pp. 59-90.

Muñoz, J., Troncoso, R., Duhart, P., Crignola, P., Farmer, L., Stern, C.R., 2000. The relation of the mid-Tertiary coastal magmatic belt in south-Central Chile to the late Oligocene increase in plate convergence rate. Rev. Geol. Chile 27, 177-203.

Muñoz-Cristi, J., 1960. Contribución al conocimiento geológico de la Cordillera de la Costa de la Zona Central. Minerales 15 (69), 28-46.

Nielsen, S.N., Glodny, J., 2009. Early Miocene subtropical water temperatures in the Southeast Pacific. Palaeogeogr. Palaeoclimatol. Palaeoecol. 280, 480-488.

Niemeyer, H., Muñoz, J., 1983. Geología de la Hoja Laguna de la Laja. Carta Geológica de Chile no. 57, Sernageomin, 1:250000 scale.

Oliveros, V., Vásquez, P., Creixell, C., Lucassen, F., Ducea, M.N., Ciocca, I., González, J., Espinoza, M., Salazar, E., Coloma, F., Kasemann, S.A., 2019. Lithospheric evolution of the Pre- and early Andean convergent margin. Chile. Gondwana Res. 80, 202-227.

Orts, D.L., Folguera, A., Encinas, A., Ramos, M., Tobal, J., Ramos, V.A., 2012. Tectonic development of the North Patagonian Andes and their related Miocene foreland basin $\left(41^{\circ} 30^{\prime}-43^{\circ} \mathrm{S}\right)$. Tectonics 31 , TC3012.

Paces, J., Miller, J., 1993. Precise U-Pb ages of Duluth complex and related mafic intrusions, northeastern Minnesota; geochronological insights to physical, petrogenetic, paleomagnetic, and tectonomagmatic processes associated with the 1.1 Ga midcontinent rift system. J. Geophys. Res. 98 (B8), 13997-14013.

Paton, C., Woodhead, J.D., Hellstrom, J.C., Hergt, J.M., Greig, A., Maas, R., 2010 Improved laser ablation U-Pb zircon geochronology through robust downhole fractionation correction. Geochem. Geophys. Geosyst 11 (3). Q0AA06.

Pino, M., Moreno, K., Riedemann, M.P., 2002. La terraza del último interglacial en la costa de Valdivia: observaciones, interpretaciones y desafios. In: Simposio Internacional de Geología Ambiental para Planificación del Uso del Territorio, Puerto Varas, pp. 165-168.

Porter, S., 1981. Pleistocene glaciation in the southern Lake District of Chile. Quat. Res. 16, 263-292.

Quiroz, D., Duhart, P., Crignola, P., 2007. Geología del área Lanco-Loncoche. Regiones de la Araucanía y los Ríos. Carta Geológica de Chile no. 106, Sernageomin, 1:100000 scale.

Rabassa, J., 2008. Late Cenozoic Glaciations in Patagonia and Tierra del Fuego. In: Rabassa, J. (Ed.), Late Cenozoic of Patagonia and Tierra del Fuego, Developments in Quaternary Sciences, Elsevier, Amsterdam, vol. 11, pp. 151-204.

Rehak, K., Strecker, M.R., Echtler, H.P., 2008. Morphotectonic segmentation of an active forearc, $37^{\circ}-41^{\circ}$ S, Chile. Geomorphology 94, 98-116.

Rodríguez, M.P., Aguilar, G., Urresty, C., Charrier, R., 2014. Neogene landscape evolution in the Andes of north-Central Chile between 28 and $32^{\circ} \mathrm{S}$ : interplay between tectonic and erosional processes, in: Sepúlveda, S. A., Giambiagi, L. B., Moreiras, S. M., Pinto, L., Tunik, M., Hoke, G. D., Farías, M. (Eds.), Geodynamic Processes in the Andes of Central Chile and Argentina. Geol. Soc. Esp. Pub. London $399,419-446$.

Rojas, C., 2000. Edad y paleoecología de la secuencia basal de la Formación Tubul: Plioceno de Arauco, mediante el análisis de foraminíferos. Universidad de Concepción, Undergraduate Thesis, 109 pp.

Rojas Vera, E.A., Mescua, J., Folguera, A., Becker, T.P., Sagripanti, L., Fennell, L. Orts, D., Ramos, V.A., 2015. Evolution of the Chos Malal and Agrio fold and thrust belts, Andes of Neuquén: Insights from structural analysis and apatite fission track dating. J. S. Am. Earth Sci. 64 (2), 418-433.

Rubio, X., 1990. Geología regional y estratigrafía del Terciario de la cuenca de Labranza, IX Región, Chile. II Simposio sobre el Terciario de Chile, Concepción, In, pp. 285-295. 
Schmitz, M.D., Bowring, S.A., 2001. U-Pb zircon and titanite systematics of the fish Canyon Tuff: an assessment of high-precision U-Pb geochronology and its application to young volcanic rocks. Geochim. Cosmochim. Ac. 65, 2571-2587.

Sepúlveda, T., Cortés-Aranda, J., Melnick, D., Astudillo, L., Vega, A., Poblete, C., 2019. Neotectónica y paleosismología del Cabalgamiento Andino Occidental (WAT) en la Región del Maule, Chile central $\left(36^{\circ} \mathrm{S}\right)$. XII Congreso Chileno de Sismología e Ingeniería Sísmica. Valdivia, In, pp. 1-15.

Sernagemin, 2003. Mapa Geológico de Chile, scale 1:1,000,000.

Sernageomin, 1998. Estudio geológico-económico de la X Región norte. Sernageomin Report IR-15-98, 6 volumes, 27 maps.

Sláma, J., Košler, J., Condon, D.J., Crowley, J.L., Gerdes, A., Hanchar, J.M., Horstwood, M.S.A., Morris, G.A., Nasdala, L., Norberg, N., Schaltegger, U. Schoene, B., Tubrett, M.N., Whitehouse, M.J., 2008. Plešovice zircon-a new natura reference material for U-Pb and Hf isotopic microanalysis. Chem. Geol. 249, 1-35.

Somoza, R., 1998. Updated Nazca (Farallon)-South America relative motions during the last 40 Myr: Implications for mountain building in the central Andean region. J. S. Am. Earth Sci. 11, 211-215.

Spikings, R., Dungan, M., Foeken, J., Carter, A., Page, L., Stuart, F., 2008. Tectonic response of the central Chilean margin $\left(35-38^{\circ} \mathrm{S}\right)$ to the collision and subduction of heterogeneous oceanic crust: a thermochronological study. J. Geol. Soc. Lond. 165, 941-953.

Stiefel, J., 1968. Sedimentological Reconnaissance of some Quaternary Deposits of Central and Southern Chile. University of Utah Press, Congress International Association for Quaternary Research, pp. 559-576.

Stinnesbeck, W., 1986. Zu den faunistischen und palökologischen Verhältnissen in der Quriquina Formation (Maastrichtium) Zentral-Chiles. Palaeontogr. 194, 99-237.

Suárez, M., Emparán, C., 1997. Hoja Curacautín. Regiones de la Araucanía y del Biobio. Carta Geológica de Chile no. 71, Sernageomin, 1:250000 scale.

Tašárová, Z.A., 2007. Towards understanding the lithospheric structure of the southern Chilean subduction zone $\left(36^{\circ} \mathrm{S}-42^{\circ} \mathrm{S}\right)$ and its role in the gravity field. Geophys. J. Int 170, 995-1014.

Thiele, R., Moreno, M., Elgueta, S., Lahsen, A., Rebolledo, S., Petit-Breuilh, M.E., 1998. Evolución geológico-geomorfológica cuaternaria del tramo superior del valle del río Laja. Rev. Geol. Chile 25 (2), 229-253.
Thomson, N., 2002. Late Cenozoic geomorphic and tectonic evolution of the Patagonian Andes between latitudes $42^{\circ} \mathrm{S}$ and $46^{\circ} \mathrm{S}$ : an appraisal based on fission-track results from the transpressional intra-arc Liquiñe-Ofqui fault zone. Geol. Soc. Am. Bull. 114, 1159-1173.

Thomson, S., Brandon, M., Tomkin, J., Reiners, P.W., Vásquez, C., Wilson, N.J., 2010. Glaciation as a destructive and constructive control on mountain building. Nature 467, 313-317.

Thornburg, T.M., Kulm, L.D., Hussong, D.M., 1990. Submarine fan development in the southern Chile trench: a dynamic interplay of tectonics and sedimentation. Geol. Soc. Am. Bull. 102, 1658-1680.

Valencia, V.A., Ruiz, J., Barra, F., Geherls, G., Ducea, M., Titley, S.R., Ochoa-Landín, L., 2005. U-Pb zircon and Re-Os molybdenite geochronology from La Caridad porphyry copper deposit: insights for the duration of magmatism and mineralization in the Nacozari District, Sonora. Mexico. Miner. Deposita. 40, 175-191.

Valenzuela, E.A., 1982. Estratigrafía de la boca occidental del canal de Chaco, X Región, Chile. In: III Congreso Geológico Chileno, Concepción, pp. A343-A376.

Vargas, C., 2019. Análisis de las concentraciones fósiles de la Formación Tubul (PlioPleistoceno), provincia de Arauco, región del Biobío, Chile. Universidad de Concepción, Undergraduate Thesis, 164 pp.

Vergara, M., Munizaga, F., 1974. Age and evolution of the Upper Cenozoic andesite volcanism in central-South Chile. Geol. Soc. Am. Bull. 85, 603-606.

Vergara, M., Moraga, J., Zentilli, M., 1997. Evolución termotectónica de la cuenca terciaria entre Parral y Chillán: análisis por trazas de fisión en apatitas. In: VIII Congreso Geológico Chileno, Antofagasta, S6, pp. 1574-1578.

Von Huene, R., Scholl, D.W., 1991. Observations at convergent margins concerning sediment subduction, subduction erosion, and the growth of continental crust. Rev. Geophys. 29, 279-316.

Williams, I.S., 1998. U-Th-Pb geochronology by ion microprobe. Rev. Econ. Geol. 7, $1-35$.

Yáñez, G., Muñoz, M., Flores-Aqueveque, V., Bosch, A., 2015. Gravity derived depth to basement in Santiago Basin, Chile: implications for its geological evolution, hydrogeology, low enthalpy geothermal, soil characterization and geo-hazards. And. Geol. 42 (2), 147-172.

Yang, T., Gurnis, M., Zahirovic, S., 2016. Mantle-induced subsidence and compression in SE Asia since the early Miocene. Geophys. Res. Lett. 43, 1901-1909. 